\title{
THE EFFECT OF SKIP-GRADING ON STABILITY OF SOIL-AGGREGATE MIXTURES
}

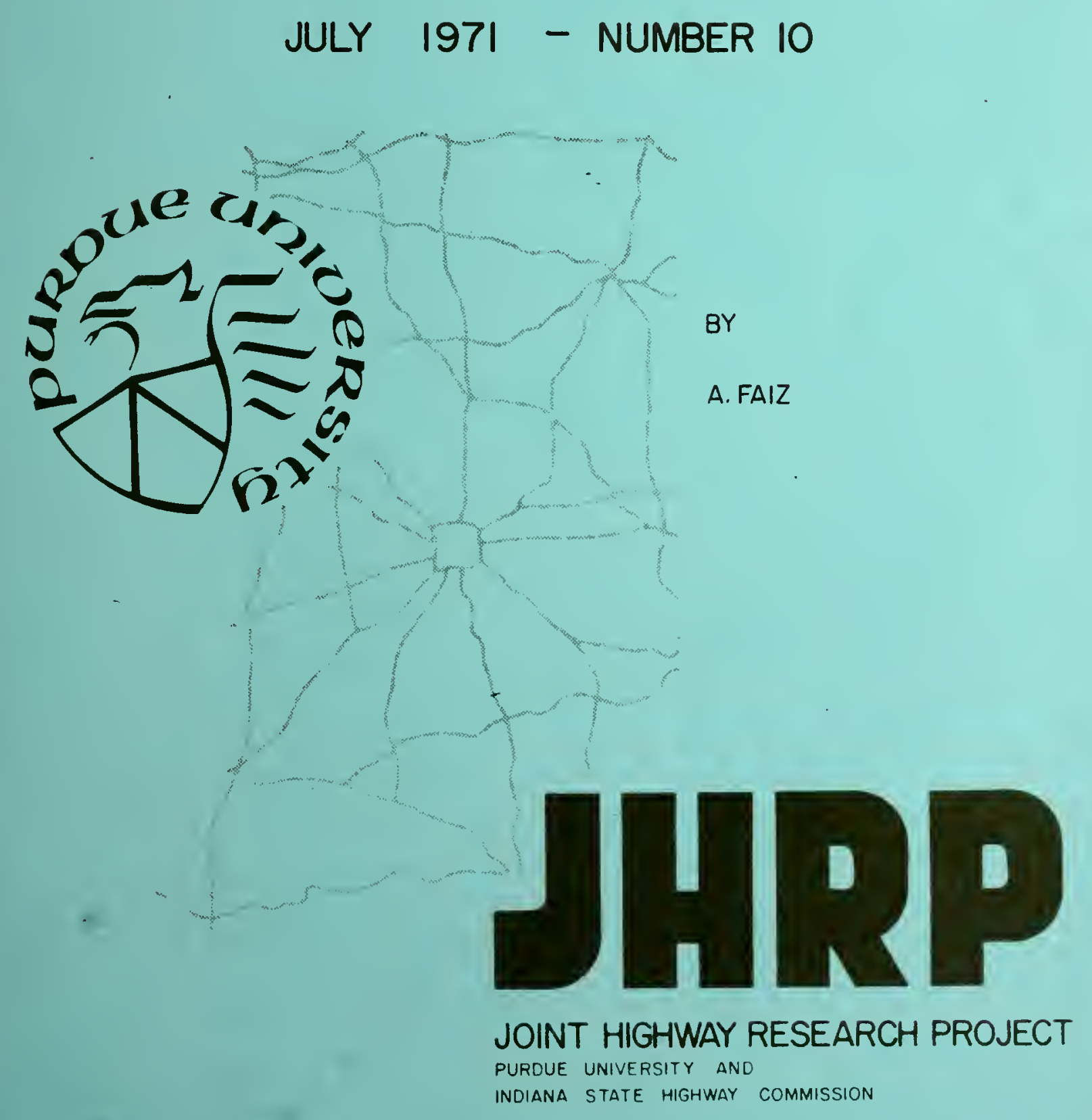



THE EFTECW OF SKIP-GRADING ON SWABILITY OF SOIL-AGGREGATE MIXIURAS

TO: J. F. McIaugh Iin, Director Joint Highway Research Project

FROH: Harold I. Michael, Associate Dinector Joint Highway Research Froject

$$
\text { JuIy 7. } 1972
$$

InIJe No.: 6 18-9

Projec돈 Noo: $\quad c-36-45 \mathrm{~J}$

Whe gttached Final Report titiled "The Hfifect of Skip-Gradiug on Stability or Soil-Aggregate Mixtures ${ }^{\text {Is }}$ is subritted ror acceptance as fulpilling the objectives of the Plan of Stucy of the same title approved by the Advisory Bcard on $150 v e$ inez 18,1969 . The report has been authored by the investigator on the researet. Br. Asif raiz, Graduate Assistant in Research on our state. Frofessor R. J. Toder served as director of the research project.

The results of the investigation are presented in may charts and tables that show in detail the effect of the variation of the material between the No, 30 and NO. 200 sieves on stabilitity parameters. The conclusions suggest limiting values of dust ratio and percent passing the No. 30 sieve for soil aggregate mixtures with low plasticity rines and compacted to standard AASHO density。

The project was totally JIFP Pinanced. Corments on the report and reports of any application of the findings by the ISHC would be appreciated.

Halins

Respectfully submitted,

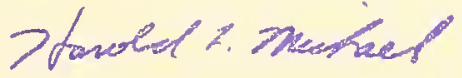

Harold Is Michael. Associate Director cc: F。 I. Ashoaucher

W. Is. Dolch

W. F. Goetz

W. I. Grecco

M. J. Gutzwizler

G。 K. Hallocis
M. E. Fer.

R. H. Harreli.

R. L. Hay:s

E。M。政ki江

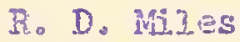

J. W。 nisizer
C. F. Scholer

M. B. Scott

W. T. Spencer

N.W. Steinkamp

H. R. J. Walsh

K. B. Hooas

E. I. Yoder 
Digitized by the Internet Archive in 2011 with funding from

LYRASIS members and Sloan Foundation; Indiana Department of Transportation 
Final Report

PHE EFFECT OF SREP-GPADING ON STABIEITY

OF SOII-AGGREGA FE MIYUTHES

by

Asito Faiz

Graduate Assistant in Ressearcin

Joint Highway Reseaxch Froject

File: $6-18-9$

Project: $\quad c-36-45 j$

Puräue University

tratayette, Indiand

JuIy 7,1971 
ACKNCWLEDGENENTS

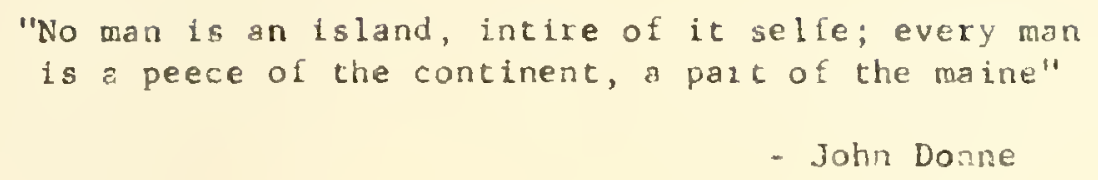

The author wishes to express his deep gratitude to Professor E. J. Yoder lor his moral support, guidance and encouragement in the conduct of this research, and for his critical review of the manuscript; to professor I. W. Burr for his advice on statistical procedures and review of the manuscript; and to Professor H. L. Michael tor his review of the manuscript.

The financlal support of this research trom the Joint Highway Research Project and Purdue University is duly acknowledged.

The author is indebted to Dr. and Mrs. R. Kapil, whose trmely financial help made it possible for him to come to Purdue University. Acknowledgement is made of the help rendered in the course of the research by Messts. Gale Orem, Glen Luetkemier, and Steve Smith, and thanks are extended to Mr. Joe Austin for his comments on the statistical analysis.

Appreciation is due to Mrs. Linda Muench for the typing of the manuscript. 
TABLE OF CONTENTS

Pege

LIST OF TABLES ....................... . v v

LIST OF FIGURES. . . . . . . . . . . . . . . . . . vil

ABSTRACT .......................... . vi11

INTRODUCTION . . . . . . . . . . . . . . . . 1

Background for this Research. . . . . . . . . 2

PURPOSE AND SCORE. . . . . . . . . . . . . . . . 5

REVIEW OF LITERATURE . . . . . . . . . . . . . 6

General Properties of Soll-Aggregate Mixtures... . 6

Effect of Flnes. . . . . . . . . . . . 6

Effect of Crushed Materlal .......... 9

Effect of Plasticity ............. 10

Permeablitty .................. 11

Intrusion. . . . . . . . . . . . . . 12

Effect of Skip-Grading . . . . . . . . . . 13

Specifications for Soll-Aggregate Mixtures. . . . . . 14

EXPERIMENTAL PROGRAM ................. 19

Materialo . . . . . . . . . . . . . 24

Evaluated Varíables................ 27

Design of Experiments.............. . . 28

CBR Tests............. . . 29

Texas Triaxial Tests.......... . . 30

Permeability Tests............ 31

TEST PROCEDURES. . . . . . . . . . . . . . . . 32

Preparation of Materials. . . . . . . . . 32

Atterberg Limits Tests................ 33

Compaction Tests................. 33

California Bearing Ratio Test......... 34

Texas Triaxial Test.............. 34

Permeability Test.............. 35 
TABLE OF CONTENTS (Continued)

Page

RESULTS . . . . . . . . . . . . . . . . . 37

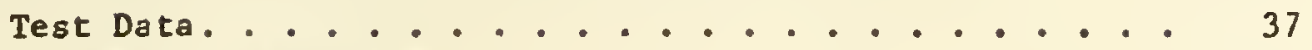

Statistical Analysis................ . 37

CBR Teat Data............ . . . 37

Texas Triaxial Test Data............ 58

INTERPRETATION OF RESULTS . . . . . . . . . . . . 68

CBR Tests. . . . . . . . . . . . . 68

Texes Triaxial Tests... . . . . . . . . . 77

Permeability Tests.................. 81

A Study of the Interaction of Plasticity and Skip-

Grading on Strength Characteristics . . . . . 85

CONCLUSIONS . . . . . . . . . . . . . . . . . 88

Genera1. . . . . . . . . . . . . . . 88

Effect of Skip-Grading Between the No. 30 and
No. 200 Sieves. . . . . . . . . . 90

BIBLIOGRAPHY. . . . . . . . . . . . . . . . . . 94

APPENDIX A. TEST DATA. . . . . . . . . . . . . 96

APPENDIX B. EQUATIONS OF BEST FIT FOR CBR TEST DATA. . . . 101 
1. Physical Requirements for Flexible Base Material . 17

2. Specifications for Indiana Size No. 53 Aggregate . 19

3. Grain Size Distribution of Test Mixtures . . . . . 25

4. Plasticity Characteristics of Various Types

of Fines............... 2 26

5. Summary of CBR Test Data........... . 40

6. Tabulation of CBR Means and Ranges......... 41

7. Summary of Analysis of Variance - CBR. . . . . . 45

8. Summary of One-Way Analysis of Variance - CBR. . . 49

9. Summary of Texas Triaxial Test Data. . . . . . . 60

10. Summary of Analysis of Variance - Triaxial Compressive Strength at 15 psi Lateral Pressure...... 61

11. Summary of Analysis of Variance - Angle of Internal Friction................ 61

12. Summary of Texas Triaxial Test Data......... 64

13. Summary of Analysis of Variance - Triaxial Compressive Strength at 15 psi Lateral Pressure...... 65

14. Sumary of Analysis of Variance - Angle of Internal Friction................ 65

15. Variation of California Bearing Ratio With Dust Ratio for Soil-Gravel Mixtures ......... 74

16. Variation of California Bearing Ratio With Dust Ratio for Soll-Crushed Stone Mixtures. . . . . . 75 


\section{LIST OF TABLES (Continued)}

Table

Page

17. Variation of Triaxial Compressive Strength and Angle of Internal Friction With Percent Retained Between No. 30 and No. 200 Sieves (5\% Passing No. 200 Sleve) . . . . . . . . . . . .

18. Variation of Triaxial Compressive Strength and Angle of Internal Friction With Percent Retained Between No. 30 and No. 200 Sieves (10\% Passing No. 200 Sieve)............... 79

19. Typical Permeability Values for Solls........ 82

20. Limiting Values of Dust Ratio and Percent Passing the No. 30 Mesh Sieve for the Tested Soll-Aggregate Mixes With Low PI Fines and Compacted to Standard AASHO Density. . . . . . . . . . . . . . .

Append is

Table

A-1. Compaction Test Data for CBR Tests........ 96

A-2. California Bearing Ratio and Consistency Limits Test Data................ . . 97

A-3. Compaction Test Data for Texss Trlaxial Tests.... 98

A-4. Texas Triaxial and Consistency Limfts Test Data... 99 A-5. Permeabilit́̄y Test Data............ 100 B-1. Equations of Best Fit for CBR Test Data....... 101 


\section{LIST OF FIGURES}

Figure

$\underline{\text { Page }}$

1. Physical States of Soil-Aggregate Mixtures ..... 7

2. Indiana Size No. 53 Coarse Aggregate Compared With

Maximum Density Grading for $n=0.5$ and $D=l^{\prime \prime} . .21$

3. Grain Size Distribution of Test Mixtures With 5

Percent Passing No. 200 Sleve. . . . . . . . 22

4. Grain Size Distribution of Test Mixtures With 10

Percent Passing No. 200 Sieve. . . . . . . . 23

5. Plot of Cell Means vs. Ranges of CBR Values

Within the Cells............. 43

6. Variation of California Bearing Ratio With Percent

Retained Between No. 30 and No. 200 Sieves . . . 69

7. Variation of California Bearing Ratio With Percent

. Retained Between No. 30 and No. 200 Sieves.... 70

8. Variation of Permeability With Percent Retained

Between No. 30 and No. 200 Sieves......... 83 


\section{ABSTRACT}

Faiz, Asif. MSCE, Purdue University, June 1971. THE EFFECT OF SKIP-GRADING ON STABILITY OF SOIL-AGGREGATE MLXTURES. Ma jor Professor: E. J. Yoder.

"What everybody echoes or in silence passes by as true todsy may turn out to be a falsehood tomorrow, mere smoke of opinion, which some had trusted for a cloud that would sprinkle fertilizing rain on their flelds. What old people say you cannot do, you try and find that you can"

- Henry David Thoreau

Two maln considerations govern the design of pavements. The first Involves the design of a physical structure, that is capable of sustaining the applled loads. The second aspect of the problem is concerned with the design of materials that constitute the pavement structure. This investigation involves the latter aspect of the design.

Soil-aggregate mixtures are commonly used as base materlal under flexible and rigid pavements. This study evaluated the effect of varying the amount of moterial retained between the No. 30 and No. 200 sieves on the stablitity of soll-aggregate mixtures. For the extreme case, the test mixtures were completely devoid of materisl between the No. 30 and No. 200 sieves.

The study was confined to moterials that conform essentially to Indiana specification No. 53 aggregate. The testing program included both gravel and crushed stone mixtures. A number of different soil 
binders (material passing the No. 200 sieve) were used. These binders were classified as non-plastic, low plastlc and high plastic tines.

To evaluate the effect of the material retained between the No. 30 and No. 200 sieves on the stability of various aggregatesoll binder combinations used in this study, the following tests were used:

1. Atterberg Iimits tests;

2. Compaction tests;

3. $\mathrm{CBR}$ test;

4. Texas trioxial compression test;

5. Permeability test.

The test data were analyzed ststiatically using analysis of variance techniques. It was determined that the varistion of material between the No. 30 and No. 200 sieves had an important bearing on the stability of the soil-aggregate mixtures. This effect, however, was influenced by the quantity of fines present in the mixtures and the plasticity characteristics of the fines.

The results of this investigation are presented in the form of graphs and tables that show in detail the effect of the variation of the materlal between the No. 30 and No. 200 sieves on stability parameters. The conclusions suggest limiting values of dust ratio, and percent passing the No. 30 mesh sieve for the soil-aggregate mixtures with low plasticity fines and compacted to standard AASHO density. 


\section{INTRODUCTION}

Paving engineers are concerned with two broad aspects of pavement design. The first is thickness design of a physical structule which is capable of sustaining the applied load. Design concepts for this are, for the most part, empirical; however, certain theoretical considerations can be used.

The second phase of the problem is concerned with the design of the materials with which the pavement will be built. Performance surveys have shown that type and quality of the base, for example, influence to a great extent the behavior of a pavement.

It is important to note that the above two design phases are interrelated and that it ia difficult to separate these during the analysis of any particular problem. Also, it is necessary to consider many factors in the design of bases and subbases, including climate, position of the grade line, drainage characteristics of the subgrade, and many other factors.

In addition to the above, it is necessary to distinguish between the primary purposes for using bases and subbases under flexible pavements as compared to the use of the same materials under rigid pavements. For flexible pavements, the primary conaideration is structural adequacy of the base and subbase layers whereas for rigid pavements, bases are used primarily for control of pumping and to provide a working platform on which to build the pavement. 
For reason of economy and because of the growing scarcity of high quality aggregates, it is necessary to make as much use as posible of aggregates that do not require a great deal of processing. It is important to note, however, that for high type pavements it is false economy to permit deviation from specifications of base course materials since maintenance costs arising from the use of poor quality materials can be extremely high.

One approach to setting specifications for base aggregate would be to adopt a certain speciflcation for bases under rigid pavements and another specification for bases under flexible pavements. Likewise, it would be possible to develop specifications for gravel bases and subbases, and another specification for crushed stone bases. From a practical point of view, however, this philosophy could cause complications from the point of view of production and control of the materia1. Hence, it is desirable, if at all possible, to develop specifications that can be applied to a variety of conditions.

\section{Background for This Research}

The standard specifications for the Indiana State Highway Commission $(13)^{*}$ set forth grading and plasticity requirements for bases and subbases used in the construction of pavements in Indlana. Particularly, reference is made here to the specification for size No. 53 aggregate, which establishes grading and plasticity requirements for granular materials irrespective of whether they be made from gravel or crushed stone. These specifications were established on the basis

\footnotetext{
* Numbers in parentheses refer to references ligted in the bibllography.
} 
of experience within the state of Indiana and have given satisfactory results.

Some aggregate producers in Indiana have found it difficult to meet the specifications for No. 53 aggregate in certain cases. For example, the specification requirea that the amount of material passing the No. 30 sieve shall lie between 15 and 30 percent and the amount passing the No. 200 mesh sieve should lie between 5 and 10 percent. In addition to the above requirements, the specification states that the fraction passing the 200 sieve shall not exceed $2 / 3$ of the fraction passing the No. 40 sieve, the liquid limit of the fraction passing the No. 40 sieve shall not exceed 25 percent (except if slag is used it shall not exceed 35 percent) and the plasticity index shall not exceed 5 percent.

It has been auggested by some producers to deviate from the percentage requirements as specifled for the No, 30 sieve. Specifically, it has been proposed to lower the minimum requirements of material passing the No. 30 sieve. In the extreme case, for example, if the lower limit of material passing the No. 30 sieve should be reduced to 10 percent and the maximum amount permitted passing the No. 200 sleve is kept at 10 percent, this would mean that the mix would have no material retained between the No. 30 and No. 200 sieves. After an extensive review of the literature, it was determined that there is little factual information on the effect of the amount of material retained between the No. 30 and No. 200 sieves on the stability of soll-aggregate mixtures. Consequently, this research was developed to investigate the effect of skip-grading on the 
stabilicy of soil-aggregate mixtures with particular emphasts on the effect of the amount of materlal retained between the No. 30 and No. 200 sieves on the properties of the $m 1 x$. 
PURPOSE AND SCOPE

The primaly objective of this study was to invegtigate the effect of varylng the amount of meterial retalned between the No, 30 and No. 200 sleves on stabllity of both gravel and crushed stone mixtures. Along with this, it was a further purpose to study the effect of plasticity and the interrelationship of plasticity and the material retained between the No. 30 and No. 200 sieves on stability.

The study was confined to materlals that conform essentially to Indiana specification No. 53 aggregate.

The scope of this study included investigation of the following variables, using CBR tests for evaluation of stability:

1. gravel mixtures with low plasticity fines;

2. gravel mixtures with high plasticity fines;

3. crushed stone mixtures with low plasticity fines;

4. crushed stone mixtures with high plasticity fines.

In addition, triaxial compression tests were zun on the following:

1. crushed stone mixtures with non-plastic fines;

2. crushed stone mixtures with low plasticity fines;

3. gravel mixtures with low plasticity fines.

Permeablity testg were made on crushed stone and gravel mixtures having low plasticity flnes. 
REVIEW OF LITERATURE

\section{General Properties of Soll-Aggregate Mixtures}

Non-stabilized base courses are used under flexible pavements to increase the load-carrying capacity of the pavement by distributing the load through a finite thickness of pavement. This is the basic requirement for the base course, although it may provide drainage and give added protection against frost action. The strength properties of soll aggregate mixtures, when used in base courses, are influenced by their grain-size distribution, particle shape, plasticity, and permeability characteristics.

Under Iigid pavements, base courses are used to prevent pumping, provide protection against flost action, prevent volume change of the subgrade, expedite construction, and provlde drainage.

\section{- Effect of Fines}

The stability of a soil-aggregate mix depends on particle-size distribution, porticle shape, relative density, internal friction, and cohesion. Of these factors, the size distribution of the aggregate, particularly the proportion of fines to the coarse fraction is considered to be the most important factor. Figure 1 defines three idealized physical states of soil-aggregate mixes (19). Fines are defined as the proportion of the soll-aggregate mix passing the No. 200 sieve. 


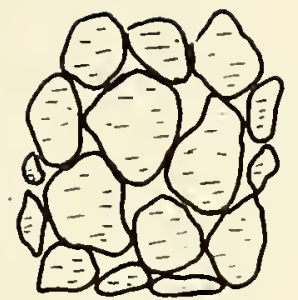

(a)

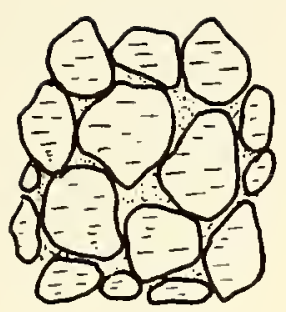

(b)

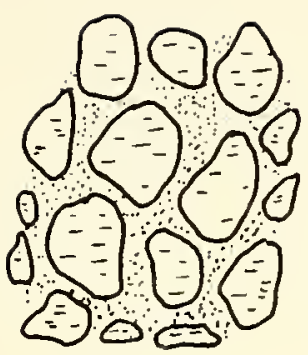

(c) (a) Aggregote with no fines

Grain-to-grain contact

Variable density

Pervious

Nonfrost susceptible

High stability if confined,

low if unconfined

Not affected by adverse

water condition

Difficult to compact (b) Aggregale with sufficient

fines for maximum density

Gran-tograin contact with

increased resistance agoinst

deformation

Increosed density

Low permeability

Frost susceptible

Relatively high stability

in confined or unconfined

conditions

Not greally affected by

odverse water condition

Moderately difficutt to

compac $\uparrow$ (c) Aggregate with great

omount of fines

Grain-to-grain contact

destroyed, cogregote "floot-

Ing" in soil

Decreased density

Low permeability

Frost susceptible

Low stobility

Greatly affected by adverse woter condition Not difficult to compact

FIG.I. PHYSICAL STATES OF SOIL-AGGREGATE MIXTURES (FROM YODER, PRINCIPLES OF PAVEMENT DESIGN, 1959) 
Yoder and Woods (21) studied the veriation of density and CBR with quantity of fines. The results of density and CBR tests made on soil-aggregate mixtures containing varlous percentages of fine material indicated that maximum densitfes for both well-graded crushed stone and gravel mixes resulted when the mixes contained between 8-10 percent fines. In contrast, maximum stability, as measured by the CBR test, regulted when gravel mixes contained $6-8$ percent fines and crushed stone mixes contained $5-7$ percent fines.

The results of work reported by Yoder and Woods indicated that:

1. For a given aggregate there is an optimum soll content at which maximum densities are attolned. The soll content for maximum strength is less than the optimum as determined by density tests.

2. Optimum soll content decreases as compactive effort increases.

3. From the standpoint of density and strength, a small amount of soll is a desirable addition to base-course aggregates, but larger quantities are detrimental.

Gray (11) Investigated the effect of quantity and plasticity of fines on gravels and crushed stone materials utilizing the triaxial tests. His results indicated that an excessive amount of fines not only lowers the load-carrying capacity of a base material, but may also make it frost susceptible. It is also possible that the optimum quantity of flnes for maximum strength may not be the same as the optimum quantity of fines for good frost resistance.

* Soll as used herein refers to material passing a No. 200 mesh sieve. 
A report by $A \& H$ Engineering and Testing Corporation (2) Indicated that the maximum triaxial compressive strength (applied lateral pressure $=5 \mathrm{psi}$ ) for crushed stone mixes occurred when nine percent fines were present. In case of gravel mixtures, 11 percent fines resulted in maxinum triaxial strength. A study of the variation of bearing ratios at 0.2 inch penetration with percent fines indicated that the maximum bearing ratios occurred when 9 and 11 percent fines were present in crushed stone and gravel mixes respectively.

To summarize, the quantity of fines in a soil-aggregate mix has a major influence on maximum density, strength, frost-resistance, and drainage.

\section{Effect of Crushed Materis 1}

The strength characteristics of aggregate bases and subbases are derived principally from inter-particle friction, and the amount of friction which is mobllized is a function of unit weight, the gradation of the particles, particle shape, and the surface texture of the particles. The permeability properties are also influenced by particle shape and surface texture.

The shape of particles and the surface texture has been defined as the "shape factor" by Townsend and Madill (18). The "shape factor" serves as a measure of angularity. Studies conducted by Townsend and Mad111 indicated that as the angularity of the coarse fraction of a soll-aggregate mix increases there is:

1. a slight decrease in the unit weight for the same compactive effort 
2. a substantial increase in the stabllity and strength of the material;

3. a decrease in the permeability of the material, if the void ratio is kept constant.

Yoder and Lowrie (20) determined that crushed stone is betrer than round-grained gravel with respect to pavement thickness. The difference between the two materials varled directly with gradation from coarse to Elne.

Yoder (19) found that relatively higher atrength values (as indicated by CBR tests) are obtained for crushed stone than for gravel mixes, for the same compactive effort and proportion of fines in the soil-aggregate mix. However, lower values of density may be obtained for crushed atone as compared to gravel.

\section{Effect of Plastictey}

Soll-aggregate mixtures exhibit greatest strength when nonplastic fines are used. There appears to be a definfte relationship between liquid limit, plasticity index, and the strength characteristics as measured by the CBR test. This relationship indicates that high plasticity is one of the most detrimental characteristics. There is a deflnite reduction in strength of the granular materials as plasticity index of the soll binder increases. A study made by the A \& Engineering and Testing Corporation (2) on the influence of plasticity on bearing ratio and criaxial compressive strength indicated that a substantial decrease in bearing ratio and triaxial strength occurs, In case of boch gravel and crushed stone mixes, wth increase in percentage of fines. This is due to the fact that an increase in 
the quantity of plastic fines in a given soll-aggregate mix would result in an increase in the plasticity of the mix.

The results of a series of tests by Deklotz performed on granular mixtures with three types of binders established that the effect of soll-binder plasticity was most pronounced for high soll contents (10).

To conclude, the plasticity index of the fine fraction has significant influence on the strength of granular materials. As the plasticity of the minus No. 40 material increases, the strength of the granular material is reduced. Although many specifications control the upper limit of PI at five or six percent, it should be recognized that the quantity of fines present in the soil-aggregate mixtures also influences the effect of plasticity.

As rule, the lowest possible plasticity index should be strived for in order to achieve the best performance, if the percentage of soil present in the soil-aggregate mixtures is above the value as obtained by:

$$
p=100 \sqrt{\frac{d}{D}}
$$

where

$$
\begin{aligned}
& d=\text { the size of opening of No. } 40 \text { sieve, } \\
& D=\text { the maximum size of the aggregate, } \\
& p=\text { percent of weight finer than No. } 40 \text { sieve. }
\end{aligned}
$$

\section{Permeability}

The permeability characteristics of soil-aggregate mixtures are dependent upon:

1. grain-size distribution;

2. type of coarse aggregate; 
3. type of binder;

4. density.

The perweability characteristics are related by:

$$
v=k i
$$

where

$$
\begin{aligned}
& v=\text { discharge velocity, } \\
& i=\text { hydraulic gradient (loss in head/unit length), } \\
& k=\text { coefficient of permeability. }
\end{aligned}
$$

The coefficient " $k$ " has the units of velocity and depends on the properties of the permeable mas8. It is also a function of density and viscosity of water. It is important to recognize that granular materials become less porous when soll binder is added. Crushed materials, in genersl, have higher rates of permeability, for a given gradation, than most common gravels $(4,18)$.

\section{Intrusion}

Soil-aggregate mixes used in base coulses must be designed with a-view to avoid intrusion of subgrade material into the base or removal of the fines from the mix by pumping under the action of repeated loads.

Yoder and Chamberlain (9) observed that an optimum range of grading exists within which a soll aggregate mix, used in a base course, will not experience significant subgrade intrusion into the base course. This range exists approximately between the grain-size distributions given by $p=100\left(\frac{d}{D}\right)^{n}$, where $n$ varies from 0.7 to 1.2 . 


\section{Effect of Skip-Grading}

Litrle or no work has been done on the effect of skip-grading of granular materials on the behavior of soil-aggregate mixtures. However, the effects on properties of bituminous concrete have been evaluated by several individuals.

Instances have been reported by varlous agencles where aggregate compatible with their own specifications resulted in bituminous mixtures that were difficult to compact and lemalned tender for some time after rolling. Others have reported instances of splotchy pavements resulting as a consequence of using such aggiegates. On plotting the percent pasaing a particular sieve vs. size of opening of the sleve raised to 0.45 power, the grading curves of these problem mixes Indicated a well-defined hump at the No. 30 and No. 50 sieve sizes. It was noted that when the hump in the gradation curve at the No. 30 and No. 50 sieve sizes was absent, the aggregates produced satiafactory bituminous mixtures (5).

According to the work done by the Bureau of Public Roads (5), nearly all gradation curves of problem mixtures have been characterlzed by $a$ hump above the max. density 1 ine at or near the No. 30 sieve; such mixtures had an excess of fine sard in relation to total ssnd. This excess not only results in lower compscted densities, but tends to float the larger particles and destroys stability that

\footnotetext{
Maximum density line is defined as the gradation curve obtained by using $n=0.45$ in the relationship, $p=100\left(\frac{d}{D}\right)^{0.45}$

where $p$ = percentage passing a partirular steve,

$D$ = maximum size of aggregate,

d a size of opening of the sieve.
} 
might otherwise result from coarse aggregate interlock. Also, fine sand is inherently less stable than coarse sand.

The report by the Bureau of Public Roads concluded that:

1. For gradations of the same type of aggregate which plot as identical curves except for the portion between No. 8 and No. 200 sieves, those that show apprectable humps above the maximum density line at about No. 30 sieve will have higher mineral voids and lower stabilities than those ploteing with lesser humps. Gradation humps in the finer aggregate sizes have a detrimental effect.

2. For skip-gradations, low mineral volds are associated with curves that stay appreclably below the maximum density line in the coarse aggregate zone.

\section{Specifications for Soil-Aggregate Mixtures}

Most specifications for base-course materials require that the plasticity index of the minus No. 40 sieve fraction of the mlx be no greater than six percent and the liquid limit should not exceed 25 percent. The first suggestions for a base-course specification, based on consistency 1 imits, date back to 1936 when Hogentogler and Willis (12) First formulated upper limits for the plasticity index and liquid limit.

Carpenter and W11is $(7,8)$ arrived at the same conclusion after conducting circular track tests on sand-clay, and gravel-sand-clay materials. 
The above mentioned results were then adopted by AASHO and these specified limits of plagticity Index and liquid limit together with limitg on grain-size distribution became the basis of specifications for coarse aggregates. Such opecificatlons are widely used by most highway departments. These specifications further require that the material be well-graded and place special emphasis on the amount of Eines permitted in the soil-aggregate mix.

The limiting plasticity values stipulated in most specifications do not appear to be supported by published verification, and possibly have evolved from purely empirical standpoint, dependent on performance in frost susceptible areas, as the criterion for evaluation.

Consequently, these limits are in certain cases restrictive. For example, when the amount of lines contained in the base-course Is low, it may be possible to permit some leeway in plasticity requirements without causing great harm to the mix. This would particularly hold for areas not subject to frost action.

Routine specification tests suffer from a number of limitations. It is difficult to obtain consistent and reproducible results from plasticity tests. Also, the interpretations possible from the same grading and plasticity data may vary considerably. Hence, the use of index properties as selection cirteria for soll-aggregate mixtures is at best debatable. This necessitates a critical approach to the design of specifications for pavement base materials and the investigation of a more rational method for selecting base-course materials.

Besides economic considerations, the stability of a pavement should be the guiding factor in establishing specifications to ensure 
stable and workable pavement materials. This indicates the need for a direct method of material selection by means of a strength test lather than by use of empirical soil parametels. In the present specifications, dependent primarily on consistency limits, the stability of the material is implied Iather than actually measured. Commonly, the CBR test is normally referred to for the valuation of atrength properties of base materials. In practice, this teat is rarely used for the selection of base course materials.

The Texas specifications (15) for flexible base materials offer another method for selection of adequate flexible base materials. Triaxial compressive strength together with consistency limits and grain-size distribution requirements form the criteria for evaluating base materlals. Table 1 shows the Texas requirements for flexible base materials.

According to the Texas method, Grade 1 material would be used in cases where special tough hard paiticles, which test as Triaxial Class 1, are to be used. Use would be limited to local areas. Grade 2 would be more widely used than Grade 1 because requirements are less strict and this material is still capable of supporting traffic when covered with a relatively thin bituminous surface. Triaxial strength requirements are necessary in order to assure this. Generally, most final base courses should be equal to or better than Grade 2. Grade 3 generally represents satisfactory subbase materials. Grade 4 material is intended for use as stabilized bases; however, these are generally used for light traffic roads where a surfacing may need to be placed on such material. There are isolated cases 
TABLE I. PHYSICAL REQUIREMENTS FOR FLEXIBLE BASE MATERIAL* (FROM TEXAS HIGHWAY DEPARTMENT).

\begin{tabular}{|c|c|c|c|c|c|c|c|}
\hline \multirow[b]{2}{*}{ TYPES } & \multicolumn{7}{|c|}{ GRADES } \\
\hline & $\begin{array}{l}\text { GRADE I: TRIAXIAL } \\
\text { MIN. COMPRESSIVE S } \\
\text { PSI: } 45 \text { AT O LB LA } \\
\text { PRESSURE AND I75 } \\
\text { LATERAL PRESSUR }\end{array}$ & $\begin{array}{l}\text { CLASS I } \\
\text { TRENGTH } \\
\text { TERAL } \\
\text { AT IS LB } \\
\text { E }\end{array}$ & $\begin{array}{l}\text { GRADE 2: (TRIA) } \\
\text { TO 2.3) MIN CO } \\
\text { STRENGTH,PSI } \\
\text { LATERAL PRES } \\
\text { AT IS LB LATER }\end{array}$ & $\begin{array}{l}\text { CLASS I } \\
\text { ESSIVE } \\
\text { AT O LB } \\
\text { RE AND I75 } \\
\text { RESSURE }\end{array}$ & $\begin{array}{l}\text { GRAOE 3: (UNSPE } \\
\text { TRIAXIAL CLAS } \\
\text { PROBABLY FRO } \\
3.7 \text { ) }\end{array}$ & $\begin{array}{l}\text { FIED } \\
\text { RANGE } \\
2.3 \text { TO }\end{array}$ & $\begin{array}{l}\text { GRADE } \\
\text { 4:SHOW } \\
\text { SPEC. } \\
\text { UMITS } \\
\text { ON } \\
\text { PLANS }\end{array}$ \\
\hline $\begin{array}{l}\text { TYPE A } \\
\text { CRUSHED } \\
\text { OR } \\
\text { BROKEN } \\
\text { AGGREGATE }\end{array}$ & $\begin{array}{l}\text { RETAINED ON } \\
\text { SQ. SIEVE } \\
\text { | } 3 / 4^{\prime \prime} \\
7 / 8 \\
3 / 8 \\
\text { NO. } 4 \\
\text { NO. } 40 \\
\text { MAX. LL } \\
\text { MAX.PI } \\
\text { MAX WET BALL MIL } \\
\text { MAX. LA WEAR + } 4\end{array}$ & $\begin{array}{r}\% \\
0 \\
8-30 \\
30-50 \\
45-65 \\
70-80 \\
35 \\
12 \\
40 \\
40\end{array}$ & $\begin{array}{l}\text { RETAINED ON ' } \\
\text { SQ. SIEVE } \\
\text { I } 3 / 4^{\prime \prime} \\
\text { NO. } 4 \\
\text { NO. } 40 \\
\text { MAX. LL } \\
\text { MAX. PI } \\
\text { MAX WET BALL }\end{array}$ & $\begin{array}{r}\% \\
0-10 \\
45-75 \\
60-85 \\
40 \\
12 \\
50\end{array}$ & $\begin{array}{l}\text { RETAINED ON } \\
\text { SO. SIEVE } \\
\text { I } 3 / 4^{\prime \prime} \\
\text { NO. } 40 \\
\text { MAX.LL } \\
\text { MAX. PI } \\
\text { WET BALL MILL }\end{array}$ & $\begin{array}{r}\% \\
0-10 \\
60-85 \\
45 \\
15 \\
55\end{array}$ & 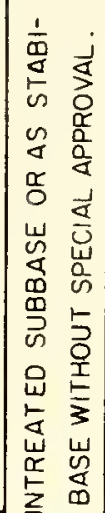 \\
\hline $\begin{array}{l}\text { TYPE B } \\
\text { GRAVEL } \\
\text { AGGREGATE }\end{array}$ & & & $\begin{array}{l}\text { RETAINED ON } \\
\text { SO. SIEVE } \\
\text { I } 3 / 4^{\prime \prime} \\
\text { NO. } 4 \\
\text { NO. } 40 \\
\text { MAXLL } \\
\text { MAX.PI }\end{array}$ & $\begin{array}{r}\% \\
0-10 \\
30-75 \\
70-85 \\
35 \\
12\end{array}$ & $\begin{array}{l}\text { RETAINED ON } \\
\text { SO. SIEVE } \\
\text { I } 3 / 4^{\prime \prime} \\
\text { NO. } 4 \\
\text { NO. } 40 \\
\text { MAX LL } \\
\text { MAX.PI }\end{array}$ & $\begin{array}{r}\% \\
0-5 \\
30-75 \\
65-85 \\
35 \\
12\end{array}$ & 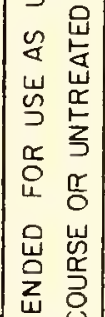 \\
\hline $\begin{array}{l}\text { TYPE C } \\
\text { IRON ORE } \\
\text { TOP SOIL }\end{array}$ & & & $\begin{array}{l}\text { RETAINED ON } \\
\text { SO SIEVE } \\
21 / 2^{\prime \prime} \\
\text { NO } 40 \\
\text { MAX LL } \\
\text { MAX.PI }\end{array}$ & $\begin{array}{r}\% \\
0 \\
50-85 \\
35 \\
12\end{array}$ & $\begin{array}{l}\text { RETAINED ON } \\
\text { SO SIEVE } \\
\text { NO } 40 \\
\text { MAX.LL } \\
\text { MAX.PI }\end{array}$ & $\begin{array}{r}\% \\
45-85 \\
35 \\
12\end{array}$ & 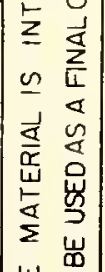 \\
\hline $\begin{array}{l}\text { TYPE D } \\
\text { SAND - } \\
\text { SHELL }\end{array}$ & & & $\begin{array}{l}\text { RETAINED ON } \\
\text { SO SIEVE } \\
\text { I } 3 / 4^{\prime \prime} \\
\text { NO } 4 \\
\text { NO. } 40 \\
\text { MAX.LL } \\
\text { MAX PI }\end{array}$ & $\begin{array}{r}\% \\
0-10 \\
45-65 \\
50-70 \\
35 \\
12\end{array}$ & $\begin{array}{l}\text { RETAINED ON } \\
\text { SQ SIEVE } \\
\text { I } 3 / 4^{\prime \prime} \\
\text { NO. } 40 \\
\text { MAX LL } \\
\text { MAX.PI }\end{array}$ & $\begin{array}{r}\% \\
0-10 \\
45-65 \\
35 \\
12\end{array}$ & 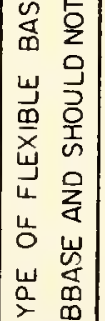 \\
\hline $\begin{array}{l}\text { TYPE E } \\
\text { SHELLWTHH } \\
\text { SAND AND } \\
\text { CALICHE } \\
\text { ADMIXTURE }\end{array}$ & & & $\begin{array}{l}\text { RETAINED ON } \\
\text { SQ. SIEVE } \\
13 / 4 " \\
\text { NO. } 40 \\
\text { MAX LL } \\
\text { MAX.PI }\end{array}$ & $\begin{array}{r}\% \\
0 \\
45-65 \\
35 \\
10\end{array}$ & $\begin{array}{l}\text { RETAINED ON } \\
\text { SO. SIEVE } \\
13 / 4 " \\
\text { NO. } 40 \\
\text { MAX.LL } \\
\text { MAX.PI }\end{array}$ & $\begin{array}{r}\% \\
0 \\
45-65 \\
35 \\
12\end{array}$ & 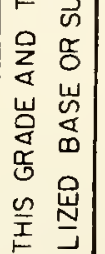 \\
\hline
\end{tabular}

* limit tests made after material is prepared by wet method 
where very rocky materials with high PI may give satisfactory services and adequate triaxial zesults. Grade 4 would take care of these unusual, but explainable circumstances (15).

McDowell (16) compared the AASHO and Texas specifications for flexible base materials. As a result of this study, McDowell concluded that the performance of roads in Texas showed no relationship with the soil constants (liquid limit and plasticity index) and he further concluded that the results of his study did not substantiate the specifications set up by AASHO. Many of the materials tested by McDowell contalned low percentages of fines. McDowell further suggested that the AASHO should reconsider the specifications for soil-aggregate mixtures and recomended that liquid limit values as high as 35 percent and plasticity index values as high as 12 percent may be permitted. However, suggestions by McDowell must be modified on the basls of the fact that the Texas Highway Department uses the "wet" method for preparing samples for the consistency limits tests. In general, "wet" preparation method results in higher indices than would be obtalned using the dry preparation method.

The method of evaluating base course material by means of the Texas method offers a rational means of selecting base materials and exhibits obvious virtues as compared with the purely empirical methods that are generally in vogue at present. 


\section{EXPER IMENTAL PROGRAM}

This study was confined to base course materials that essentially conform with Indiana specification size No. 53 aggregate. The amount of material between the No. 30 and No. 200 mesh sieves was varied to study the effect of this variation on stability characteristics of soil aggregate mixtures.

The specifications for sizé No. 53 aggregate are given in Table 2 .

TABLE 2. SPECIFICATIONS FOR INDIANA SIZE NO. 53 AGGREGATE

\begin{tabular}{|c|c|c|c|c|c|c|c|c|}
\hline \multirow{2}{*}{\begin{tabular}{|} 
Indiana Size \\
No. 53
\end{tabular}} & \multicolumn{6}{|c|}{ Total Percent Passing Sicve Having Square Opening } \\
\cline { 2 - 8 } & $1 \frac{2}{2} "$ & $1^{\prime \prime}$ & $3 / 4^{\prime \prime}$ & $1 / 2^{\prime \prime}$ & \#4 & \#8 & \#30 & \#200 \\
\cline { 2 - 8 } & 100 & $80-100$ & $70-90$ & $55-80$ & $35-60$ & $25-50$ & $15-30$ & $5-10$ \\
\hline
\end{tabular}

The specifications futther require that the gradation of material above the No. 8 sieve shall be uniform within the limits shown and shall not vary from the low limit on one sieve size to the high limit on the adjacent sieve size. The fraction passing the No. 200 sieve shall not exceed $2 / 3$ the fraction passing the No. 40 sieve. These specifications further stipulate that the liquid limit of the fraction passing the No. 40 sieve shall not exceed 25 percent and the plasticity index shall not exceed 5 percent. 
In Figure 2, the bold curves show the grading limits for the Size No. 53 aggregate. The curve between these limits indicates the grain-size distribution for a material conforming to the maximum density gradation equation,

$$
p=100\left(\frac{d}{D}\right)^{n}
$$

where

$$
\begin{aligned}
& \mathrm{p}=\text { percent by weight finer than a given sieve, } \\
& \mathrm{d}=\text { size of given sieve, } \\
& \mathrm{D}=\text { maximum size of aggregate, } \\
& \mathrm{n}=0.5 .
\end{aligned}
$$

For this study D was held constant at $1^{\prime \prime}$. Hence,

$$
p=100 \sqrt{d}
$$

where

$$
\mathrm{d}=\text { size of sieve opening in inches. }
$$

After comparing the Indiana specifications for No. 53 aggregate and the grain-size distribution for maximum density as shown in Figure 2, the grain-size distributions for the materials to be tested were selected. These are shown in Figures 3 and 4 . In a11 cases, the grain-size distributions through the No. 8 sieve remained the same.

In order to study the effect of skip-grading between the No. 30 and No. 200 mesh sieves, two specific cases were studied. In the first case, the quantity passing the No. 200 mesh sieve was held constant at five percent and the total percent passing the No. 30 sieve was varied from 25 percent to five percent at increments of 


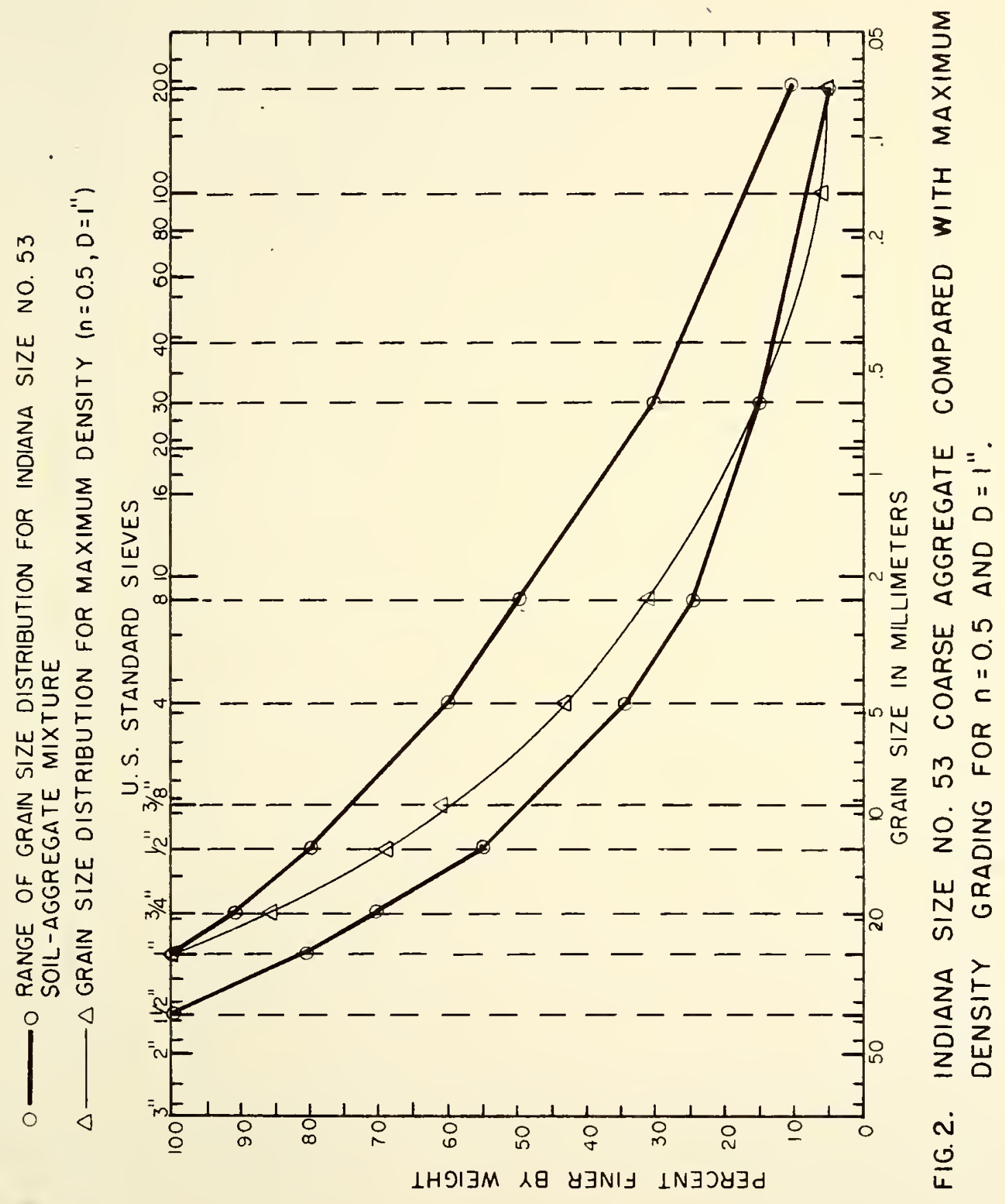




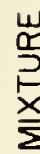

w

它

淢 웡

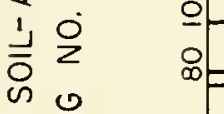

ก $\frac{2}{\mathrm{n}}$

운

录

un

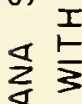

号

땅

은

品

品岩

品

嵌 $\frac{z}{5}$

䒜

采

岁 $\frac{w}{n}$

岁 $\frac{z}{\text { 䒾 }}$

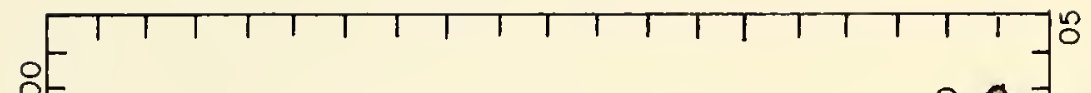

距

$=$

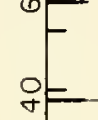

$-$

N=

$n \stackrel{n=}{N E}$

w

$\frac{w}{\omega}$

-

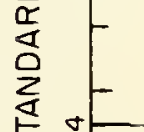

is

i $=$

年-
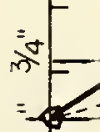

$=$
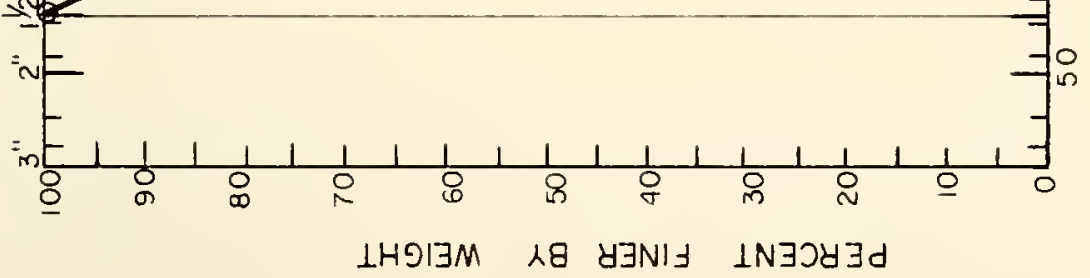

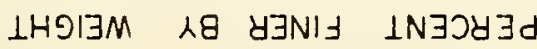

$\stackrel{\Sigma}{\Sigma}$

$\sum_{\Sigma}^{W}$

的

岂

O 4

$\left.\right|_{0} \begin{aligned} & 1 \\ & 1 \\ & 1 \\ & 1\end{aligned}$

$\frac{m}{4}$ 


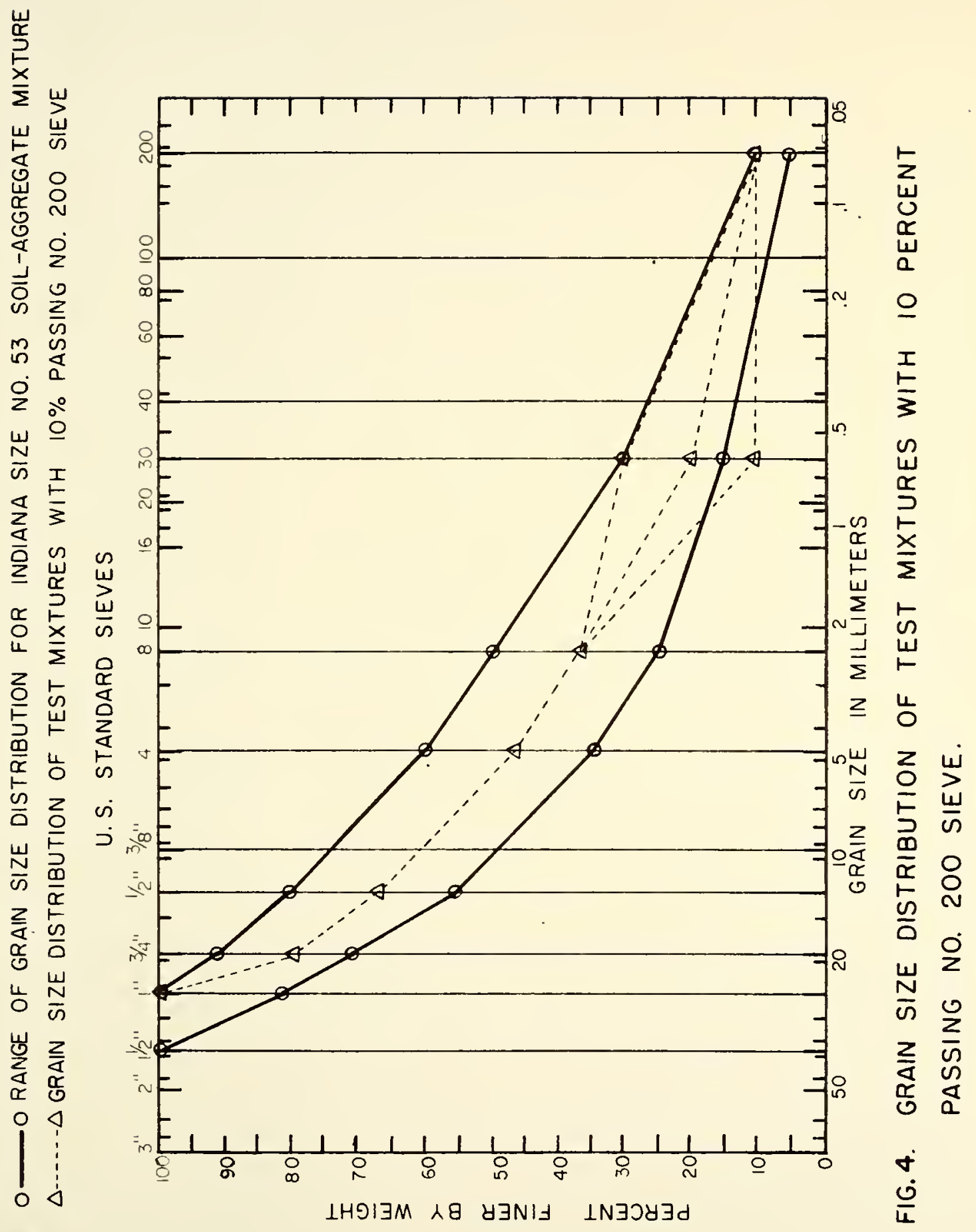


ten percent (Figure 3). In the second case, the quantity passing the No. 200 sieve was held constant at ten percent while the total percent passing the No. 30 sieve was varled from 30 percent to ten percent at increments of ten percent (Figure 4). It may be of Interest to note that in both cases the amount of material retained between the No. 30 and No. 200 sieves was varled from 20 percent to zero percent at increments of ten percent.

These distributions resulted in six distinct soil-aggregate mixtures. The gradations for these materials are shown in Table 3 .

\section{Materials}

The materials used in this study consisted of gravel and crushed stone agglegates. These materials were obtained from local stockpiles. In order to encompass a relatively wide range of plasticity values, four different types of soil binders were used.

A soll binder in this study is defined as the material passing the No. 200 sieve. Henceforth, 811 such materials will be termed as fines. The plasticity characteristics of the different types of fines are summarized in Table 4. These fines will be referred to using the descriptive terms shown in the last column of Table 4.

To manuiacture the test mixtures, No. 1 fines (CL, low PI) were combined with gravel, whereas No. 2 fines (CL-ML, low PI) were combined wth crushed stone. The No. 3 fines ( $\mathrm{CH}$, high PI) were uaed with both gravel and crushed stone in high PI mixtures. The No. 4 fines (ML, NP) were combined only with cruahed stone to prepare test mixtures for triaxial compression tests. 
TABLE 3. GRAIN SIZE DISTRIBUTION OF TEST MIXTURES

\begin{tabular}{|c|c|c|c|c|c|c|}
\hline $\begin{array}{l}\text { PERCENT PASSING } \\
\text { NO. } 200 \text { SIEVE }\end{array}$ & \multicolumn{3}{|c|}{5} & \multicolumn{3}{|c|}{10} \\
\hline $\begin{array}{l}\text { PERCENT RETAINED } \\
\text { BETWEEN NO. } 30 \text { AND } \\
\text { NO. } 200 \text { SIEVES }\end{array}$ & 0 & 10 & 20 & 0 & 10 & 20 \\
\hline TEST MIXTURE NO. & 1 & 2 & 3 & 4 & 5 & 6 \\
\hline GRAIN SIZE & $\begin{array}{l}\text { PERCENT } \\
\text { FINER }\end{array}$ & $\begin{array}{l}\text { PERCENT } \\
\text { FINER }\end{array}$ & $\begin{array}{l}\text { PERCENT } \\
\text { FINER }\end{array}$ & $\begin{array}{l}\text { PERCENT } \\
\text { FINER }\end{array}$ & $\begin{array}{l}\text { PERCENT } \\
\text { FINER }\end{array}$ & $\begin{array}{l}\text { PERCENT } \\
\text { FINER }\end{array}$ \\
\hline $1^{\prime \prime}$ & 100 & 100 & 100 & 100 & 100 & 100 \\
\hline $3 / 4^{11}$ & 80 & 80 & 80 & 80 & 80 & 80 \\
\hline $1 / 2$ & 67.5 & 67.5 & 67.5 & 67.5 & 67.5 & 67.5 \\
\hline $3 / 8 "$ & 61.5 & 615 & 61.5 & 61.5 & 61.5 & 61.5 \\
\hline NO. 4 & 47.5 & 47.5 & 47.5 & 47.5 & 47.5 & 47.5 \\
\hline NO. 8 & 37.5 & 37.5 & 37.5 & 37.5 & 37.5 & 37.5 \\
\hline NO. 30 & 5 & 15 & 25 & 10 & 20 & 30 \\
\hline NO. 200 & 5 & 5 & 5 & 10 & 10 & 10 \\
\hline
\end{tabular}




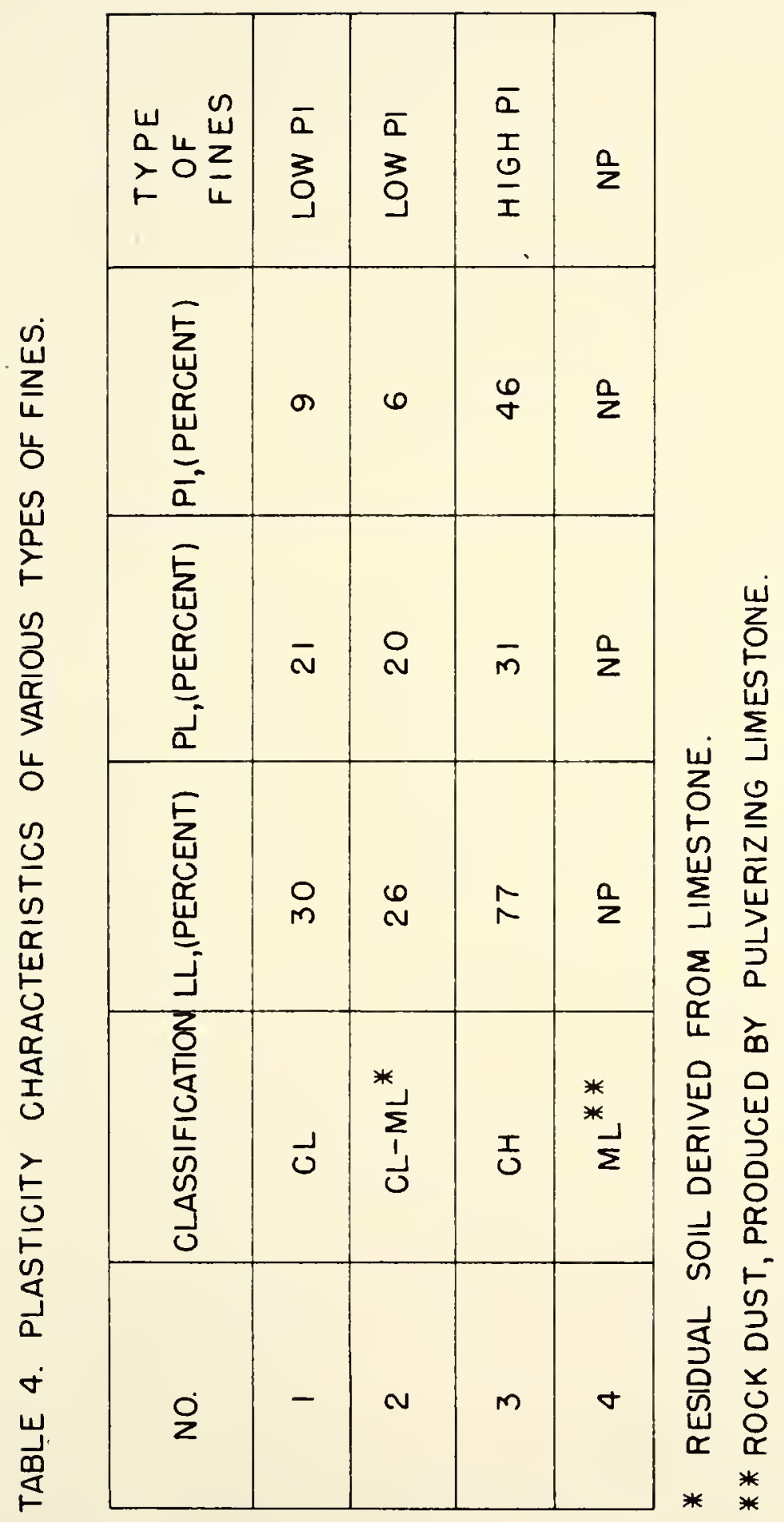




\section{Evaluated Variables}

To evaluate stability and strength characteristics, California Bearing Ratio (CBR) teat and Texas triaxial test were used. Permeability tests were run on selected samples to evaluate drainage characteristics. Before these, a series of routine soll tests were run. These consisted of limits testa and compaction tests.

CBR tests were run on a relatively large variety of sollaggregate mixes. Both gravel and crushed stone were used. Soil binders were conflned to low PI and high PI fines. For any combination of aggregates and fines, six distinct mixes were used, as described earlier. As both gravel and crushed stone were used, each with two different types of fines, a total of 24 different soilaggregate mixes resulted. Prior to running the CBR tests, limits tests and compaction tests were made on each of these soll-sggregate mixtures to evaluate plasticlty index, maximum dengity, and optimum molsture content.

Texas triaxial tests were confined to the following materials:

1. gravel with low PI fines;

2. crushed stone with low PI fines;

3. crushed stone with NP fines.

This resulted in 18 distinct test mixtures. Prior to running the triaxial compression tests, compaction and limits tests were run on each test mixture.

Permeability tests were run only on crushed stone and gravel mixtures with low PI fines. This resulted in 12 test mixtures. 


\section{Design of Experiments}

The design of an experiment involves planning an experiment so that information will be collected which is relevant to the problem under investigation. Thus, it is the complete sequence of steps taken ahead of time to insure that the appropilate data will be obtained in a way which permits an objective analysis leading to valid inference. The purpose of any experimental design is to provide a maximum amount of information relevant to the problem under investigation.

The three bastc principles of experimental design are replication, randomization, and local control. Replication means the repetition of the basic experimental unit. This provides an estimate of experimental erlor which acts as a unit of measuling and assessing the significance of observed differences. Randomization refers to the random assignment of treatments to the experimental units so that the treatments will not be favored or handicapped systematically by extraneous sources of variation. Local control refers to controls, like balancing, blocking, or grouping, applied to the experimental units. The function of local control is to make any test of signif-. icance more sensitive or to make the test procedure more powerful.

Definitions (17):

1. Experimental Unit:

is that unit to which a single treatment (which may be a combination of many factors) is applied in one replication of the basic experiment. 
2. Experlmental Error:

describes the failure of two identically treated experimental units to yleld identical results. This incorporates errors of experfment, errors of observation, errors of measurement, variation of experimental materlal, and extraneous factors which could affect the outcome of experiments, but which are not singled out.

3. Treatment :

this implies a particular set of experimental conditions which will be imposed on an experimental unit within the confines of the chosen design.

4. Factor:

is an independent variable.

Example: in CBR testing, a treatment might refer to a) molding molsture content; b) soaking or absence of it; c) surcharge weights; d) type of compaction; or d) a combination of the above. The last treatment would be called a treatment combination.

A brief description of the experimental designa used in this study is given below.

CBR Tests. A $2 \times 2 \times 2 \times 3 \times 2$ factorlal design was used for the CBR teats. The five independent varlables or factors involved in this experiment were:

1. material type;

2. plasticity of fines;

3. percent material passing the No. 200 sleve (percent flnes); 
4. percent material retained between the No. 30 and No. 200 sieves;

5. percent compactive effort used in molding the CBR specimens. The dependent or the measured variable was the California Bearing Ratio (CBR). The experiment was completely replicated and all experimental units were randomized. This means that the CBR tests were performed in a random order to reduce systematic blas introduced by experimental error and other unquantifled extraneous effects. Two CBR tests were run per experimental unit.

Texas Triaxial Tests. Two factorial designs were used for the Texas triaxtal compression tests. Both designs were $2 \times 2 \times 3$ factorials. In the first design, the three independent variables or factors consisted of the following:

1. material type;

2. percent passing the No. 200 sieve (percent fines);

3. percent retained between the No. 30 and No. 200 sieves. In the second deslgn, the three Independent variables or factors consisted of:

1. plasticity of fines;

2. percent passing the No. 200 sieve (percent fines);

3. percent retained between the No. 30 and No. 200 sieves. In these designs, the measured varlables were the triaxlal compressive strength at $15 \mathrm{ps} 1$ lateral pressure and the angle of internal friction. 
Replication was not used in the triaxial tests, i.e., only one set of observations was taken pel experimental unit. However, the triaxial tests were performed in a random order.

Permeability Tests. A study of published data did not justify a factorial design as the results of these tests are easy to analyze and the significance of various factors involved in the experimentation can be evaluated whthout taking recourse to statistical analysis. 


\section{TEST PROCEDURES}

The experimental program involved the use of the following tests:

1. Atterbeig limits tests;

2. Compaction tests;

3. CBR test;

4. Texas triaxial test;

5. Permeability test.

\section{Preparation of Materials}

In order to prepare the test mixtures, the gravel and crushed stone were separated into fractions and recombined as desiled. Similarly, the fines were prepared separately and added to the. aggregates in desired quantity. The bulk material was first dry sieved into the following eight fractions: $1 "-3 / 4^{\prime \prime} ; 3 / 4^{\prime \prime}-1 / 2^{\prime \prime}$; $1 / 2^{\prime \prime}-3 / 8^{\prime \prime} ; 3 / 8^{\prime \prime}-$ No. 4 ; No. 4 -No. 8 ; No. 8 -No. 30 ; No. $30-$ No. 200 ; and minus No. 200. Then the coarse fractions (retained No. 200 sleve) were wet sleved to remove all surface fines. These fractions were combined in accordance with the gradations outlined in Table 3 to give the six typical test mixtures for each combination of aggregates and fines. 


\section{Atterberg Limits Tests}

The liquid limit and plastic limit were determined in accordance with ASTM Designations D 423-61T and D 424-59 respectively (3). However, the method of preparing test samples was slightly modifled. For any soil-aggregate mix under investigation the ratio of percent retained between the No. 40 and No. 200 sieves to percent fines (passing No. 200 steve) was determined from the grain-size distribution curves shown in Figures 3 and 4 . Then the soil-aggregate fraction retalned between the No. 40 and No. 200 sieves was combined with the passing No. 200 fraction, in accordance with this Iatio, to prepare the test sample.

\section{Compaction Tests}

The compaction tests run prior to CBR testing were conducted in accordance with ASTM Designation D 698-64T, method-D (3). In all such tests, material retained on $3 / 4-i n$. sieve was replaced by an equal welght of material passing the $3 / 4-i n$. sleve and retained on No. 4 sieve.

In case of the preliminary compaction tests preceding the Texas triaxial tests, a modified method was used. The size of mold used for compaction was 6-in. diameter, and 8-in. in height. In order to obtain a compactive effort of $13.26 \mathrm{ft} .-1 \mathrm{~b}$. per cu. in., the soil was compacted in four layers with 50 blows applied to each layer. A 10-1b. hammer with a free fall of 18-in. was used. The procedure for determining the optimum moisture content and maximum density remained the same as outlined in ASTM Designation D 698-64T. The material retained on $3 / 4-$ in. sieve was not replaced. 


\section{Cali fornia Bearing Ratio Test}

Soaked CBR tests were performed in accordance with ASTM Designation D1883-61T (3). The test specimens were soaked and tested under a surcharge of $10 \mathrm{lb}$. Each soil-aggregate mix was molded using two different compactive efforts. In the first instance the compactive effort was 56 blows, applied to three equal layers with a $5 \frac{1}{2} \mathrm{lb}$. hammer as specified in ASTM Designation D1883-61T. In the second case the compactive effort was reduced by 50 percent and the specimens were molded by 28 blows of a $5 \frac{1}{2} 1 \mathrm{~b}$. hamer applied to each of the three equal layers.

In each case the test was replicated, i.e., for each soilaggregate mix, four CBR tests were conducted. For two tests 56-blow compaction was utilized whereas for the other two, the compactive effort was reduced to 28 blows per layer.

\section{Texas Triaxial Test}

In essence, the Texas triaxial tests conformed to AASHO designa- tion T 212-65 (I). However, slight modffications were effected in the standard method. The version of Texas triaxlal test used in this study could be termed as an abbreviated (unsoaked) test. Three test specimens of each soll-aggregate type were molded at optimum moisture content, as determined by the compaction test described earlier. These specimens were tested immediately after molding in accordance with the test method outlined in AASHO designation T212-65. The confining pressure was varied from 5 psi to 15 psi with an intermediate value of $10 \mathrm{psi}$. Test results were reported in terms of the 
Texas triaxial class, the trlaxial compressive strength obtained at a confining pressure of $15 \mathrm{pgi}$, and the angle of internal friction obtalned from the Mohr's envelope.

\section{Permeability Test}

A constant head permeameter was used for this test. The permeameter was locally constructed and in principle the design conforwed to the one outlined in the "Proposed Method of Test for Permeability of Granular Soils" under the jurisdiction of ASTM Committee D-18 (3). The testing procedure also conformed to the proposed method.

The permeameter cylinder had a 6-in. diameter and a 7 -in. height. The test samples were molded dynamically by a 10-1b. sliding hammer with an 18-in. drop. The sotl was placed in four layers and 44 blows were applied to each layer. This resulted in a compactive energy of 13.26 ft.-1b. per cu. In. It may be recalled here that the samples for the triaxial tests were molded using the same compactive energy. Hence, the test samples for both the permeability and Texas tilaxial tegts were molded using the same degree of compaction. This offered a common basis for comparing the permeability and triaxial strength characteristics of various soil-aggregate mixes.

The coefficient of permeability was computed using the formula,

$$
k=\frac{Q L}{A t h}
$$

where

$$
\begin{aligned}
& k=\text { coefficient of peimeabllity }(\mathrm{cm} / \mathrm{sec}), \\
& Q=\text { quantity of water discharged }\left(\mathrm{cm}^{3}\right), \\
& L=\text { height of sample }(\mathrm{cm}),
\end{aligned}
$$



$A=$ cross-sectional area of sample $\left(\mathrm{cm}^{2}\right)$,
$t$ = total time of discharge (sec),
$h=$ total head lost (cm). 


\section{RESULTS}

\section{Test Data}

Test data are presented in Appendix 1. Molsture content-density data for CBR tests are shown in Table A-1; CBR data are tabulated in Table A-2; Compaction test data for triaxial compressive tests are shown in Table A-3; and Table A-4 shows the Texas triaxial test results. The results of permeability tests are presented in Table A-5. The limits tests dats are shown in Tables A-2 and A-4.

\section{Statistical Analysis}

Statistical anslysis was used in onalyzing the CBR and Texas trlaxial test data. The statistical tool most often used in this study was analysis of variance. The permeability test data did not justify the use of statisticsl analysis as the test results could be analyzed in the light of simllar studies in the past.

\section{CBR Test Data}

The following analysis of varlance model was formulated for the CBR test results:

$$
\begin{aligned}
Y_{i j k l m n}= & U+A_{i}+B_{j}+C_{k}+D_{l}+F_{m}+A_{i j}+A C_{i k} \\
& +A D_{i l}+A F_{i m}+B C_{j k}+B D_{j l}+B F_{j m}+C_{k l} \\
& +C F_{k m}+D F_{1 m}+A B C_{i j k}+A B D_{i j l}+A B F_{i j m} \\
& +A C D_{i k l}+A C F_{i k m}+A D F_{i l m}+B_{j k l}+B C F_{j k m}
\end{aligned}
$$




$$
\begin{aligned}
& +\mathrm{BDF}_{j 1 \mathrm{~m}}+\mathrm{CDF}_{k 1 m}+\mathrm{ABCD}_{1 j k l}+\mathrm{ABCF}_{i j k m} \\
& +\mathrm{ABDF}_{i j l m}+\mathrm{ACDF}_{1 k 1 m}+\mathrm{BCDF}_{j k 1 m}+\mathrm{ABCDF}_{1 j k 1 m} \\
& +E_{n(1 j k l m)}
\end{aligned}
$$

where

$$
\begin{aligned}
\mathrm{Y}_{\text {Ijklmn }}= & \text { CBR value obtained from a given test, } \\
\mathrm{U}= & \text { true mesn value for the population, } \\
A_{1} & \text { true differential effect of aggregate type } \\
& \text { (gravel vs. crushed stone), } \\
= & \text { true differential effect of plasticity of } \\
B_{j} & \text { fines (low vs. high), } \\
= & \text { true differential effect of percent passing } \\
C_{k} & \text { No. } 200 \text { sieve (5\% vs. } 10 \%), \\
= & \text { true differential effect of percent retained } \\
& \text { between the No. } 30 \text { and No. } 200 \text { sieves, } \\
D_{1} & \text { true differential effect of compaction } \\
E_{n(i j k l m)=} & \text { true error effect of replicates. } \\
F_{m} & \text { (56 blows vs. } 28 \text { blows), } \\
&
\end{aligned}
$$

The other terms denote interactions between the main effects $A, B$, $C, D$, and $F$. The subscripts assume the values:

$$
\begin{aligned}
& \mathbf{i}=1,2 \\
& j=1,2 \\
& \mathbf{k}=1,2 \\
& 1=1,2,3 \\
& \mathbf{m}=1,2 \\
& \mathbf{n}=1,2 .
\end{aligned}
$$


In the ANOVA model, main effects A, B, C, D, and $E$ are fixed while the effect $\mathrm{E}$ is random.

The fixed-effect model for the CBR data was formulated on the basis of the following assumptions:

1. homogeneity of variance;

2. normality;

3. additivity;

4. independence of the errors.

As there were only two replicates for each treatment combination, Bartlett's test and q-test could not be used for testing the assumption of homogeneity of variance. In order to accomplish this end, the range test was used.

Table 5 shows the CBR data layout for analysis of variance. It will be seen from this table that there are 48 cells consisting of two replicates each. Table 6 gives the range and mean of the CBR values within each of the 48 cells. In this discussion, $\bar{x}$ represents the cell mean value while $R$ represents the range value. From Table 6 ,

$$
\begin{aligned}
& \sum_{i=1}^{48} R_{i}=659.2 \\
& \quad \bar{R}=\frac{\sum R}{48}=\frac{659.2}{48}=13.73
\end{aligned}
$$

The control limits (6) are given by,

$$
\begin{aligned}
& \operatorname{UCL}_{R}=D_{4} \bar{R} \\
& \mathrm{LCL}_{\mathrm{R}}=\mathrm{D}_{3} \overline{\mathrm{R}}
\end{aligned}
$$


TABLE 5. SUMMARY OF CBR TEST DATA.

\begin{tabular}{|c|c|c|c|c|c|c|c|}
\hline \multirow{3}{*}{$\begin{array}{l}\text { AGGREGATE } \\
\text { TYPE }\end{array}$} & \multirow{3}{*}{$\begin{array}{l}\text { PLASTICITY } \\
\text { OF FINES }\end{array}$} & \multirow{3}{*}{$\begin{array}{l}\text { PERCENT } \\
\text { PASSING } \\
\text { NO. } 200 \\
\text { SIEVE }\end{array}$} & \multirow{3}{*}{$\begin{array}{l}\text { PERCENT } \\
\text { RETAINED } \\
\text { BETWEEN } \\
\text { NO. } 30-N O \\
200 \text { SIEVES }\end{array}$} & \multicolumn{4}{|c|}{ COMPACTION } \\
\hline & & & & \multicolumn{2}{|c|}{56 BLOWS } & \multicolumn{2}{|c|}{28 BLOWS } \\
\hline & & & & 1 & 2 & 1 & 2 \\
\hline \multirow{12}{*}{$\begin{array}{l}\frac{1}{w} \\
\geq \\
\frac{\pi}{x} \\
0\end{array}$} & \multirow{6}{*}{ LOW } & \multirow{3}{*}{5} & 0 & 60.0 & 46.7 & 45.3 & 34.2 \\
\hline & & & 10 & 88.8 & 96.7 & 38.3 & 49.3 \\
\hline & & & 20 & 98.9 & 95.0 & 73.3 & 75.3 \\
\hline & & \multirow{3}{*}{10} & 0 & 184.9 & 182.6 & 76.7 & 77.8 \\
\hline & & & 10 & 130.0 & 153.0 & 102.7 & 99.3 \\
\hline & & & 20 & 61.4 & 53.3 & 49.3 & 70.7 \\
\hline & \multirow{6}{*}{$\mathrm{HIGH}$} & \multirow{3}{*}{5} & 0 & 97.0 & 52.0 & 46.7 & 31.3 \\
\hline & & & 10 & 77.3 & 80.0 & 57.3 & 45.0 \\
\hline & & & 20 & 113.3 & 85.3 & 44.0 & 83.3 \\
\hline & & \multirow{3}{*}{10} & 0 & 88.0 & 60.0 & 43.3 & 32.6 \\
\hline & & & 10 & 30.0 & 26.7 & 32.0 & 23.3 \\
\hline & & & 20 & 25.3 & 44.0 & 22.0 & 28.0 \\
\hline \multirow{12}{*}{$\begin{array}{l}\text { W } \\
\stackrel{0}{\circ} \\
\text { n }\end{array}$} & \multirow{6}{*}{ LOW } & \multirow{3}{*}{5} & 0 & 52.0 & 51.5 & 46.7 & 38.0 \\
\hline & & & 10 & 110.7 & 81.4 & 43.3 & 60.0 \\
\hline & & & 20 & 143.3 & 145.0 & 128.0 & 108.0 \\
\hline & & \multirow{3}{*}{10} & 0 & 101.4 & 100.0 & 46.7 & 64.7 \\
\hline & & & 10 & 128.0 & 144.7 & 98.7 & 70.0 \\
\hline & & & 20 & 123.3 & 163.3 & 125.3 & 96.7 \\
\hline & \multirow{6}{*}{$\mathrm{HIGH}$} & \multirow{3}{*}{5} & 0 & 80.0 & 51.6 & 37.3 & 24.7 \\
\hline & & & 10 & 93.9 & 86.7 & 80.0 & 73.7 \\
\hline & & & 20 & 118.7 & 120.0 & 53.3 & 61.3 \\
\hline & & \multirow{3}{*}{10} & 0 & 68.6 & 75.3 & 49.3 & 38.3 \\
\hline & & & 10 & 55.0 & 49.3 & 31.3 & 38.7 \\
\hline & & & 20 & 50.0 & 24.0 & 30.0 & 31.3 \\
\hline
\end{tabular}


TABLE 6. TABULATION OF CBR MEANS AND RANGES.

\begin{tabular}{|c|c|c|c|c|c|c|c|}
\hline \multirow{3}{*}{ 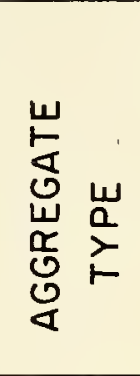 } & \multirow{3}{*}{ 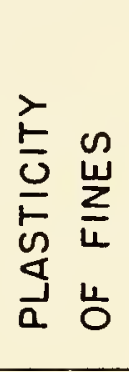 } & \multirow{3}{*}{ 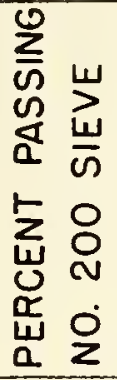 } & \multirow{3}{*}{ 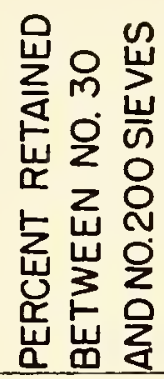 } & \multicolumn{4}{|c|}{ COMPACTION } \\
\hline & & & & \multicolumn{2}{|c|}{56 BLOWS } & \multicolumn{2}{|c|}{28 BLOWS } \\
\hline & & & & $\begin{array}{l}\text { CELL } \\
\text { MEAN } \bar{X}\end{array}$ & $\begin{array}{c}\text { RANGE } \\
R \\
\end{array}$ & $\begin{array}{l}\text { CELL } \\
\text { MEAN } \bar{X}\end{array}$ & $\begin{array}{c}\text { RANGE } \\
\mathrm{R}\end{array}$ \\
\hline \multirow{12}{*}{ 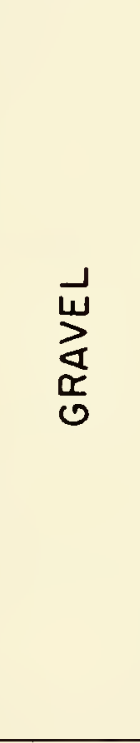 } & \multirow{6}{*}{3} & \multirow{3}{*}{5} & 0 & 53.4 & 13.3 & 39.8 & II.I \\
\hline & & & 10 & 92.8 & 7.9 & 43.8 & 11.0 \\
\hline & & & 20 & 47.0 & 3.9 & 74.3 & 2.0 \\
\hline & & \multirow{3}{*}{10} & 0 & 183.8 & 2.3 & 77.3 & 1.1 \\
\hline & & & 10 & 141.5 & 23.0 & 101.0 & 3.4 \\
\hline & & & 20 & 57.4 & 8.1 & 60.0 & 21.4 \\
\hline & \multirow{6}{*}{$\begin{array}{l}\frac{I}{U} \\
\frac{U}{I}\end{array}$} & \multirow{3}{*}{5} & 0 & 74.5 & 45.0 & 39.0 & 15.4 \\
\hline & & & 10 & 78.7 & 2.7 & 51.1 & 12.3 \\
\hline & & & 20 & 99.3 & 28.0 & 63.7 & 39.3 \\
\hline & & \multirow{3}{*}{10} & 0 & 740 & 28.0 & 38.0 & 10.7 \\
\hline & & & 10 & 28.4 & 3.3 & 27.7 & 8.7 \\
\hline & & & 20 & 34.7 & 18.7 & 25.0 & 6.0 \\
\hline \multirow{7}{*}{$\begin{array}{l}\text { w } \\
\text { o } \\
\text { i }\end{array}$} & \multirow{6}{*}{3} & \multirow{3}{*}{5} & 0 & 51.8 & 0.5 & 42.4 & 8.7 \\
\hline & & & 10 & 96.1 & 29.3 & 51.7 & 16.7 \\
\hline & & & 20 & 144.2 & 1.7 & 118.0 & 20.0 \\
\hline & & \multirow{3}{*}{10} & 0 & 100.7 & 1.4 & 55.7 & 18.0 \\
\hline & & & 10 & 136.4 & 16.7 & 84.4 & 28.7 \\
\hline & & & 20 & 143.3 & 40.0 & 111.0 & 28.6 \\
\hline & \multirow{6}{*}{$\frac{I}{O}$} & \multirow{3}{*}{5} & 0 & 65.8 & 28.4 & 31.0 & 12.6 \\
\hline \multirow{5}{*}{ 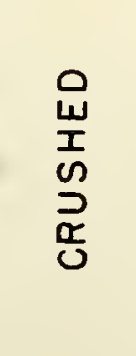 } & & & 10 & 90.3 & 7.2 & 76.9 & 6.7 \\
\hline & & & 20 & 119.4 & 1.3 & 57.3 & 8.0 \\
\hline & & \multirow{3}{*}{10} & 0 & 720 & 6.7 & 43.8 & 11.0 \\
\hline & & & 10 & 52.2 & 5.7 & 35.0 & 7.4 \\
\hline & & & 20 & 37.0 & 26.0 & 30.7 & 1.3 \\
\hline
\end{tabular}


where

$$
\begin{aligned}
& \mathrm{UCL}_{\mathrm{R}}=\text { upper control limit, } \\
& \mathrm{LCL}_{\mathrm{R}}=\text { lower control I imit, } \\
& \mathrm{D}_{4}=3.267 \\
& \mathrm{D}_{3}=0 \\
& \therefore \mathrm{UCL}_{\mathrm{R}}=3.267 \times 13.73=44.89 \\
& \mathrm{LCL}_{\mathrm{R}}=0 \times 13.73=0
\end{aligned}
$$

Only one range value is above the $\mathrm{UCL}_{R}$ of 44.89 . As all but one of the range values are below the critical upper control limit, the CBR dats satisfies the requirement of homogeneity of variance.

Figure 5 shows a plot of range values, $R$ va. cell mean, $\bar{x}$, values. The scatter of the plotted data indicates that there is no apparent correlation. Therefore, the data was not transformed before ANOVA computations.

For calculating ANOVA, BMD2V, a computer program for computing analysis of variance for factorial designs was utillzed. Before proceeding with an examination of the analysis of variance, it would be in order to define the following terms (17).

1. Main Effect. The main effect of a factor is a measure of the change in the response varlable to changes in the level of the factor averaged over all levels of all the other factors.

2. Interaction. It is the differential response to one factor in comblnation with varylng levels of a second factor applied 


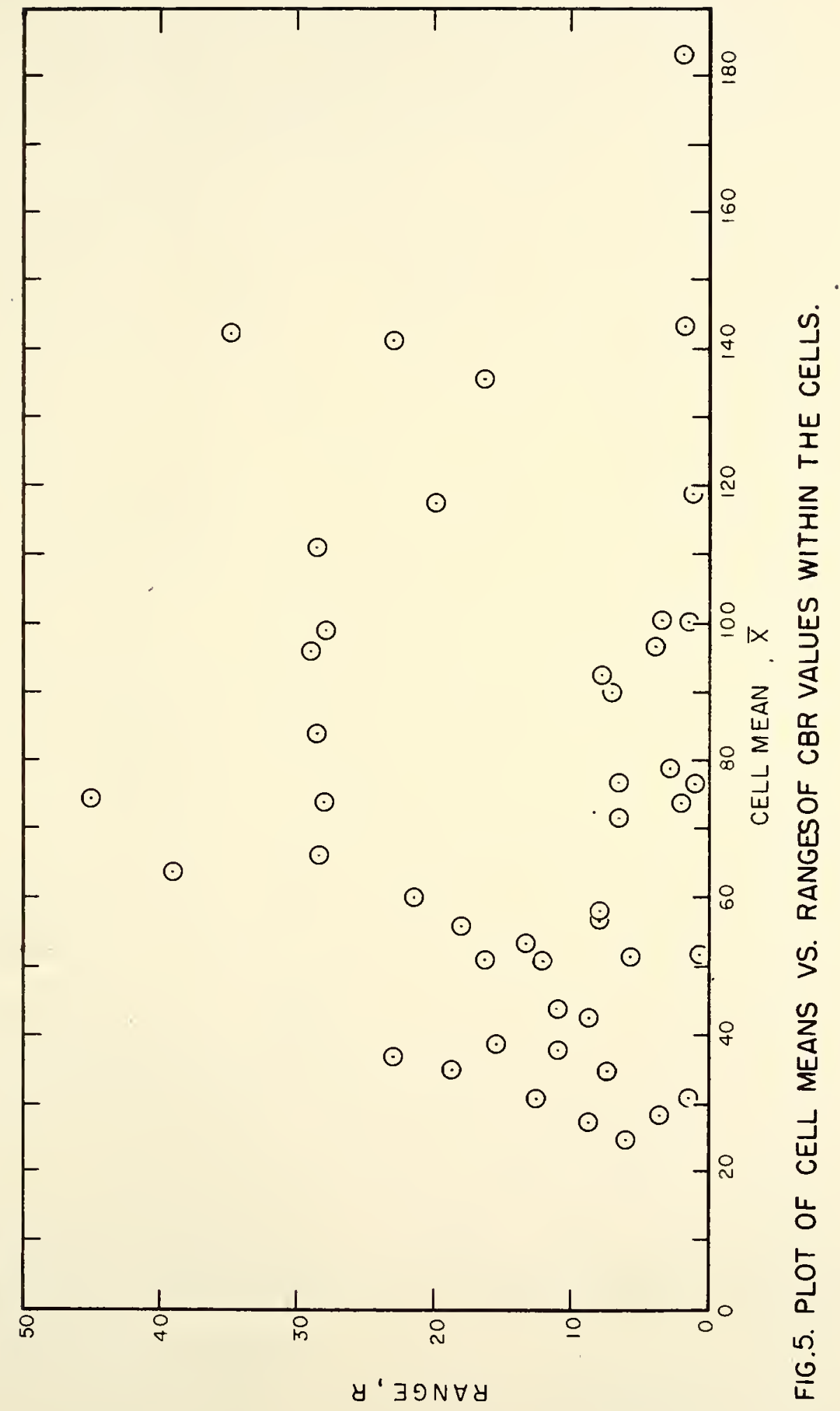


simultaneously. Interaction ts an additional effect due to the combined influence of two or more factors.

3. Significance. This indicates that the effect (main effect or Interaction) considered makes a major (non-zero) contribution to the variation in test results.

Table 7 summarizes the results of analyols of variance of the data presented in Table 5. Each main effect and interaction was tested for significance. This was accomplished by testing the ratio of the mean square for the effect under analysis and the experimental error mean square by means of the F-test. All effects were tested against experimental error. The tests were conducted at $\propto$-levels of 0.05 and 0.01 . Table 7 shows the results of these terto. In this tabulation, significance is indicated by the $\propto$-level at which the test was significant. A test that did not show significance is Indicated by the abbreviation 'NS'.

Level of significance ind fcates the probability of rejecting a hypothesis which is true. This would be best Lllustrated by an example. In the analysis of CBR data, consider the effect of aggregate type on the atrength characteristics of soll-aggregate mixtures as measured by the CBR test. To do this it is necessary to first set up a hypothesis. The hypothesis in this case would be that the effect of aggregate type on the strength characteristics of soilaggregate mixtures is not significant. This is known as the null hypothesis or the hypothesis of non-signiffcance. Statistically, this would be shown as,

$$
H_{0}: A_{i}=0 \quad(1=1,2) \quad \text { In equation } 6 .
$$


TABLE 7. SUMMARY OF ANALYSIS OF VARIANCE - CBR

\begin{tabular}{|c|c|c|c|c|c|c|c|}
\hline $\begin{array}{l}\text { SOURCE OF } \\
\text { VARIANCE }\end{array}$ & \begin{tabular}{|l|} 
DEGREES \\
OF \\
FREEDOM
\end{tabular} & $\begin{array}{l}\text { SUM OF } \\
\text { SOUARES }\end{array}$ & $\begin{array}{l}\text { MEAN } \\
\text { SOUARE }\end{array}$ & $\mathrm{F}$ & F.05 & $F_{01}$ & SIGNIFCANCE \\
\hline $\begin{array}{l}\text { AGGREGATE TYPE } \\
\text { (GRAVEL VS STONE), A }\end{array}$ & 1 & 1518.85 & 1518.85 & 956 & 4.04 & 7.19 & .OI LEVEL \\
\hline $\begin{array}{l}\text { PLASTICITY OF FINES } \\
\text { (LOW vS HIGH), }\end{array}$ & 1 & 27481.13 & 27481.13 & 17347 & 4.04 & 7.19 & .OI LEVEL \\
\hline $\begin{array}{l}\text { PERCENT PASSING } \\
\text { NO. } 200 \text { SIEVE, }\end{array}$ & 1 & 0.07 & 0.07 & 0.0004 & 4.04 & 7.19 & NS \\
\hline $\begin{array}{l}\text { PERCENT RETAINED } \\
\text { BETWEEN NO } 30 \text { AND } \\
\text { NO. } 200 \text { SIEVES, } \\
\end{array}$ & 2 & 3363.84 & 1681.92 & 10.61 & 319 & 508 & OI LEVEL \\
\hline $\begin{array}{l}\text { COMPACTION }(56 \\
\text { vs } 28 \text { BLOWS), F }\end{array}$ & 1 & 23177.29 & 2317729 & 146.30 & 404 & 719 & OI LEVEL \\
\hline INTERACTIONS AXB & I & 5483 & 54.83 & 0.35 & 4.04 & 7.19 & NS \\
\hline$A \times C$ & 1 & 293.48 & 293.48 & 1.85 & 4.04 & 7.19 & NS \\
\hline$\triangle \times D$ & 2 & 838077 & 4190.39 & 26.45 & $3.19^{\circ}$ & 508 & OI LEVEL \\
\hline$A \times F$ & 1 & 0.49 & 0.49 & 0.003 & 4.04 & 7.19 & NS \\
\hline $\mathrm{B} \times \mathrm{C}$ & 1 & 20188.35 & 20188.35 & 127.44 & 4.04 & 7.19 & OI LEVEL \\
\hline$B \times D$ & 2 & 2091.42 & 1045.71 & 6.60 & 3.19 & 5.05 & OI LEVEL \\
\hline$B \times F$ & 1 & 723.53 & 723.53 & 4.57 & 4.04 & 7.19 & O5 LEVEL \\
\hline$C \times D$ & 2 & 17130.30 & 1865.15 & 54.07 & 3.19 & 5.08 & .OILEVEL \\
\hline$C \times F$ & 1 & 0.25 & 0.25 & 0.002 & 4.04 & 7.19 & NS \\
\hline$D \times F$ & 2 & 856.27 & 42814 & 2.70 & 3.19 & 5.08 & NS \\
\hline$A \times B \times C$ & 1 & 425.67 & 425.67 & 2.69 & 4.04 & 7.19 & NS \\
\hline$A \times B \times D$ & 2 & 7069.30 & 353465 & 22.31 & 3.19 & 5.08 & OI LEVEL \\
\hline$A \times B \times F$ & 1 & 57.58 & 57.58 & 0.36 & 4.04 & 7.19 & NS \\
\hline$A \times C \times D$ & 2 & 1007.13 & 503.56 & 3.18 & 3.19 & 5.08 & NS \\
\hline$A \times C \times F$ & 1 & 1090 & 10.90 & 0.07 & 4.04 & 7.19 & NS \\
\hline$A \times D \times F$ & 2 & 1173.99 & 587.00 & 3.71 & 3.19 & 5.08 & .05 LEVEL \\
\hline$B \times C \times D$ & 2 & 2143.53 & 1071.77 & 6.77 & 3.19 & 5.08 & OI LEVEL \\
\hline$B \times C \times F$ & 1 & 2006.14 & 2006.14 & 12.66 & 4.04 & 719 & .OI LEVEL \\
\hline$B \times D \times F$ & 2 & 1648.71 & 824.36 & 520 & 3.19 & 5.08 & . OI LEVEL \\
\hline$C \times D \times F$ & 2 & 321567 & 1607.83 & 10.5 & 3.19 & 508 & OI LEVEL \\
\hline$A \times B \times C \times D$ & 2 & 1986.01 & 993.01 & 6.63 & 3.19 & 5.08 & .OI LEVEL \\
\hline$A \times B \times C \times F$ & 1 & 0.49 & 0.49 & 0.003 & 4.04 & 7.19 & NS \\
\hline$A \times B \times D \times F$ & 2 & 382.04 & 191.02 & 1.21 & 3.19 & 5.08 & NS \\
\hline$A \times C \times D \times F$ & 2 & 780.67 & 390.33 & 2.46 & 3.19 & 5.08 & NS \\
\hline$B \times C \times D \times F$ & 2 & 809.59 & 404.80 & 256 & 3.19 & 5.08 & NS \\
\hline$A \times B \times C \times D \times F$ & 2 & 806.87 & 403.43 & 2.55 & 3.19 & 5.08 & NS \\
\hline $\begin{array}{l}\text { ERROR WITHIN } \\
\text { REPLICATES, }\end{array}$ & 48 & 7604.10 & 158.42 & & & & \\
\hline TOTAL & 95 & 136389.24 & & & & & \\
\hline
\end{tabular}


where

$$
A_{1}=\text { aggregate type. }
$$

The next step is to test this hypothesis. This is done by using the F-test as shown in Table 7. The F-test indicates that the hypothesis should be rejected at one percent signiticant level. If the hypothesis of non-significance were true it would be rejected, on the average, only one percent of the time. In other words, there is, on the average, one percent chance of rejecting the null hypothesis incorrect1y. This test indicates, then, that there is strong evidence that aggregate type has a significant effect on the strength properties of soil-aggregate mixtures.

All other main effects and interactions were tested in a similar way. For each of these effects, a null hypothesis, similar to the one shown for the effect of aggregate type, was formulated. This approach holds true for all analyses of variance in this study. An examination of the results of the analysis of variance of CBR test data at one percent significant level reduces the model given by equation 6 to:

$$
\begin{aligned}
Y_{i j k l m n}= & U+A_{i}+B_{j}+D_{1}+F_{m}+A_{i l}+B C_{j k}+B_{j l} \\
& +C D_{k l}+A_{i j l}+B C D_{j k l}+B C F_{j k m}+B D F_{j l m} \\
& +C D F_{k l m}+A B C D_{i j k l}+E_{n(i j k l m)}
\end{aligned}
$$

A study of the main effects and interactions indicates the following:

1. The aggregate type had a significant effect on the strength characteristics of soll-aggregate mixtures as measured by the CBR test. 
2. The CBR volues were affected by the amount of compaction used In molding test specimens.

3. The effect of plasticity of fines on CBR was significant.

4. The amount of material retained between the No. 30 and No. 200 sieves had a significant effect on stabllity of soil-aggregate mixtures as measured by the CBR test. That 1s, the effect of skip grading on stablitty of soil aggregate mixtures was slgnificant.

5. Though within the studied range the effect of percent material passing the No. 200 sleve on CBR values was not significant, the effect of the interaction of this factor wth the percent aterlal retained between the No. 30 and No. 200 sieves $\left(C D_{k l}\right)$, was signiflcant. This indicates that there is a definite interplay between stability characteristics and the dust ratio. In this study, dust ratto is defined as:

$$
\text { Dust Ratio }=\frac{\text { Percent Materlal Pasaing No. } 200 \text { sieve }}{\text { Percent Material Passing No. } 30 \text { gieve. }}
$$

6. The interactions of percent material retained between the No. 30 and No. 200 sieves with each of the factors, aggregate type and plasticity of fines, $\left(A D_{11}, B D_{j 1}\right)$, tested eignificant.

7. The interaction of plasticlty of fines and the amount of fines $\left(B C_{j k}\right)$ was aignificant in its effect on $C B R$ values.

8. The three and higher factor interactions, shown to be significant, were mostly due to a relatively small error 
mean square. This is not unusual when a large number of factors are used in a factorial analysis. The significance of such interactions is relatively difficult to analyze. However, the presence of such high order interactions dictates that the data be more closely studied in order to further clarify and substantiate the significance of various effects and interactions.

In order to evaluace the effect of varying the amount of material letained between the No. 30 and No. 200 steves on stability of soilaggregate mixtures, the following model was formulated:

$$
\mathrm{Y}_{1 \mathrm{n}}=\mathrm{U}+\mathrm{D}_{1}+\mathrm{E}_{\mathrm{n}(1)}
$$

where

$$
\begin{aligned}
& Y_{1 n}=\text { CBR value obtained from a given test, } \\
& U=\text { true mean value for the population, } \\
& D_{1}=\text { true differential effect of percent retained between } \\
& \text { the No. } 30 \text { and No. } 200 \text { steves, with } 1=1,2,3, \\
& E_{n(1)=} \text { true exror effect of replicates with } n=1,2 .
\end{aligned}
$$

To use this model, the CBR data was divided into 16 groups, each group being a unlque combination of one distinct level of each of the other four factors, 1.e., aggregate type, plasticity of fines, percent passing No. 200 sieve, and compaction. Table 8 gives a summary of test data, one-way analysis of variance, and the result of the F-test at five percent significant level for each of these 16 data groups. An examination of the one-way analyses of varlance indicates that the effect of varying the amount of material retained 
TABLE 8. SUMMARY OF ONE-WAY ANALYSIS OF VARIANCE - CBR.

GRAVEL

LOW PI FINES

$5 \%$ PASSING NO. 200 SIEVE

56 BLOW COMPACTION

ONE-WAY ANOVA

\begin{tabular}{|c|cc|}
\hline $\begin{array}{l}\text { PERCENT RETAINED } \\
\text { BETWEEN NO.30 AND } \\
\text { NO. 2OO SIEVES }\end{array}$ & $\begin{array}{c}\text { C BR } \\
\text { (PERCENT) }\end{array}$ \\
\hline 0 & 60.0 & 46.7 \\
\hline 10 & 88.8 & 96.7 \\
\hline 20 & 98.9 & 95.0 \\
\hline
\end{tabular}

\begin{tabular}{|c|c|c|c|c|c|c|}
\hline $\begin{array}{l}\text { SOURCE OF } \\
\text { VARIATION }\end{array}$ & $\begin{array}{l}\text { DEGREES OF } \\
\text { FREEDOM }\end{array}$ & $\begin{array}{l}\text { SUM OF } \\
\text { SQUARES }\end{array}$ & $\begin{array}{l}\text { MEAN } \\
\text { SQUARE }\end{array}$ & F & F.05 & SIGNIFICANCE \\
\hline $\begin{array}{l}\text { PERCENT BETWEEN } \\
\text { NO. 30-NO.200 }\end{array}$ & 2 & 2313.9733 & $1156: 967$ & 272756 & 9.55 & SIGNIFICANT \\
\hline ERROR & 3 & 1272550 & 42.4183 & & & \\
\hline TOIAL & 5 & 2441.2283 & 1199.3853 & & & \\
\hline
\end{tabular}

GRAVEL

LOW PI FINES

$5 \%$ PASSING NO. 200 SIEVE

28 BLOW COMPACTION

ONE - WAY ANOVA

\begin{tabular}{|c|cc|}
\hline $\begin{array}{c}\text { PERCENT RETAINED } \\
\text { BETWEEN NO 30 AND } \\
\text { NO. 200 SIEVES }\end{array}$ & $\begin{array}{c}\text { C 8 R } \\
\text { (PERCENT) }\end{array}$ \\
\hline 0 & 45.3 & 34.2 \\
\hline 10 & 38.3 & 493 \\
\hline 20 & 73.3 & 74.3 \\
\hline
\end{tabular}

\begin{tabular}{|c|c|c|c|c|c|c|}
\hline $\begin{array}{l}\text { SOURCE OF } \\
\text { VARIATION }\end{array}$ & $\begin{array}{l}\text { DEGREESOF } \\
\text { FREEDOM }\end{array}$ & $\begin{array}{l}\text { SUM OF } \\
\text { SQUARES }\end{array}$ & $\begin{array}{l}\text { MEAN } \\
\text { SQUARE }\end{array}$ & $F$ & F.05 & SIGNIFICANCE \\
\hline $\begin{array}{l}\text { PERCENT BETWEEN } \\
\text { NO 30- NO. 200 }\end{array}$ & 2 & 1426.9033 & 713.4517 & 172463 & 9.55 & SIGNIFICANT \\
\hline ERROR & 3 & 124.1050 & 41.3683 & & & \\
\hline TOTAL & 5 & 1551.0083 & 754.8200 & & & \\
\hline
\end{tabular}


TABLE 8 , CONT.

GRAVEL

LOW PI FINES

$10 \%$ PASSING NO. 200 SIEVE

56 BLOW COMPACTION

\begin{tabular}{|c|cc|}
\hline $\begin{array}{l}\text { PERCENT RETAINED } \\
\text { BETWEEN NO. 30 AND } \\
\text { NO. 200 SIEVES }\end{array}$ & $\begin{array}{c}\text { C B R } \\
\text { (PERCENT) }\end{array}$ \\
\hline 0 & 1849 & 182.6 \\
\hline 10 & 1300 & 153.0 \\
\hline 20 & 61.4 & 53.3 \\
\hline
\end{tabular}

ONE-WAY ANOVA

\begin{tabular}{|c|c|c|c|c|c|c|}
\hline $\begin{array}{l}\text { SOURCE OF } \\
\text { VARIATION }\end{array}$ & $\begin{array}{l}\text { DEGREES OF } \\
\text { FREEDOM }\end{array}$ & $\begin{array}{l}\text { SUM OF } \\
\text { SOUARES }\end{array}$ & $\begin{array}{l}\text { MEAN } \\
\text { SQUARE }\end{array}$ & $F$ & F O5 & SIGNIFICANCE \\
\hline $\begin{array}{l}\text { PERCENT BETWEEN } \\
\text { NO 30-NO.200 }\end{array}$ & 2 & 16562.1633 & 8281.0817 & 82.8246 & 9.55 & SIGNIFICANT \\
\hline ERROR & 3 & 299.9500 & 999833 & & & \\
\hline TOTAL & 5 & 16862.1133 & 8381.0650 & & & \\
\hline
\end{tabular}

GRAVEL

LOW PI FINES

$10 \%$ PASSING NO. 200 SIEVE 28 BLOW COMPACTION

ONE-WAY ANOVA

\begin{tabular}{|c|cc|}
\hline $\begin{array}{c}\text { PERCENT RETAINED } \\
\text { BETWEEN NO.3OAND } \\
\text { NO. 200 SIEVES }\end{array}$ & \multicolumn{2}{|c|}{ CBR } \\
\hline 0 & 76.7 & 77.8 \\
\hline 10 & 102.7 & 99.3 \\
\hline 20 & 493 & 70.7 \\
\hline
\end{tabular}

\begin{tabular}{|c|c|c|c|c|c|c|}
\hline $\begin{array}{l}\text { SOURCE OF } \\
\text { VARIATION }\end{array}$ & $\begin{array}{l}\text { DEGREESOF } \\
\text { FREEDOM }\end{array}$ & $\begin{array}{l}\text { SUM OF } \\
\text { SQUARES }\end{array}$ & $\begin{array}{l}\text { MEAN } \\
\text { SOUARE }\end{array}$ & $F$ & $F$.05 & SIGNIFICANCE \\
\hline $\begin{array}{l}\text { PERCENT BETWEEN } \\
\text { NO 3O - NO.200 }\end{array}$ & 2 & 1695.0833 & 847.5417 & 10.8029 & 955 & SIGNIFICANT \\
\hline ERROR & 3 & 235.3650 & 78.4550 & & & \\
\hline TOTAL & 5 & 1930.4483 & 925.9967 & & & \\
\hline
\end{tabular}


TABLE 8 , CONT.

GRAVEL

HIGH PI FINES

5\% PASSING NO. 200 SIEVE

56 BLOW COMPACTION

\section{ONE-WAY ANOVA}

\begin{tabular}{|c|cc|}
\hline $\begin{array}{c}\text { PERCENT RETAINED } \\
\text { BETWEEN NO. 30 AND } \\
\text { NO. 200 SIEVES }\end{array}$ & \multicolumn{2}{|c|}{$\begin{array}{c}\text { CB R R } \\
\text { (PERCENT) }\end{array}$} \\
\hline 0 & 97.0 & 52.0 \\
\hline 10 & 77.3 & 80.0 \\
\hline 20 & 113.3 & 85.3 \\
\hline
\end{tabular}

\begin{tabular}{|c|c|c|c|c|c|c|}
\hline $\begin{array}{l}\text { SOURCE OF } \\
\text { VARIATION }\end{array}$ & $\begin{array}{l}\text { DEGREES OF } \\
\text { FREEDOM }\end{array}$ & $\begin{array}{l}\text { SUM OF } \\
\text { SOUARES }\end{array}$ & $\begin{array}{l}\text { MEAN } \\
\text { SQUARE }\end{array}$ & $F$ & F.05 & SIGNIFICANCE \\
\hline $\begin{array}{l}\text { PERCENT BETWEEN } \\
\text { NO. 3O-NO.200 }\end{array}$ & 2 & 705.7900 & 352.8950 & .7518 & 955 & N.S. \\
\hline ERROR & 3 & 1408.1450 & 469.3817 & & & \\
\hline TOTAL & 5 & 2113.9350 & 8222767 & & & \\
\hline
\end{tabular}

GRAVEL

HIGH PI FINES

$5 \%$ PASSING NO. 200 SIEVE

28 BLOW COMPACTION

ONE-WAY ANOVA

\begin{tabular}{|c|cc|}
\hline $\begin{array}{l}\text { PERCENT RETAINED } \\
\text { BETWEEN NO. 30 AND } \\
\text { NO. 200 SIEVES }\end{array}$ & \multicolumn{2}{|c|}{$\begin{array}{c}\text { C B R } \\
\text { (PERCENT) }\end{array}$} \\
\hline 0 & 467 & 31.3 \\
\hline 10 & 5725 & 45.0 \\
\hline 20 & 44.0 & 83.3 \\
\hline
\end{tabular}

\begin{tabular}{|c|c|c|c|c|c|c|}
\hline $\begin{array}{l}\text { SOURCE OF } \\
\text { VARIATION }\end{array}$ & $\begin{array}{l}\text { DEGREESOF } \\
\text { FREEDOM }\end{array}$ & $\begin{array}{l}\text { SUM OF } \\
\text { SOUARES }\end{array}$ & $\begin{array}{l}\text { MEAN } \\
\text { SOUARE }\end{array}$ & $F$ & F .05 & SIGNIFICANCE \\
\hline $\begin{array}{l}\text { PERCENT 8ETWEEN } \\
\text { NO.30-NO.200 }\end{array}$ & 2 & 607.6758 & 303.8379 & .9437 & 9.55 & N.S. \\
\hline ERROR & 3 & 965.8563 & 321.9521 & & & \\
\hline TOTAL & 5 & 1573.5321 & 625.7900 & & & \\
\hline
\end{tabular}


TABLE 8, CONT.

GRAVEL

HIGH PI FINES

$10 \%$ PASSING NO. 200 SIEVE

56 BLOW COMPACTION

\begin{tabular}{|c|cc|}
\hline $\begin{array}{c}\text { PERCENT RETAINED } \\
\text { BETWEEN NO.3O AND } \\
\text { NO. 200 SIEVES }\end{array}$ & $\begin{array}{c}\text { CBR } \\
\text { (PERCENT) }\end{array}$ \\
\hline 0 & 88.0 & 600 \\
\hline 10 & 300 & 26.7 \\
\hline 20 & 25.3 & 440 \\
\hline
\end{tabular}

ONE-WAY ANOVA

\begin{tabular}{|c|c|c|c|c|c|c|}
\hline $\begin{array}{l}\text { SOURCE OF } \\
\text { VARIAT ION }\end{array}$ & $\begin{array}{l}\text { OEGREES OF } \\
\text { FREEDOM }\end{array}$ & $\begin{array}{l}\text { SUM OF } \\
\text { SQUARES }\end{array}$ & $\begin{array}{l}\text { MEAN } \\
\text { SOUARE }\end{array}$ & F & F O5 & SIGNIFICANCE \\
\hline $\begin{array}{l}\text { PERCENT BETWEEN } \\
\text { NO 30-NO.20O }\end{array}$ & 2 & 2448.0233 & 1224.0117 & 64167 & 955 & N.S. \\
\hline ERROR & 3 & 572.2900 & 190.7633 & & & \\
\hline TOTAL & 5 & 30203133 & 1414.7750 & & & \\
\hline
\end{tabular}

GRAVEL

HIGH PI FINES

$10 \%$ PASSING NO.200SIEVE

28 BLOW COMPACTION

ONE-WAY ANOVA

\begin{tabular}{|c|cc|}
\hline $\begin{array}{l}\text { PERCENT RETAINED } \\
\text { BETWEEN NO 30 AND } \\
\text { NO 200 SIEVES }\end{array}$ & $\begin{array}{c}\text { C B R } \\
\text { (PERCENT) }\end{array}$ \\
\hline 0 & 433 & 326 \\
\hline 10 & 32.0 & 23.3 \\
\hline 20 & 22.0 & 280 \\
\hline
\end{tabular}

\begin{tabular}{|c|c|c|c|c|c|c|}
\hline $\begin{array}{l}\text { SOURCE OF } \\
\text { VARIATION }\end{array}$ & $\begin{array}{l}\text { DEGREESOF } \\
\text { FREEDOM }\end{array}$ & $\begin{array}{l}\text { SUM OF } \\
\text { SOUARES }\end{array}$ & $\begin{array}{l}\text { MEAN } \\
\text { SOUARE }\end{array}$ & $F$ & F.05 & SIGNIFICANCE \\
\hline $\begin{array}{l}\text { PERCENT BETWEEN } \\
\text { NO.3O-NO 200 }\end{array}$ & 2 & 187.2100 & 93.6050 & 2.4831 & 9.55 & N.S. \\
\hline ERROR & 3 & 1130900 & 37.6967 & & & \\
\hline TOTAL & 5 & 300.3000 & 131.3017 & & & \\
\hline
\end{tabular}


TABLE 8, CONT.

CRUSHED STONE

LOW PI FINES

$5 \%$ PASSING NO. 200 SIEVE

56 BLOW COMPACTION

ONE-WAY ANOVA

\begin{tabular}{|c|c|c|c|c|c|c|}
\hline $\begin{array}{l}\text { SOURCE OF } \\
\text { VARIATION }\end{array}$ & $\begin{array}{l}\text { DEGREES OF } \\
\text { FREEDOM }\end{array}$ & $\begin{array}{l}\text { SUM OF } \\
\text { SOUARES }\end{array}$ & $\begin{array}{l}\text { MEAN } \\
\text { SQUARE }\end{array}$ & F & F O5 & SIGNIFICANCE \\
\hline $\begin{array}{c}\text { PERCENT BETWEEN } \\
\text { NO. } 30-N O .200\end{array}$ & 2 & 8542.5733 & 4271.2867 & 29.7433 & 9.55 & SIGNIFICANT \\
\hline ERROR & 3 & 430.8150 & 143.6050 & & & \\
\hline TOTAL & 5 & 8973.3883 & 4414.8917 & & & \\
\hline
\end{tabular}

\begin{tabular}{|c|cc|}
\hline $\begin{array}{l}\text { PERCENT RETAINED } \\
\text { BETWEEN NO.30 AND } \\
\text { NQ 20O SIEVES }\end{array}$ & $\begin{array}{c}\text { C B R } \\
\text { (PERCENT) }\end{array}$ \\
\hline 0 & 52.0 & 51.5 \\
\hline 10 & 110.7 & 81.4 \\
\hline 20 & 143.3 & 145.0 \\
\hline
\end{tabular}

CRUSHED STONE

LOW PI FINES

$5 \%$ PASSING NO. 200 SIEVE 28 BLOW COMPACTION

ONE - WAY ANOVA

\begin{tabular}{|c|cc|}
\hline $\begin{array}{l}\text { PERCENT RETAINED } \\
\text { BETWEEN NO.3O AND } \\
\text { NO. 200 SIEVES }\end{array}$ & $\begin{array}{c}\text { C B R } \\
\text { (PERCENT) }\end{array}$ \\
\hline 0 & 46.7 & 38.0 \\
\hline 10 & 43.3 & 60.0 \\
\hline 20 & 1280 & 108.0 \\
\hline
\end{tabular}

\begin{tabular}{|c|c|c|c|c|c|c|}
\hline $\begin{array}{l}\text { SOURCE OF } \\
\text { VARIATION }\end{array}$ & $\begin{array}{l}\text { DEGREESOF } \\
\text { FREEDOM }\end{array}$ & $\begin{array}{l}\text { SUM OF } \\
\text { SQUARES }\end{array}$ & $\begin{array}{l}\text { MEAN } \\
\text { SQUARE }\end{array}$ & $F$ & F .05 & SIGNIFICANCE \\
\hline $\begin{array}{l}\text { PERCENT BETWEEN } \\
\text { NO. 30 - NO.200 }\end{array}$ & 2 & 6807.8233 & 3403.9117 & 27.0660 & 9.55 & SIGNIFICANT \\
\hline ERROR & 3 & 377.2900 & 125.7633 & & & \\
\hline TOTAL & 5 & 7185.1133 & 3529.6750 & & & \\
\hline
\end{tabular}


TABLE 8, CONT.

CRUSHED STONE

LOW PI FINES

$10 \%$ PASSING NO. 200 SIEVE

56 BLOW COMPACTION

\begin{tabular}{|c|cc|}
\hline $\begin{array}{l}\text { PERCENT RETAINED } \\
\text { BETWEEN NO.3O AND } \\
\text { NO. 200 SIEVES }\end{array}$ & $\begin{array}{c}\text { C B R } \\
\text { (PERCENT) }\end{array}$ \\
\hline 0 & 101.4 & 1000 \\
\hline 10 & 128.0 & 144.7 \\
\hline 20 & 123.3 & 1633 \\
\hline
\end{tabular}

ONE-WAY ANOVA

\begin{tabular}{|c|c|c|c|c|c|c|}
\hline $\begin{array}{l}\text { SOURCE OF } \\
\text { VARIATION }\end{array}$ & $\begin{array}{l}\text { DEGREES OF } \\
\text { FREEDOM }\end{array}$ & $\begin{array}{l}\text { SUM OF } \\
\text { SQUARES }\end{array}$ & $\begin{array}{l}\text { MEAN } \\
\text { SQUARE }\end{array}$ & F & F O5 & SIGNIFICANCE \\
\hline $\begin{array}{c}\text { PERCENT BETWEEN } \\
\text { NO 30 -NO.200 }\end{array}$ & 2 & 2089.3233 & 10446617 & 33325 & 9.55 & N S \\
\hline ERROR & 3 & 940.4250 & 313.4750 & & & \\
\hline TOTAL & 5 & 3029.7483 & 1358.1367 & & & \\
\hline
\end{tabular}

CRUSHED STONE

LOW PI FINES

$10 \%$ PASSING NO. 200 SIEVE

28 BLOW COMPACTION

ONE-WAY ANOVA

\begin{tabular}{|c|cc|}
\hline $\begin{array}{l}\text { PERCENT RETAINED } \\
\text { BET WEEN NO. 3OAND } \\
\text { NO 200 SIEVES }\end{array}$ & \multicolumn{2}{|c|}{$\begin{array}{c}\text { C 8 R } \\
\text { (PERCENT) }\end{array}$} \\
\hline 0 & 46.7 & 64.7 \\
\hline 10 & 987 & 700 \\
\hline 20 & 125.3 & 96.7 \\
\hline
\end{tabular}

\begin{tabular}{|c|c|c|c|c|c|c|}
\hline $\begin{array}{l}\text { SOURCE OF } \\
\text { VARIATION }\end{array}$ & $\begin{array}{l}\text { DEGREESOF } \\
\text { FREEDOM }\end{array}$ & $\begin{array}{l}\text { SUM OF } \\
\text { SQUARES }\end{array}$ & $\begin{array}{l}\text { MEAN } \\
\text { SQUARE }\end{array}$ & $F$ & $F_{\text {OO5 }}$ & SIGNIFICANCE \\
\hline $\begin{array}{l}\text { PERCENT BETWEEN } \\
\text { NO 30 - NO.200 }\end{array}$ & 2 & 3059.4233 & 1529.7117 & 4.6693 & 955 & N.S. \\
\hline ERROR & 3 & 982.8250 & 327.6083 & & & \\
\hline TOTAL & 5 & 4042.2483 & 1857.3200 & & & \\
\hline
\end{tabular}


TABLE 8 , CONT.

CRUSHED STONE

HIGH PI FINES

$5 \%$ PASSING NO. 200 SIEVE

56 BLOW COMPACTION

\begin{tabular}{|c|cc|}
\hline $\begin{array}{c}\text { PERCENT RETAINED } \\
\text { BETWEEN NO.3O AND } \\
\text { NO 200 SIEVES }\end{array}$ & \multicolumn{2}{|c|}{$\begin{array}{c}\text { CBR } \\
\text { (PERCENT) }\end{array}$} \\
\hline 0 & 800 & 51.6 \\
\hline 10 & 93.9 & 86.7 \\
\hline 20 & 118.7 & 1200 \\
\hline
\end{tabular}

ONE -WAY ANOVA

\begin{tabular}{|c|c|c|c|c|c|c|}
\hline $\begin{array}{l}\text { SOURCE OF } \\
\text { VARIATION }\end{array}$ & $\begin{array}{l}\text { DEGREES OF } \\
\text { FREEDOM }\end{array}$ & $\begin{array}{l}\text { SUM OF } \\
\text { SQUARES }\end{array}$ & $\begin{array}{l}\text { MEAN } \\
\text { SQUARE }\end{array}$ & $F$ & F.05 & SIGNIFICANCE \\
\hline $\begin{array}{l}\text { PERCENT BETWEEN } \\
\text { NO 3O-NO 200 }\end{array}$ & 2 & 28745033 & 14372517 & 10.0263 & 955 & SIGNIFICANT \\
\hline ERROR & 3 & 430.0450 & 143.3483 & & & \\
\hline TOTAL & 5 & 33045483 & 286.6000 & & & \\
\hline
\end{tabular}

CRUSHEO STONE

HIGH PI FINES

$5 \%$ PASSING NO. 200 SIEVE

28 BLOW COMPACTION

ONE - WAY ANOVA

\begin{tabular}{|c|cc|}
\hline $\begin{array}{l}\text { PERCENT RETAINED } \\
\text { 8ETWEEN NO.3OAND } \\
\text { NO. 200 SIEVES }\end{array}$ & $\begin{array}{c}\text { CBR } \\
\text { (PERCENT) }\end{array}$ \\
\hline 0 & 373 & 247 \\
\hline 10 & 800 & 737 \\
\hline 20 & 533 & 61.3 \\
\hline
\end{tabular}

\begin{tabular}{|c|c|c|c|c|c|c|}
\hline $\begin{array}{l}\text { SOURCE OF } \\
\text { VARIATION }\end{array}$ & $\begin{array}{l}\text { DEGREESOF } \\
\text { FREEDOM }\end{array}$ & $\begin{array}{l}\text { SUM OF } \\
\text { SQUARES }\end{array}$ & $\begin{array}{l}\text { MEAN } \\
\text { SOUARE }\end{array}$ & $F$ & $F$.05 & SIGNIFICANCE \\
\hline $\begin{array}{l}\text { PERCENT BETWEEN } \\
\text { NO. 30 - NO.200 }\end{array}$ & 2 & 2117.4100 & 1058.7050 & 242036 & 9.55 & SIGNIFICANT \\
\hline ERROR & 3 & 131.2250 & 43.7417 & & & \\
\hline TOTAL & 5 & 22486350 & 11024467 & & & \\
\hline
\end{tabular}


TABLE 8, CONT.

CRUSHED STONE

HIGH PI FINES

$10 \%$ PASSING NO. 200 SIEVE

56 BLOW COMPACTION

\begin{tabular}{|c|cc|}
\hline $\begin{array}{l}\text { PERCENT RETAINED } \\
\text { BETWEEN NO. 30 AND } \\
\text { NO. 200 SIEVES }\end{array}$ & \multicolumn{2}{|c|}{$\begin{array}{c}\text { C B R } \\
\text { (PERCENT) }\end{array}$} \\
\hline 0 & 68.6 & 75.3 \\
\hline 10 & 55.0 & 49.3 \\
\hline 20 & 50.0 & 24.0 \\
\hline
\end{tabular}

ONE - WAY ANOVA

\begin{tabular}{|c|c|c|c|c|c|c|}
\hline $\begin{array}{l}\text { SOURCE OF } \\
\text { VARIATION }\end{array}$ & $\begin{array}{l}\text { DEGREES OF } \\
\text { FREEDOM }\end{array}$ & $\begin{array}{l}\text { SUM OF } \\
\text { SQUARES }\end{array}$ & $\begin{array}{l}\text { MEAN } \\
\text { SQUARE }\end{array}$ & F & F O5 & SIGNIFICANCE \\
\hline $\begin{array}{l}\text { PERCENT BETWEEN } \\
\text { NO. 30-NO 200 }\end{array}$ & 2 & 1228.7100 & 614.3550 & 48928 & 9.55 & N.S. \\
\hline ERROR & 3 & 376.6900 & 125.5633 & & & \\
\hline TOTAL & 5 & 1605.4000 & 739.9183 & & & \\
\hline
\end{tabular}

CRUSHED STONE

HIGH PI FINES

$10 \%$ PASSING NO. 200 SIEVE

28 BLOW COMPACTION

ONE-WAY ANOVA

\begin{tabular}{|c|cc|}
\hline $\begin{array}{l}\text { PERCENT RETAINED } \\
\text { BETWEEN NO.3O AND } \\
\text { NO. 200 SIEVES }\end{array}$ & $\begin{array}{c}\text { C BR } \\
\text { (PERCENT) }\end{array}$ \\
\hline 0 & 49.3 & 38.3 \\
\hline 10 & 31.3 & 38.7 \\
\hline 20 & 300 & 31.3 \\
\hline
\end{tabular}

\begin{tabular}{|c|c|c|c|c|c|c|}
\hline $\begin{array}{l}\text { SOURCE OF } \\
\text { VARIATION }\end{array}$ & $\begin{array}{l}\text { DEGREESOF } \\
\text { FREEDOM }\end{array}$ & $\begin{array}{l}\text { SUM OF } \\
\text { SQUARES }\end{array}$ & $\begin{array}{l}\text { MEAN } \\
\text { SQUARE }\end{array}$ & $F$ & F O5 & SIGNIFICANCE \\
\hline $\begin{array}{l}\text { PERCENT BET WEEN } \\
\text { NO. 30 - NO. 200 }\end{array}$ & 2 & 179.5233 & 89.7617 & 3.0351 & 9.55 & N.S. \\
\hline ERROR & 3 & 88.7250 & 29.5750 & & & \\
\hline TOTAL & 5 & 268.2483 & 119.3367 & & & \\
\hline
\end{tabular}


between the No. 30 and No. 200 sieves was significant at the five percent level for the following conditions:

1. gravel, low PI fines, five percent passing No. 200 sieve, 56-blow compaction;

2. gravel, low PI flnes, five percent passing No. 200 sieve, 28-blow compaction;

3. grave1, low PI fines, ten percent passing No. 200 sieve, 56-blow compaction;

4. gravel, Low PI fines, cen percent passing No. 200 sieve, 28-blow compaction;

5. crushed stone, low PI fines, five percent passing No. 200 sieve, 56-blow compaction;

6. crushed stone, low PI fines, flve percent passing No. 200 sieve, 28-blow compaction;

7. crushed stone, high PI fines, five percent passing No. 200 sleve, 56-blow compaction;

8. crushed stone, high PI fines, five percent passing No. 200 sieve, 28-blow compaction.

This analysis shows that the percent of material retained between the No. 30 and No. 200 sieves had a significant effect on strength characteristics of all soil-gravel mixes with low PI fines irrespective of the compaction level or the percent material passing the No. 200 sleve. In case of soil-crushed stone mixes, the effect of percent material retained between the No. 30 and No. 200 sleves was significant only in case of mixes with five percent materisl passing the No. 200 sieve, frrespective of the plasticity of fines or the compaction level. 


\section{Texas Triaxial Test Data}

The analysis of variance models assumed for analyzing Texas triaxial test data are:

$$
\begin{aligned}
& Y^{\prime}{ }_{i k l}=U+A_{i}+C_{k}+D_{1}+A_{i k}+A D_{1 l}+C_{k l}+E_{(i k l)} \\
& Y^{\prime}{ }_{j k l}=U+B^{\prime}{ }_{j}+C_{k}+D_{1}+B^{\prime} C_{j k}+B^{\prime} D_{j l}+C_{k l}+E_{(j k l)} \\
& Y_{j k l}^{\prime \prime}=U+A_{i}+C_{k}+D_{1}+A C_{i k}+A D_{11}+C D_{k l}+E_{(i k l)} \\
& Y^{\prime \prime}{ }_{j k 1}=U+B^{\prime}{ }_{j}+C_{k}+D_{1}+B^{\prime} C_{j k}+B^{\prime} D_{j 1}+C D_{k 1}+E_{(j k l)}
\end{aligned}
$$

where

$$
\begin{aligned}
& Y^{\prime}{ }_{i k l}, Y^{\prime}{ }_{j k l}=\text { triaxial. compressive strength value obtalned } \\
& \text { from a Texa triaxial test, } \\
& Y^{\prime \prime}{ }_{i k 1}, Y^{\prime \prime}{ }_{j k l}=\text { value of angle of internal friction obtained } \\
& \text { from a Texas triaxial teat, } \\
& \text { v } \\
& \text { = true mean value for the population, } \\
& A_{1} \\
& =\text { true differential effect of aggregate type } \\
& \text { Gravel vs. clushed stone, both with low } \\
& \text { PI fines), } \\
& B^{\prime} j \quad=\quad t r u e \text { differentlal effect of plasticity of } \\
& \text { fines (low PI vs. NP in crushed stone mixes), } \\
& c_{k} \quad=\quad \text { true differential effect of percent passing } \\
& \text { No. } 200 \text { aieve (five percent vs, ten percent), } \\
& \mathrm{D}_{1} \quad=\text { true differential effect of percent retained } \\
& \text { between No. } 30 \text { and No. } 200 \text { steves, } \\
& E_{(i k 1)}, E_{(j k l)}=\text { true error effect. }
\end{aligned}
$$


The other terms denote interactions between the main effects. The subscilipts assume the values:

$$
\begin{aligned}
& 1=1,2 \\
& j=1,2 \\
& k=1,2 \\
& 1=1,2,3 .
\end{aligned}
$$

As equations $11,12,13$, and 14 denote non-replicated fixedeffect models, the error and the three-factor interaction $\left(A_{C D} D_{i k 1}\right)$ or $\left(\mathrm{BCD}_{j \mathrm{kl}}\right)$ are confounded, i.e., separate estimates of sum of squares error, E, and sum of squares ACD or BCD cannot be obtained.

The assumptions that underlie these models are homogeneity of variance, normality, additivity, and independence of errors. For unreplicated models, it is difficult to teat the validity of these assumptions. However, analysis of variance is a fairly robust statistical method and is relatively insensitive to violations of the assumptions of normality and homogeneity of variance.

Table 9 show the Texas triaxial teat data layout for analyses of variance. The models asumed for these analyses are given by equations 11 and 13. Table 10 summarizes the results of analysis of variance of the triaxial compressive strength data. Equation 11 gives the assumed analysis of variance model for this case. The results of the F-tests indicated that only the effect of aggregate type on triaxial compresaive strength was significant at the five percent level. Hence, equation 11 reduces to:

$$
Y_{1 k 1}^{\prime}=U+A_{1}+E_{(i k 1)}
$$


TABLE 9. SUMMARY OF TEXAS TRIAXIAL TEST DATA.

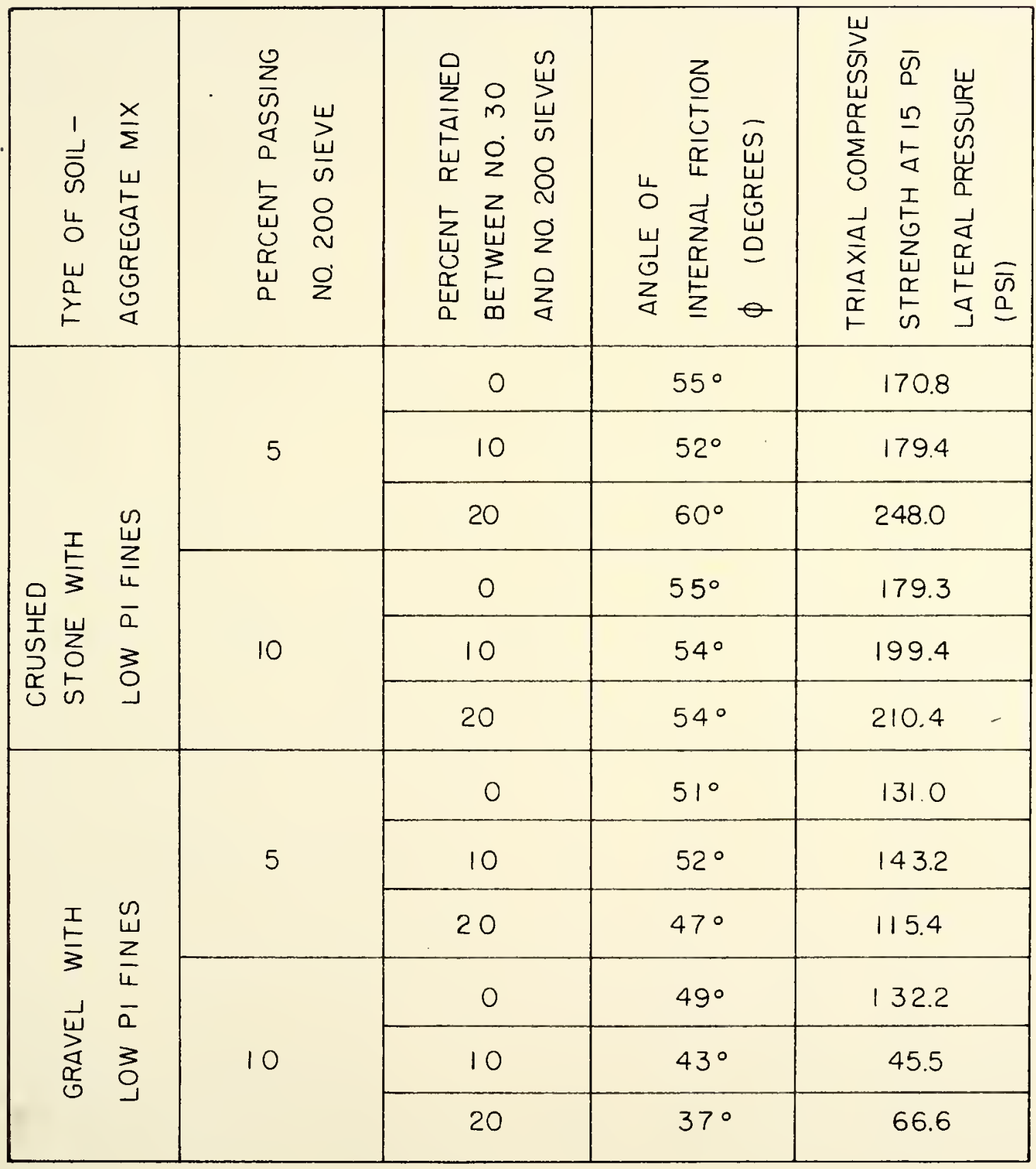


TABLE 10. SUMMARY OF ANALYSIS OF VARIANCE - TRIAXIAL COMPRESSIVE STRENGTH AT I5 PSI LATERAL PRESSURE.

\begin{tabular}{|c|c|c|c|c|c|c|c|}
\hline $\begin{array}{c}\text { SOURCE OF } \\
\text { VARIATION }\end{array}$ & $\begin{array}{l}\text { DEGREES } \\
\text { OF } \\
\text { FREEOM }\end{array}$ & $\begin{array}{l}\text { SUM OF } \\
\text { SQUARES }\end{array}$ & $\begin{array}{l}\text { MEAN } \\
\text { SOUARE }\end{array}$ & $F$ & $F_{.05}$ & $F_{10}$ & $\begin{array}{l}\text { SIGNI- } \\
\text { FICANCE }\end{array}$ \\
\hline $\begin{array}{c}\text { AGGREGATE TYPE } \\
\text { (STONE VSGRAVEU, A }\end{array}$ & 1 & 2167500 & 216.7500 & 388209 & 18.5 & 8.53 & $F_{05}$ \\
\hline $\begin{array}{c}\text { PERCENT PASSING } \\
\text { NO 2OO SIEVE, C }\end{array}$ & 1 & 56.33333 & 56.33333 & 10.0896 & 18.5 & 8.53 & $F_{.10}$ \\
\hline $\begin{array}{c}\text { PERCENT RETAINED } \\
\text { 8ETWEEN NO 3OAND } \\
\text { NO. 2OO SIEVES, D }\end{array}$ & 2 & 1616667 & 808333 & 14478 & 190 & 992 & N S \\
\hline $\begin{array}{c}\text { INTERACTIONS } \\
\text { AXC C }\end{array}$ & 1 & 24.08333 & 2408333 & 43134 & 185 & 853 & N S \\
\hline A X D & 2 & 635000 & 317500 & 56866 & 19.0 & 992 & N.S \\
\hline C X D & 2 & 22.1667 & 11.08333 & 1.9851 & 19.0 & 992 & N.S. \\
\hline ERROR, E & 2 & 11.1667 & 5.58333 & & & & \\
\hline TOTAL & 11 & 410.16667 & & & & & \\
\hline
\end{tabular}

TABLE II. SUMMARY OF ANALYSIS OF VARIANCE-ANGLE OF INTERNAL FRICTION.

\begin{tabular}{|c|c|c|c|c|c|c|c|}
\hline $\begin{array}{l}\text { SOURCE OF } \\
\text { VARIATION }\end{array}$ & $\begin{array}{l}\text { DEGREES } \\
\text { OF } \\
\text { FREEDOM }\end{array}$ & $\begin{array}{l}\text { SUM OF } \\
\text { SOUARES }\end{array}$ & $\begin{array}{l}\text { MEAN } \\
\text { SQUARE }\end{array}$ & $\mathrm{F}$ & $\mathrm{F} .05$ & $F_{.10}$ & $\begin{array}{l}\text { SIGNI- } \\
\text { FICANCE }\end{array}$ \\
\hline $\begin{array}{l}\text { AGGREGATE TYPE } \\
\text { (STONE VS GRAVEL), A }\end{array}$ & 1 & 22680.90750 & 22680.90750 & 1037169 & 185 & 8.53 & $F_{.05}$ \\
\hline $\begin{array}{l}\text { PERCENT PASSING } \\
\text { NO. } 200 \text { SIEVE, C }\end{array}$ & 1 & 626.40750 & 626.40750 . & 28645 & 18.5 & 8.53 & N.S \\
\hline $\begin{array}{l}\text { PERCENT RETAINED } \\
\text { BETWEEN NO } 30 \text { AND } \\
\text { NO. } 200 \text { SIEVES, D }\end{array}$ & 2 & 68.32167 & 3416083 & .1562 & 190 & 9.92 & N S \\
\hline $\begin{array}{l}\text { INTERACTIONS } \\
A \times C\end{array}$ & 1 & 910.02083 & 910.02083 & 4.1614 & 18.5 & 8.53 & NS \\
\hline$A \times 0$ & 2 & 4097.37500 & 2048.68750 & 9.3684 & 19.0 & 992 & NS \\
\hline$C \times D$ & 2 & 16276550 & 813.82750 & 37215 & 190 & 992 & N.S \\
\hline ERROR, E & 2 & 43736167 & 21868083 & & & & \\
\hline TOTAL & 11 & 30448.04917 & & & & & \\
\hline
\end{tabular}


All main effects and interactions not significant at the 25 percent level were pooled. Using $F_{(2,2 ; .25)}=3.00$ and $F_{(1,2 ; .25)}=2.57$ and comparing with computed F-values as shown in Table 10, these effects were compriaed of the main effect $D_{1}$ and the interaction $\mathrm{CD}_{k 1}$. This resulted in an error term $E^{\prime *}$ with 8 n $\mathrm{MSE}^{\prime}=8.25$ and d. $\mathrm{F}_{0}=6$. Now:

Main effect $A:$ d.f. $=1 ; F_{A}=\frac{M S A}{M S E}=\frac{216.75}{8.25}=26.27$, Main effect $C:$ d. $f_{0}=1 ; F_{C}=\frac{M S C}{M S E}=\frac{56.33}{8.25}=6.82$, Interaction $A \times C: d . f_{0}=1 ; F_{A C}=\frac{M S(A D)}{M S E}=\frac{24.08}{8.25}=2.92$, Interaction $A \times D: d . E_{0}=2 ; F_{A D}=\frac{M S(A D)}{M S E}=\frac{31.75}{8.25}=3.85$. Comparing these computed F-values with the statistics $F_{(1,6 ; .05)}=5.99$ and $F_{(2,6 ; .05)}=5.14$, only the main effects $A$ and $C$ are significant at the five percent signiflcant level. That is, only aggregate type and percent passing the No. 200 steve had any significant effect on triaxial compresalve strength. Therefore, the model given by equation 15 is modified to:

$$
Y_{i k 1}^{\prime}=v+A_{i}+C_{k}+E_{(1 k 1)}
$$

Table 11 gives a sumary of the analysis of varlance of the angle of Internal friction data. Equation 13 gives the assumed model of

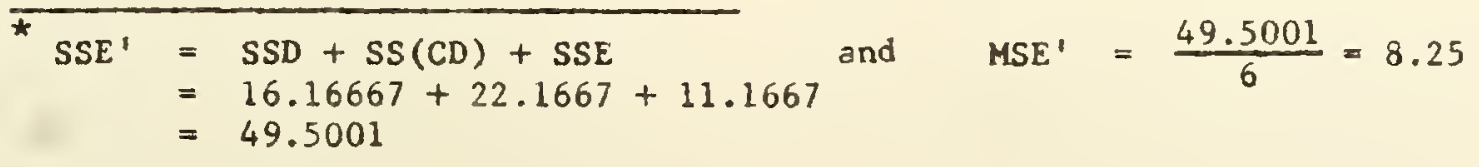


analysis of varlance for this case. The results of the F-test at the five percent significant level indicate that only the effect of aggregete type tested significant. This reduces equation 13 to:

$$
Y^{\prime \prime}{ }_{i k 1}=U+A_{i}+E_{(i k l)}
$$

Also, on testing at the 25 percent significant level, the effect $D_{1}$ did not show signiffcance. On pooling this effect with the error term $E$, the pooled ertor term $E^{\prime}$ had an $M S E^{\prime}=126.42$ with d.f. $=4$. Using the new errol teim, it was determined that besides the effect of aggregate type, the etfect of interaction of aggregate type and the percent retained belween the No. 30 and No. 200 sieves was also significant at the five percent level. Hence, equation 17 is replaced by :

$$
Y_{i k 1}^{\prime \prime}=U+A_{1}+A D_{k l}+E_{(i k 1)}
$$

This would be the model that would govern the variation in angle of internal friction data.

Table 12 shows the Texas triaxial test data layout for analyges of variance governed by the assumed models given in equations 12 and 14. Table 13 sumarizes the results of analysis of variance of the tilaxial compressive strength data. Equation 12 glves the assumed analysis of variance model for this case. The results of the anelysis indicate that the effect of the interaction of percent material passing the No. 200 sieve and the percent material retalned between the No. 30 and No. 200 aieves was significant at the ten percent level. The effect $B^{\prime} C_{j k}$, not significant at the 25 percent level and the error term $E$, were pooled and the remaining effects were tested against the new error term $E^{\prime}$ for significance. The pooled error 
TABLE 12. SUMMARY OF TEXAS TRIAXIAL TEST DATA.

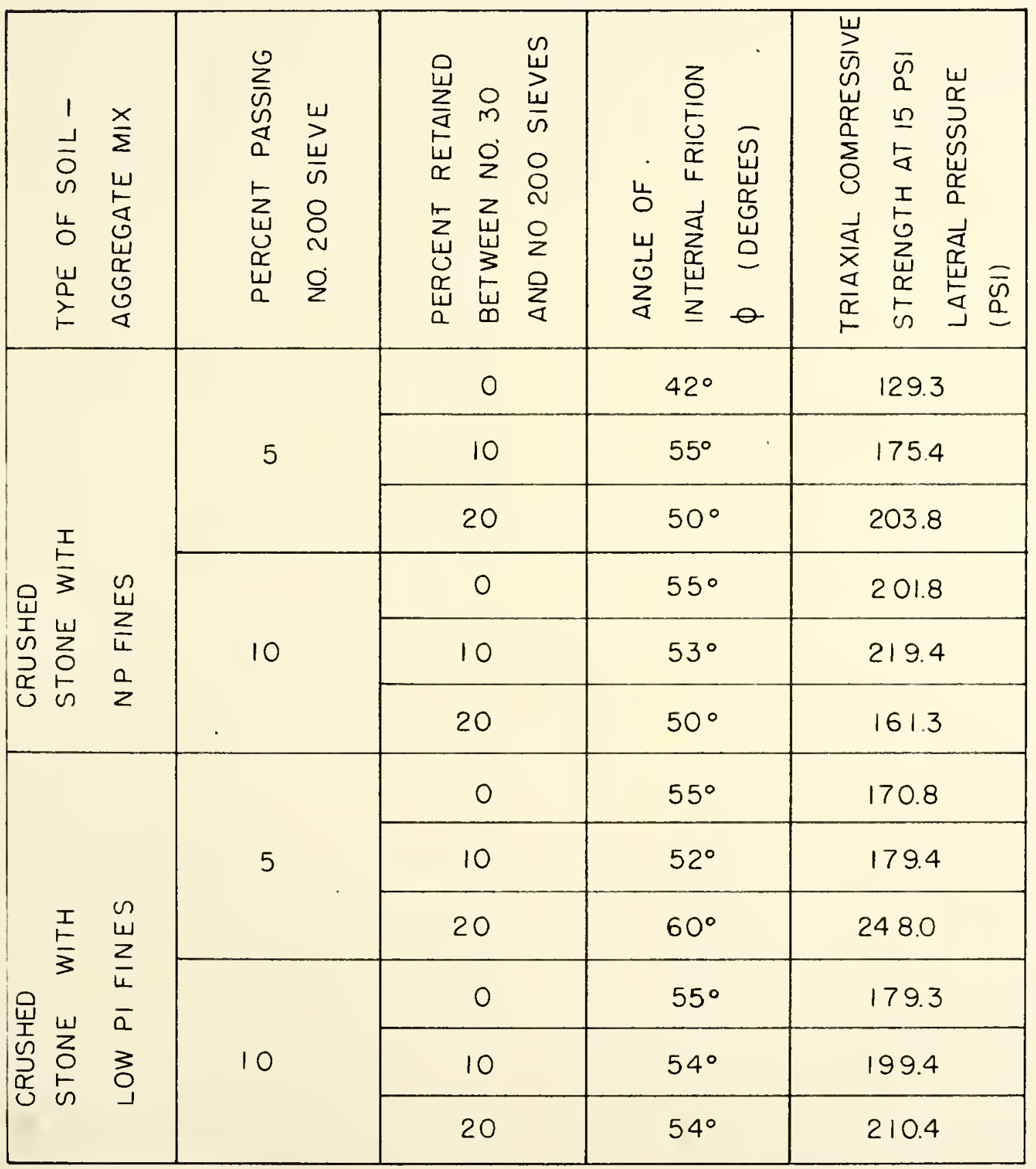


TABLE 13. SUMMARY OF ANALYSIS OF VARIANCE -TRIAXIAL COMPRESSIVE STRENGTH AT 15 PSI LATERAL PRESSURE.

\begin{tabular}{|c|c|c|c|c|c|c|c|}
\hline $\begin{array}{l}\text { SOURCE OF } \\
\text { VARIATION }\end{array}$ & $\begin{array}{c}\text { DEGREES } \\
\text { OF } \\
\text { FREEOOM }\end{array}$ & $\begin{array}{l}\text { SUM OF } \\
\text { SOUARES }\end{array}$ & $\begin{array}{l}\text { MEAN } \\
\text { SOUARE }\end{array}$ & $F$ & $F_{.05}$ & $F_{10}$ & $\begin{array}{l}\text { SIGNI- } \\
\text { FICANCE }\end{array}$ \\
\hline $\begin{array}{l}\text { PLASTICITY OF } \\
\text { FINES, }\end{array}$ & 1 & 1089.27907 & 1089.27907 & 6.6891 & 18.5 & 853 & N.S. \\
\hline $\begin{array}{l}\text { PERCENT PASSING } \\
\text { NO. } 200 \text { SIEVE, }\end{array}$ & 1 & 573.11541 & 573.11541 & 35194 & 18.5 & 8.53 & N.S. \\
\hline $\begin{array}{l}\text { PERCENT RETAINED } \\
\text { BETWEEN NO } 30 \text { AND } \\
\text { NO. } 200 \text { SIEVES, D }\end{array}$ & 2 & 1952.594471 & 976.29723 & 5.9953 & 19.0 & 9.92 & NS. \\
\hline $\begin{array}{c}\text { INTERACTIONS } \\
B^{\prime} \times C\end{array}$ & 1 & 353.49308 & 353.49308 & 2.1708 & 18.5 & 8.53 & N.S. \\
\hline $8^{\prime} \times 0$ & 2 & 1495.45580 & 747.72790 & 45917 & 19.0 & 992 & N.S. \\
\hline$C \times D$ & 2 & 4506.29470 & 2253.14703 & 138363 & 19.0 & 9.92 & $F_{.10}$ \\
\hline ERROR, E & 2 & 325.68540 & 16284270 & & & & \\
\hline TOTAL & 11 & 10295.91729 & & & & & \\
\hline
\end{tabular}

TABLE 14. SUMMARY OF ANALYSIS OF VARIANCE-ANGLE OF INTERNAL FRICTION.

\begin{tabular}{|c|c|c|c|c|c|c|c|}
\hline $\begin{array}{l}\text { SOURCE OF } \\
\text { VARIATION }\end{array}$ & $\begin{array}{l}\text { DEGREES } \\
\text { OF } \\
\text { FREEDOM }\end{array}$ & $\begin{array}{l}\text { SUM DF } \\
\text { SQUARES }\end{array}$ & $\begin{array}{l}\text { MEAN } \\
\text { SOUARE }\end{array}$ & $F$ & $F_{05}$ & $F_{10}$ & $\begin{array}{l}\text { SIGNI- } \\
\text { FICANCE }\end{array}$ \\
\hline $\begin{array}{l}\text { PLASTICITY OF } \\
\text { FINES, }\end{array}$ & 1 & 50.02083 & 5002083 & 25956 & 18.5 & 8.53 & N.S. \\
\hline $\begin{array}{l}\text { PERCENT PASSING } \\
\text { NO. } 200 \text { SIEVE, C }\end{array}$ & 1 & 3.52083 & 352083 & 1827 & 185 & 8.53 & NS \\
\hline $\begin{array}{l}\text { PERCENT RETAINED } \\
\text { BETWEEN NO.3O AND } \\
\text { NO ZOO SIEVES, D }\end{array}$ & 2 & 9.37500 & 4. 68750 & 2432 & 19.0 & 9.92 & N.S. \\
\hline $\begin{array}{l}\text { INTERACTIONS } \\
8^{\prime} \times C\end{array}$ & 1 & 20.02083 & 20.02083 & 1.0389 & 18.5 & 8.53 & NS \\
\hline$B^{\prime} \times 0$ & 2 & 39.04167 & 19.52083 & 1.0129 & 19.0 & 992 & N.S. \\
\hline$C \times D$ & 2 & 4454167 & 22.27083 & 1.1557 & 19.0 & 9.92 & N.S. \\
\hline ERROR, E & 2 & 38.54167 & 19.27083 & & & & \\
\hline TOTAL & 11 & 205.06250 & & & & & \\
\hline
\end{tabular}


term $E^{\prime}$ had $\mathrm{MSE}^{\prime}=226.39$ and $\mathrm{d}_{\mathrm{f}_{\mathrm{f}}=3}=3$. On testing at a five percent signiflcant level and using the pooled error term, only the interaction between the percent passing the No. 200 sieve and the percent retained between the No. 30 and No. 200 sieves tested significant. Hence, equation 12 reduces to:

$$
Y_{j k l}^{\prime}=U+C D_{k l}+E_{(j k 1)}
$$

Table 14 gives a summary of the analysis of varlance of the angle of internal friction data. The governing model for this analysis $1 \mathrm{~s}$ given by equation 14 . On examining the F-test results, no effect or Interaction was significant. Even on pooling the effects not significant at the 25 percent level and using the pooled error term as an estimate of the true error effect, the result still remained the same, 1.e., no main effect or interaction was significant. Therefore, equation 14 becomes:

$$
Y_{j k l}^{\prime \prime}=U+E_{j k l}
$$

Before deducing any conclusions, one aspect of the above analysis of variance must be kept in mind. Á pure error term was not considered. It was confounded by the three-factor interaction. This makes the analysis less robust and to a degree less rellable. No analysis is better than the data on which it is based. Oring to lack of replicates, the results of the above analyses might have been based on a false premise. Hence, the conclusions derived from this analyses should be viewed with caution. 
The analysis of Texas triaxial test data may be summed up as:

1. In case of soll-gravel vs. soll-crushed stone mixes, only the aggregate type and the percent fines had a algalficant effect on trlaxial compressive strength. However, the varlation in angle of internal friction was influenced not only by the aggregate type but also by the interaction of the aggregate type with the percent retained between No. 30 and No. 200 steves.

2. In case of soll-crushed stone mixes with NP flnes vs. sollcrushed stone mixes with low PI fines, the variation in triaxtal compressive strength was explained by the interaction of percent fines with percent retalned between the No. 30 and No. 200 sleves. This shows that dust ratio had an Important influence on trlaxlal compressive strength. The variation in angle of Internal friction data was mainly a result of experimental error. 


\section{INTERPRETATION OF RESULTS}

The deduction of results required the study of the effect of the fraction retained between the No. 30 and No. 200 sieves on CBR, triaxial compressive strength, compactive dengity, plasticity, and permeability characteristics of the soll-aggregate test mixtures. The foregoing atatistical analysis provided the guidelines for evaluating the results.

\section{CBR Tests}

For this study, a soil-aggregate test mixture testing at a CBR of 80 percent or above was considered to be a good base matertal relative to strength characteristics. Flgures 6 and 7 show the variation of CBR with percent retained between the No. 30 and No. 200 sieves. In these lllustrations, graphs were fitted only to the data of the mixtures that tested significant in the one-way analysis of variance. * The curves were plotted using a regression analysis as a means of fitting the curves. A sumary of the results of the regression analysis is given in Table B-1. The discussion that follows applies to the CBR results obtained using the 56-blow compaction as required in the standard test procedure.

The effect of percent retained between No. 30 and No. 200 sieves makes a significant contribution to the varlation of CBR test results at the .05 level of significance. 
NUMBERS IN PARENTHESES ARE

PI VALUES
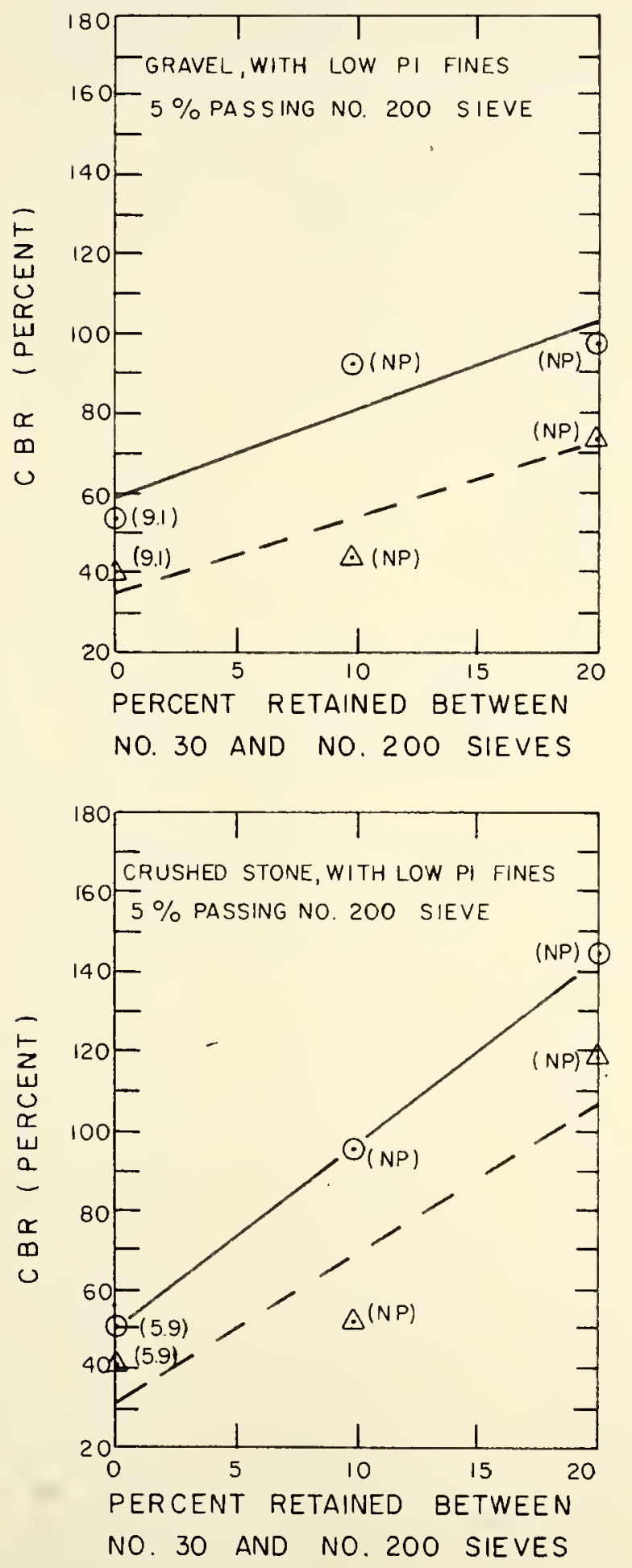

FIG.6. VARIATION OF CALIFORNIA RETAINED BETWEEN NO. 30 (CBR VALUES ARE THE AVERAGE OF TWO TESTS)

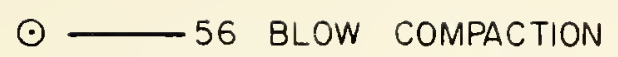

$\triangle---28$ BLOW COMPACTION
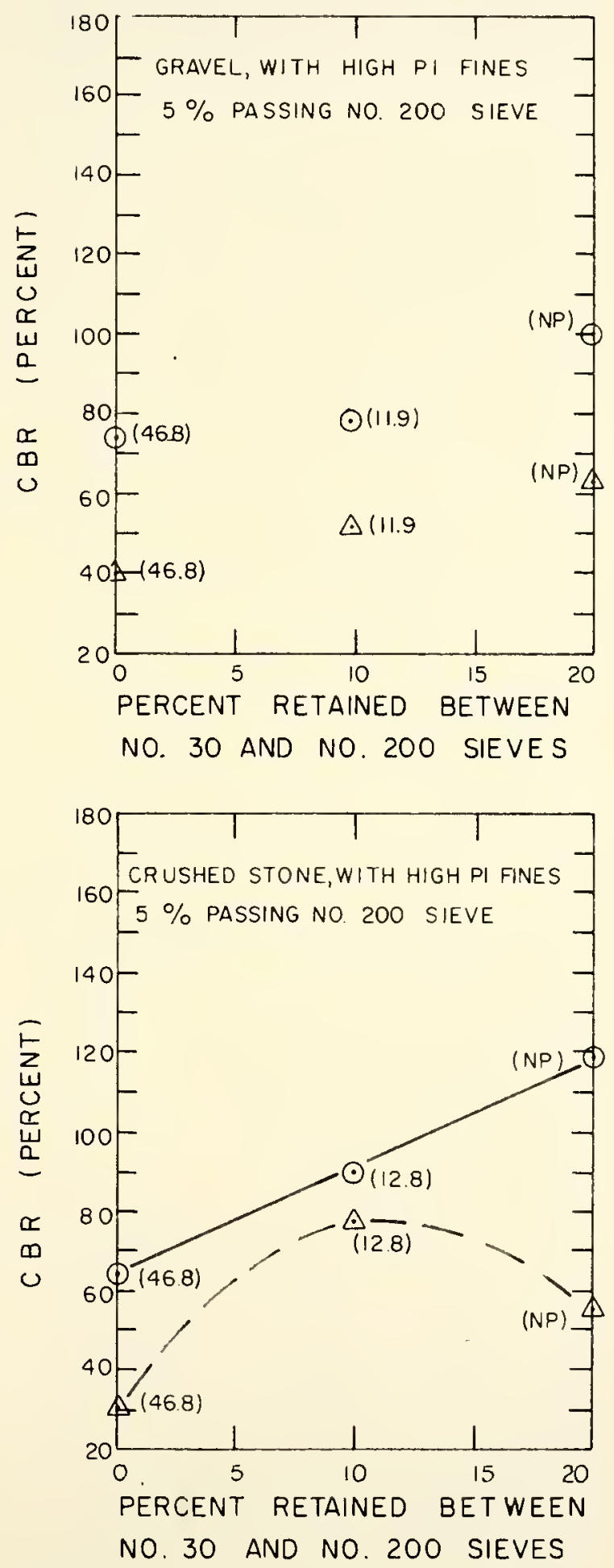

BEARING RATIO WITH PERCENT AND NO. 200 SIEVES. 

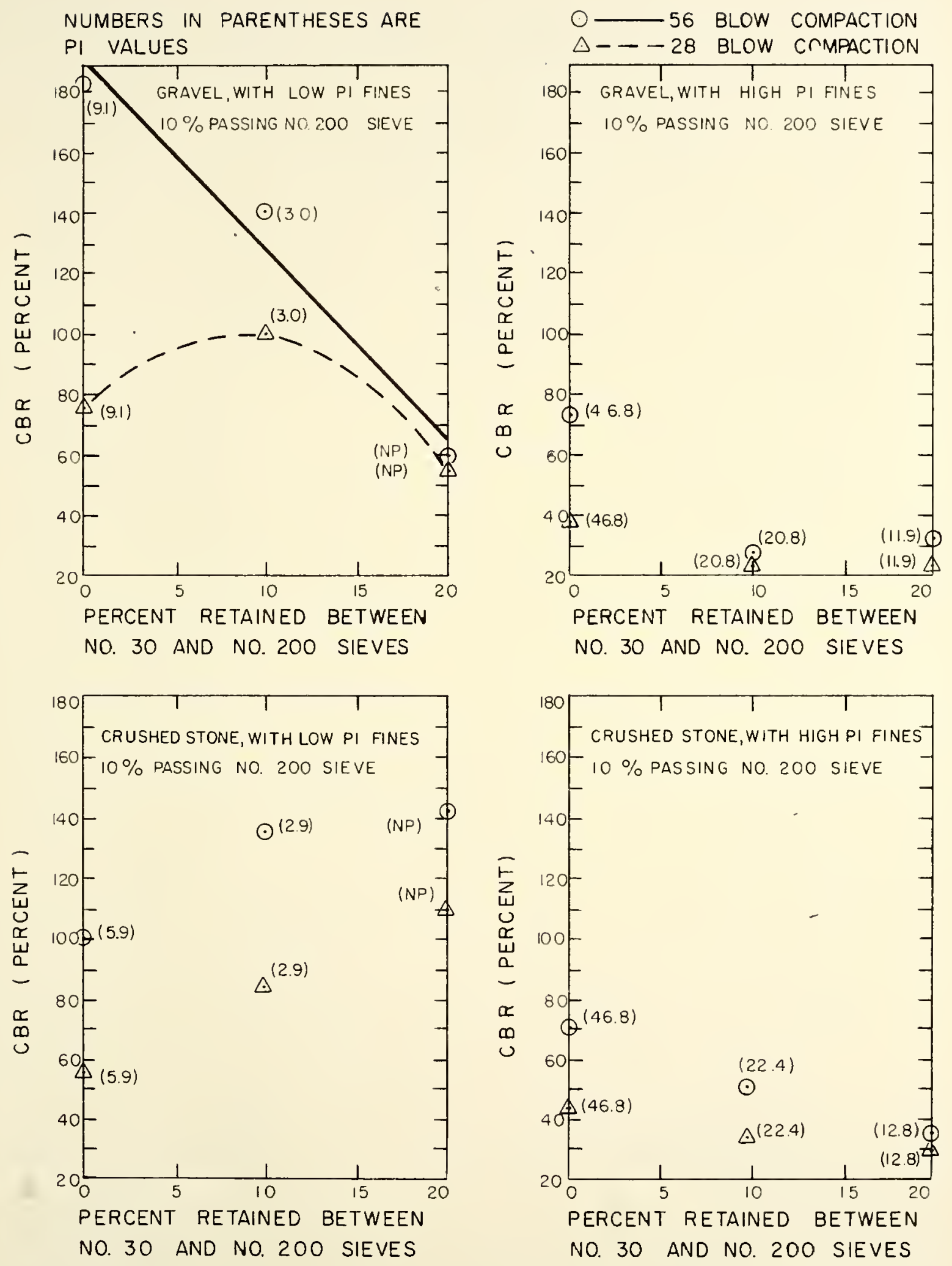

FIG.7. VARIATION OF CALIFORNIA BEARING RATIO WITH PERCENT

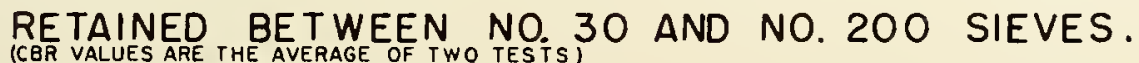


Figure 6 applies to mixes with five percent fines (material passing the No. 200 sieve). As the fraction retalned between the No. 30 and No. 200 sieves was decreased, the gravel and crushed stone mixes with low plasticity fines suffered a decrease in CBR. This was also true for the crushed stone mixes with high plasticity fines. The variation in CBR of the gravel mixes with high plasticity fines was not influenced by the amount of material between the No. 30 and No. 200 sieves. For the completely sklp-graded mixes, i.e., without any materlal retained between the No. 30 and No. 200 sleves, the CBR values were appreciably lower than those for we 11 -graded mixes. This instability resulted from a relative lack of soll matrix in these mixes. * The physical state of these mixes corresponds to condition (a) in Figure 1.

The variation of CBR with percent retained between the No. 30 and No. 200 sieves, for mixes with ten percent fines, is shown in Figure 7. The varlation in the strength of crushed stone mixes, irrespective of the type of fines, was not dependent on the amount of material retained between the No. 30 and No. 200 sleves. This was also true for the gravel mixes with high plasticity flnes. However, this fraction had an important influence on the strength of gravel mixes with low plasticity fines. It can be observed that there was a substantial increase in the CBR of these mixes as the fraction between the No. 30 and No. 200 mesh sleves was

In this study, soll is defined as the material pasing the No. 30 sieve. 
decreased. For the extreme case, where all material between the No. 30 and No. 200 sieves was removed, an average CBR of 184 percent was recorded.

Using a CBR of 80 percent as the strength criterion for an adequate base, the data indicate that:

1. For gravel mixes with five percent fines, irrespective of the plasticity of fines, the percent retained between the No. 30 and No. 200 sieves should be about ten percent or greater.

2. For crushed stone mixes with five percent fines, irrespective of the plasticity of fines, the percent retained between the No. 30 and No. 200 sieves should remain above six percent.

3. With only live percent fines in the mix, complete skipgrading of the fraction between the No. 30 and No. 200 mesh siever was harmful to the CBR characteristics of both gravel and crushed stone mixes.

4. For gravel mixes with ten percent low plasticity fines, the percent retained between the No. 30 and No. 200 sieves should remain below 17 percent.

5. All crushed stone mixes with ten percent low plasticity fines showed adequate CBR irrespective of the amount of material between the No. 30 and No. 200 sieves.

6. The crushed stone and gravel mixes with ten percent high plasticity fines did not meet the minimum strength criterion 
for sdequate CBR, irrespective of the amount of materlal retained between the No. 30 and No. 200 sieves.

7. With ten percent fines, skip-grading of this fraction was not harmful' to the CBR of either the gravel mixes or the crushed stone mixes with low PI fines. In fact, an increase in CBR resulted for the gravel mixes. Gravel and crushed stone mixes with high PI fines showed strength values below the stipulated criterion for all cases under investigation. The above brings to light a very important characteristic. It appears that there is a strong interplay between the percent fines and the soil fraction between the No. 30 and No. 200 sleves in their effect on CBR characteristics of soil-aggregate mixes. This substantiates a gimilar deduction obtained from the statistical analysis.

To investigate this characteristic further, the variation of CBR with dust ratio was studied. A dust ratio of 1.00 signifles a completely skip-graded mix. Examination of Tables 15 and 16 shows that in case of crushed stone and gravel mixes with five percent fines, an tncrease in the dust-ratio from 0.20 to 1.00 caused a decrease in CBR values. Gravel mixes, with ten percent low plasticity fines, showed a substantial increase in $C B R$ with increase in dust ratio from 0.30 to 1.00 . In essence, this was also true for crushed stone and gravel mixes with high plasticity fines. The trend did not hold for crushed stone mixes with low plasticity fines.

Using an 80 percent $C B R$ to signify an adequate hase material, Figures 6 and 7 suggest that: 
光

ज $\dot{n}$

ণᄄ 心

世

으응

我

$-4$

en

ว

I点

으늠

近

$\widetilde{q}$

0

$\frac{z}{\sigma}$

峞

剀

$\varangle \frac{1}{4}$

$\sum_{\sim}$

으엉

志岕 岕

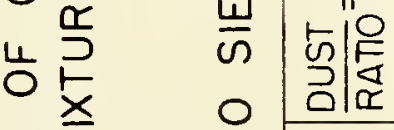

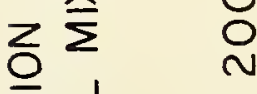

岕崖焉
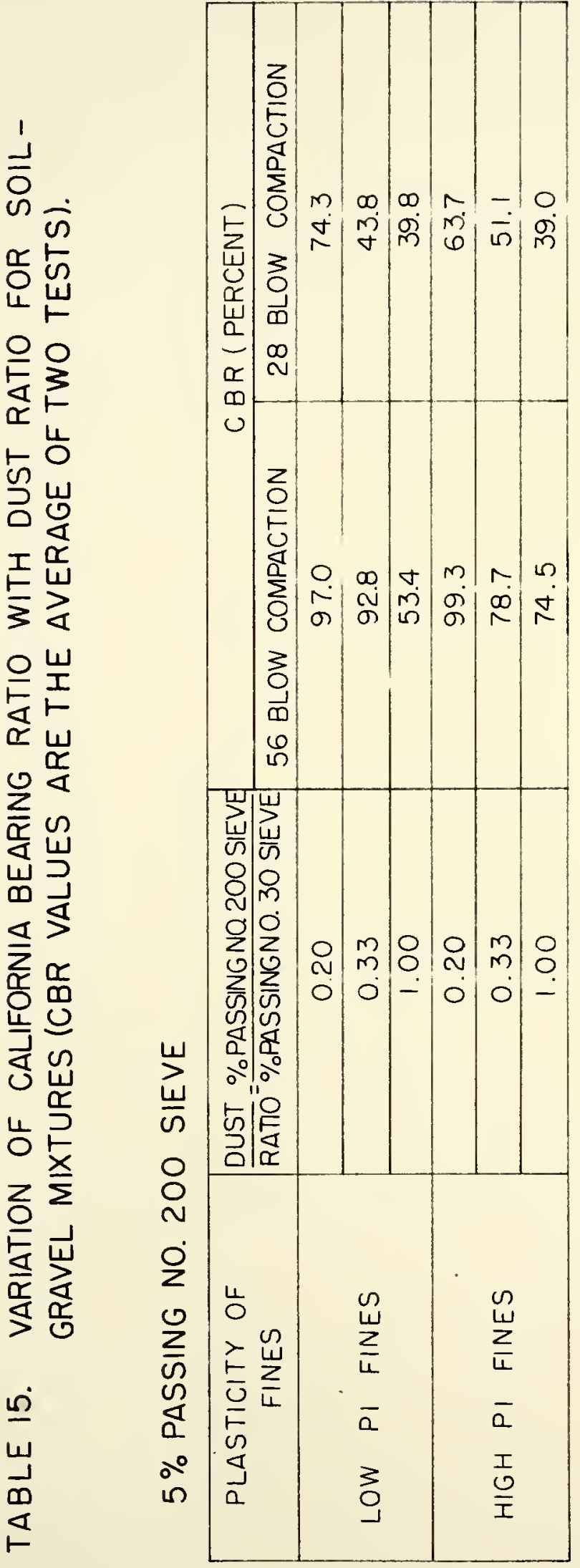

३े

in

एफ

$\bar{\omega}$

8요

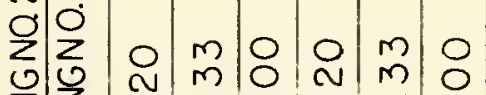

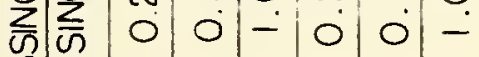

高年

20

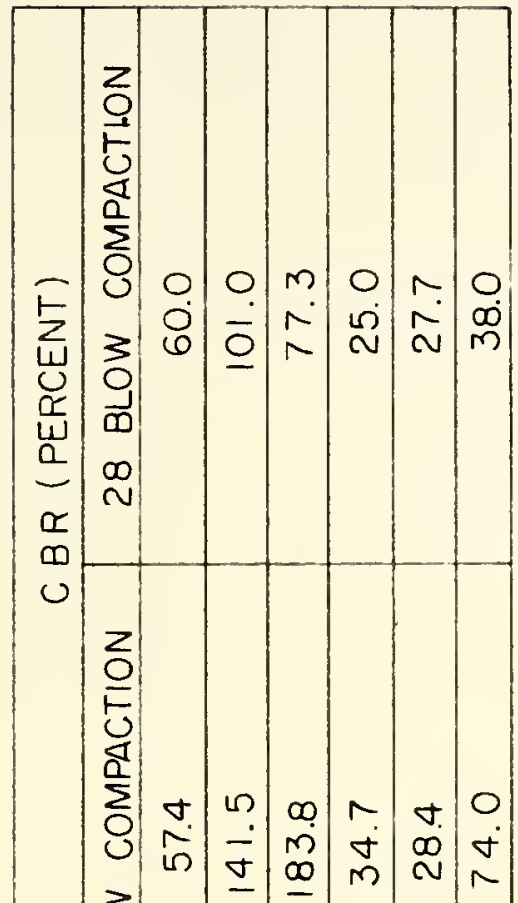

齐

官

岁岁

领岕

8 응

穴运

就

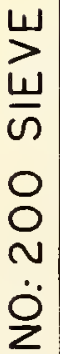

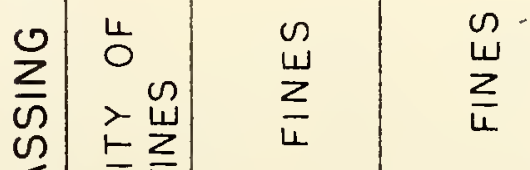

造

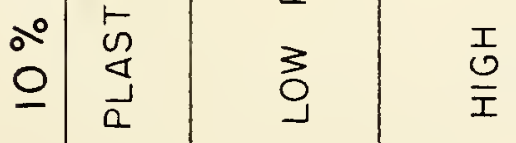




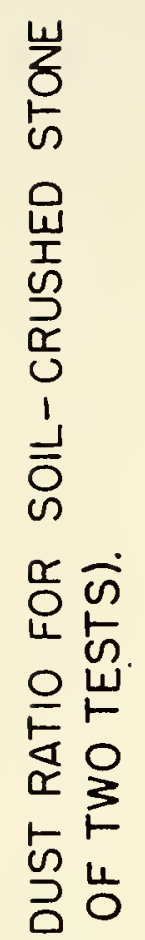

퍼엉

는

u

岗 崩

嵒

步

$\frac{1}{3}>$

$\frac{a}{\infty}$

임

zN

은 崖定

$\stackrel{\frac{\alpha}{x}}{\frac{x}{\Sigma}}$

$\underline{\varphi}$

w

m

8

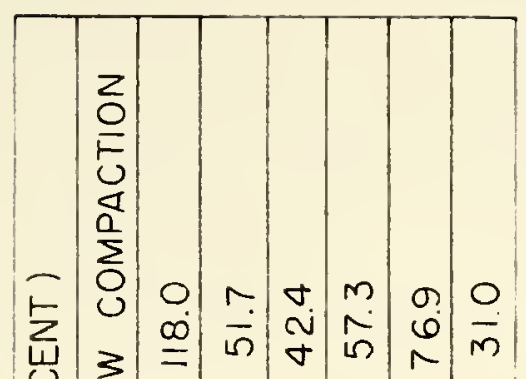

䌢

문

a

u

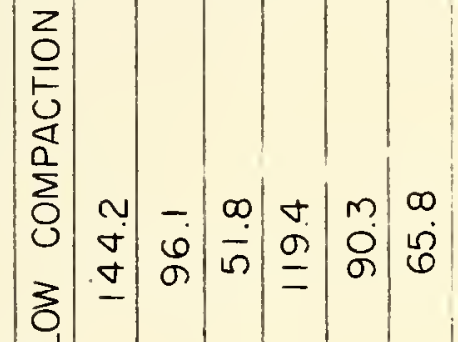

ब.

เก

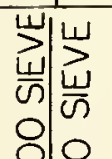

위요

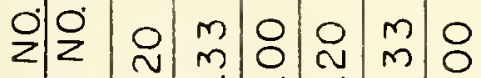
뉘는

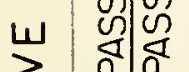

ш $\frac{1}{\circ} \frac{a}{\circ}$

ต

기조

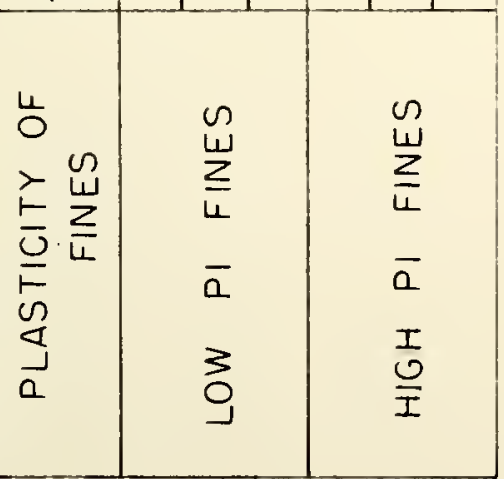

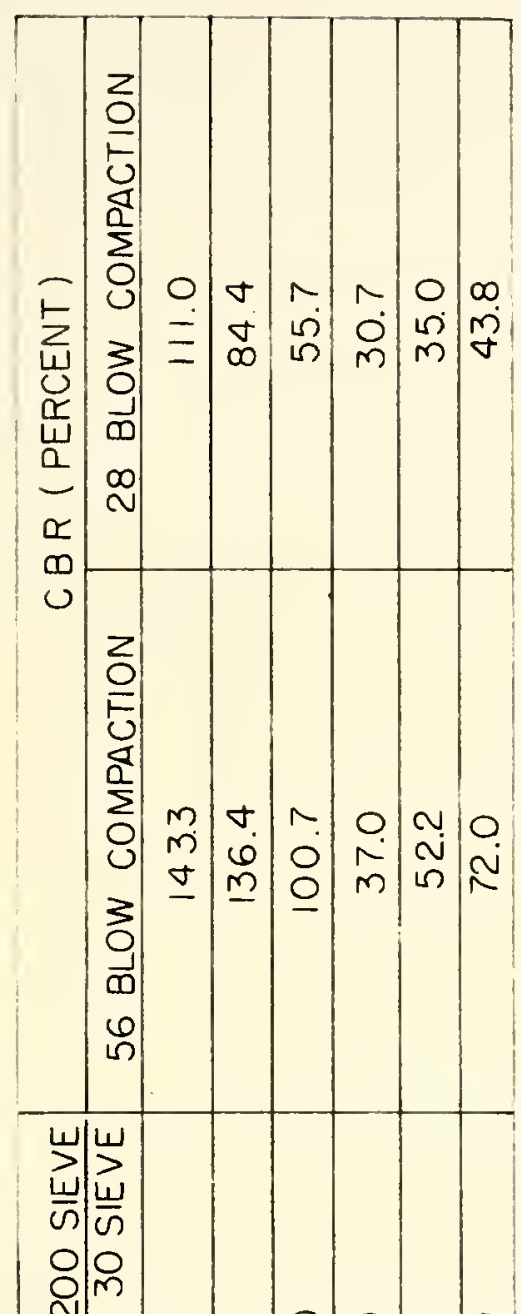

일 $\begin{array}{llllllllll}0 & 0 & 0 & - & 0 & 0 & -\end{array}$

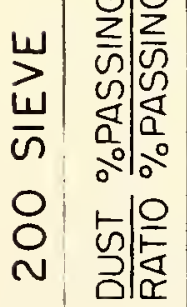

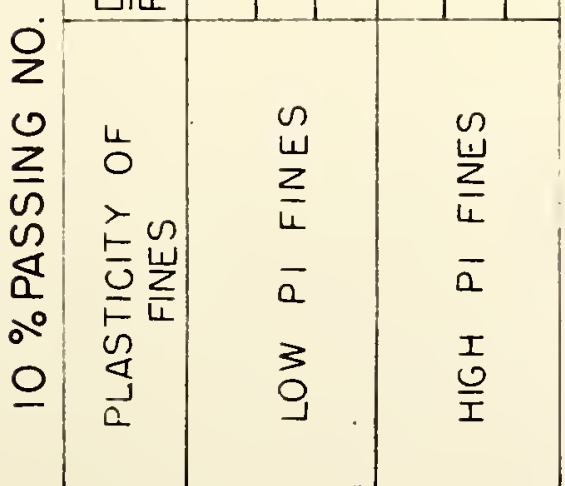


1. For a gravel mix with five percent low plasticity fines, the dust ratio should not be greater than $\frac{5}{5+10}=0.33$.

2. For crushed stone mixes with five percent fines and irrespective of the plasticity of fines, dust ratio should not be greater than $\frac{5}{5+6}=0.45$. This is also true for gravel mixes with high plasticity fines.

3. For gravel mixes with ten percent low PI fines, dust ratio should not be less than $\frac{10}{10+17}=0.37$.

4. Dust ratio had no influence on $C B R$ characteristics of crushed stone mixes with ten percent low plasticity fines.

5. Gravel and crushed stone mixes with ten percent high plasticity fines were not arfected by dust ratio as the CBR of these mixes were below the governing criterion for an adequate base.

The effect of variable compaction on CBR test results $1 \mathrm{~s}$ shown in Figures 6 and 7. There was no significant effect other than lower CBR values for 28-blow compaction as compared to mixes subjected to 56-blow compaction. With two exceptions, the trends regarding the effect of skip-grading on CBR remained basically the same as demonstrated by mixes subjected to 56-blow compaction. Gravel mixes with ten percent low plasticity flneg showed higher $C B R$ values when the percent retained between the No. 30 and No. 200 sleves was constrained to about eight percent. Crushed stone mixes with five percent high plasticity fines dewonstrated a similar characteristic. Th1s means that these soll-aggregate mixes, when subjected to a relotively lower compaction indicated an optimum 
value for the percent material retained between the No. 30 and No. 200 sleves. A decrease below or increase above this value reaulted in lower CBR values. This deviation from establiahed trends can be explained by the fact that a decrease in compactive effort does not result in an equal decrease in compactive denaities for all types of so1l-aggregate mixes. A study of Table A-2 would indicate that a 50 percent decrease in compactive effort (28-blow compaction vs. 56-blow compaction) caused a decresse in compactive density anywhere from 93 percent to 99 percent for the soil-aggregate mixes under study.

\section{Texas Triaxial Tests}

The criterion used in evaluating test results required that an adequate base course material exhibit a triaxial compressive strength of 175 psi at a confining pressure of 15 psi. It was further required that the angle of internal friction, as measured from Mohr's envelope, should not be less than $50^{\circ}$.

The variation of triaxial compressive strength and angle of Internal friction with the fraction retained between the No. 30 and No. 200 sieves is shown in Tables 17 and 18. The following reaulta apply to mixes with five percent fines. (Refer to Tables 17 and A-3.)

1. Gravel mixes with low plasticity fines indicated the highest compressive strength and internal friction when the percent retained between the No. 30 and No. 200 sieves was confined to approximately ten percent and the dust ratio was about 0.33 . 

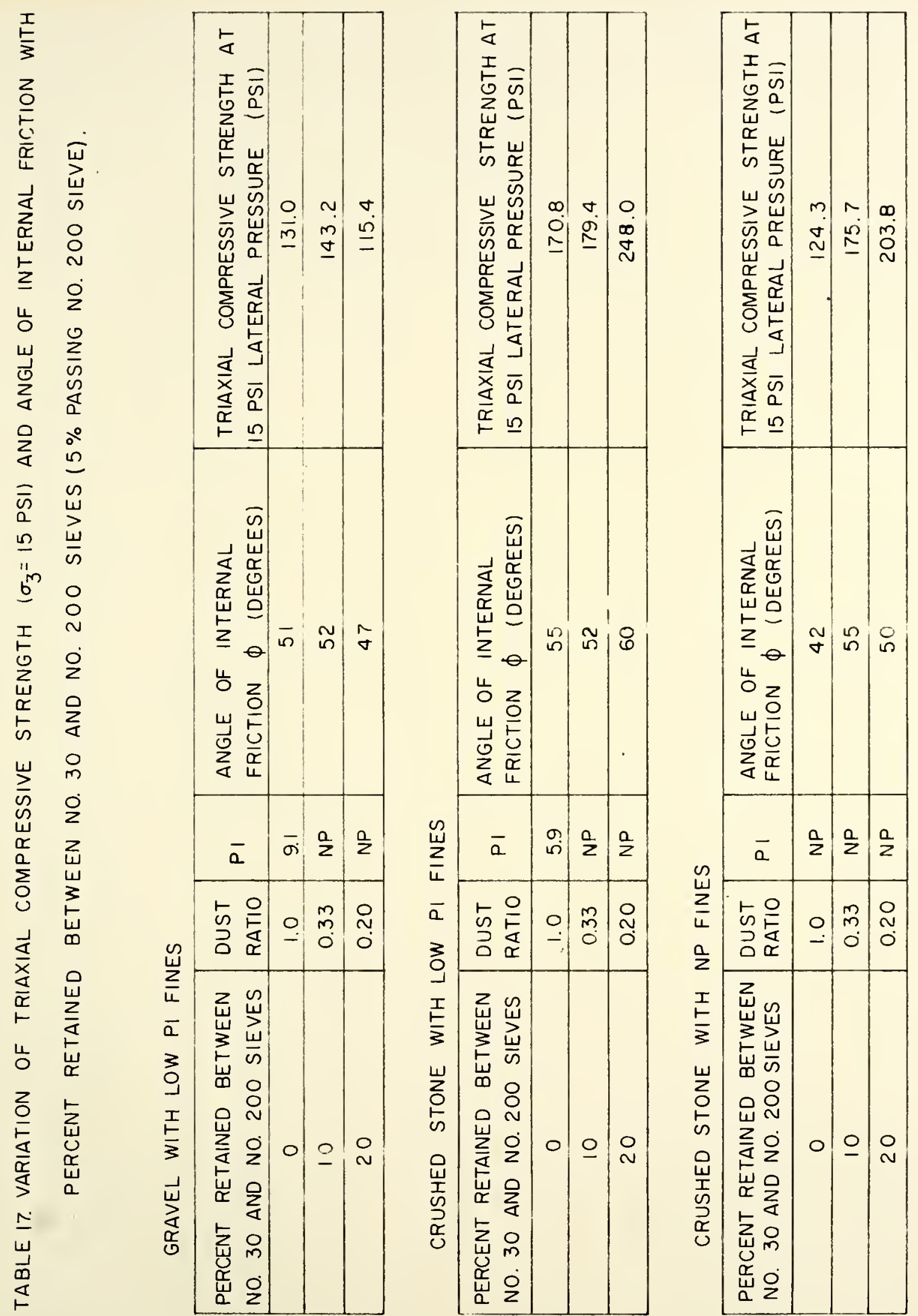


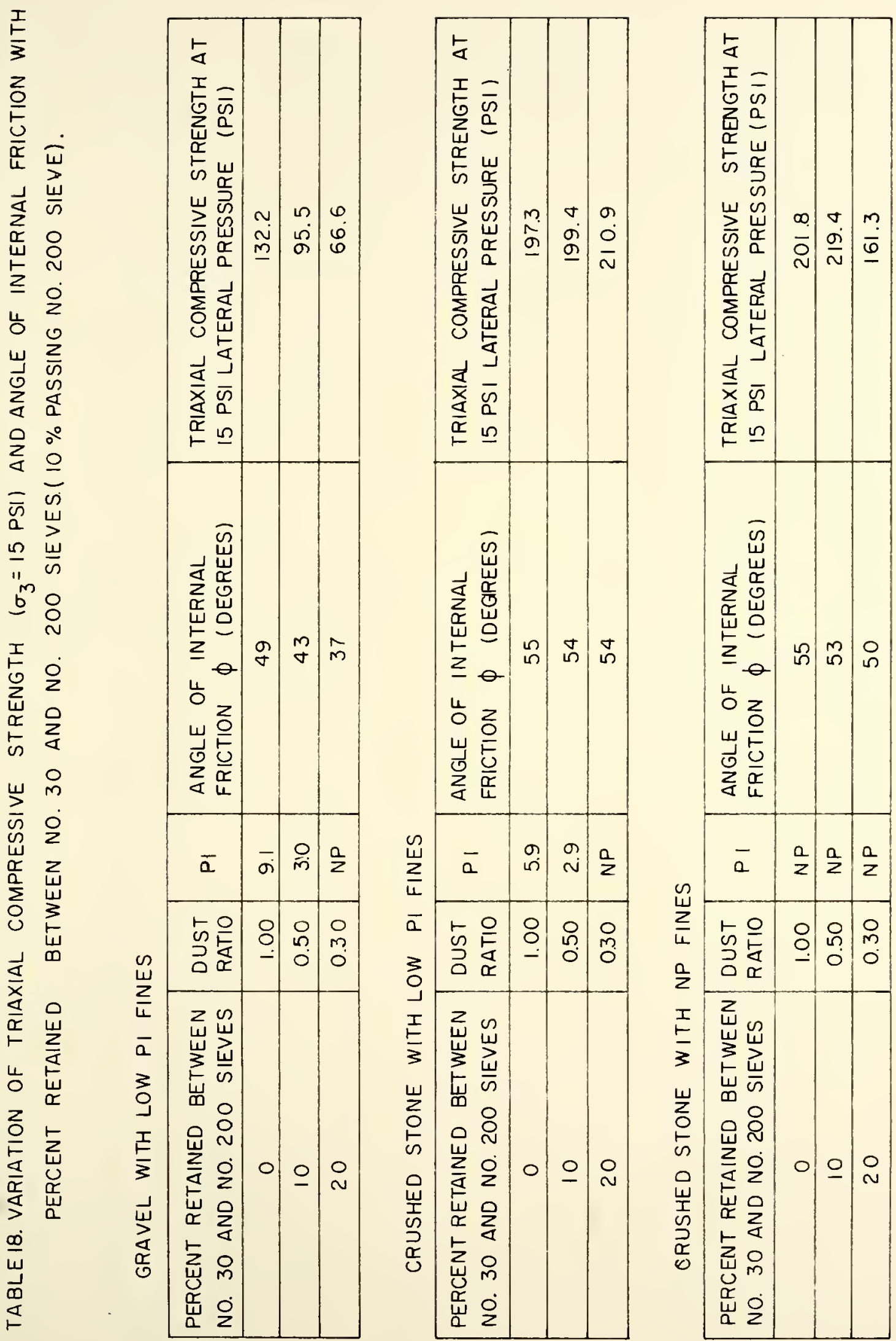


2. Crushed stone mixes with both non-plastic and low PI fines showed an increase in triaxial compressive strength and angle of internal friction with an incresse in percent retained between the No. 30 and No. 200 sieves. For these mixes, dust ratio should remain below 0.33 .

3. Crushed stone mixes tested at a higher Texas triaxial clsos than gravel mixes.

4. Crushed stone mixes with low plasticity fines showed strength characteristics comparable to crushed stone mixes with nonplastic finer.

The results indicated below apply to mixes with ten peicent fines. (Refer to Tables 18 and $A-3$. )

1. In case of gravel mixes with low plasticity fines, triaxial compresaive strength and angle of internal friction decreased with increase in the fraction retalned between the No. 30 and No. 200 sieves. For the extreme case, with a dust ratio of 1.0 , highest values of compressive strength and internal friction were obtained.

2. The variation in triaxial compressive strength and the angle of internal friction was not influenced by the amount of material between the No. 30 and No. 200 sieves, in case of crushed stone mixes with low PI fines. The change in stability parameters was very small with variation in the fraction between the No. 30 and No. 200 sieves.

3. Crushed stone mixes with non-plastic fines indicated that better strength results were obtained as the material 
between the No. 30 and No. 200 sleves was decreased.

4. Crushed stone mixes tested at a higher triaxtal class than gravel mixes.

5. There was no distinct differences in the strength properties of crushed stone mixes with low plastictey fines as opposed to the ones with non-plaste fines.

In general, the trlaxial compresstve strength results showed the same trends as CBR test results. The high CBR values indicated for soll-gravel mixes were not corroborated by Texas triaxial test results. Invariably, the soil-gravel mixes tested st a lower Texas triaxial class as compared with soll-crushed stone mixes with similar gradation characteristics.

The critical values of dust rat:o for varlous soil-aggregate mixes, as determined by the CBR tect results, compared well with the values obtained from an analysis of Texas trlaxial test results. Crushed stone mixes with low plasticlty fines gave approximately the same strength values as crushed stone mixes with non-plastlc fines.

\section{Permeabilicy Tests}

Typical permeabllity values for solls (14) are glven in Table 19. The permeability test results are graphically 11lustrated in Figure 8. An analysis of these results shows that: (a) permeability decreases with increased amounts of material between the No. 30 and No. 200 sieves; (b) mixes with five percent fines had higher permeability than mixes with ten percent fines; (c) the effect of material retalned between the No, 30 and No. 200 sleves on permeability was 


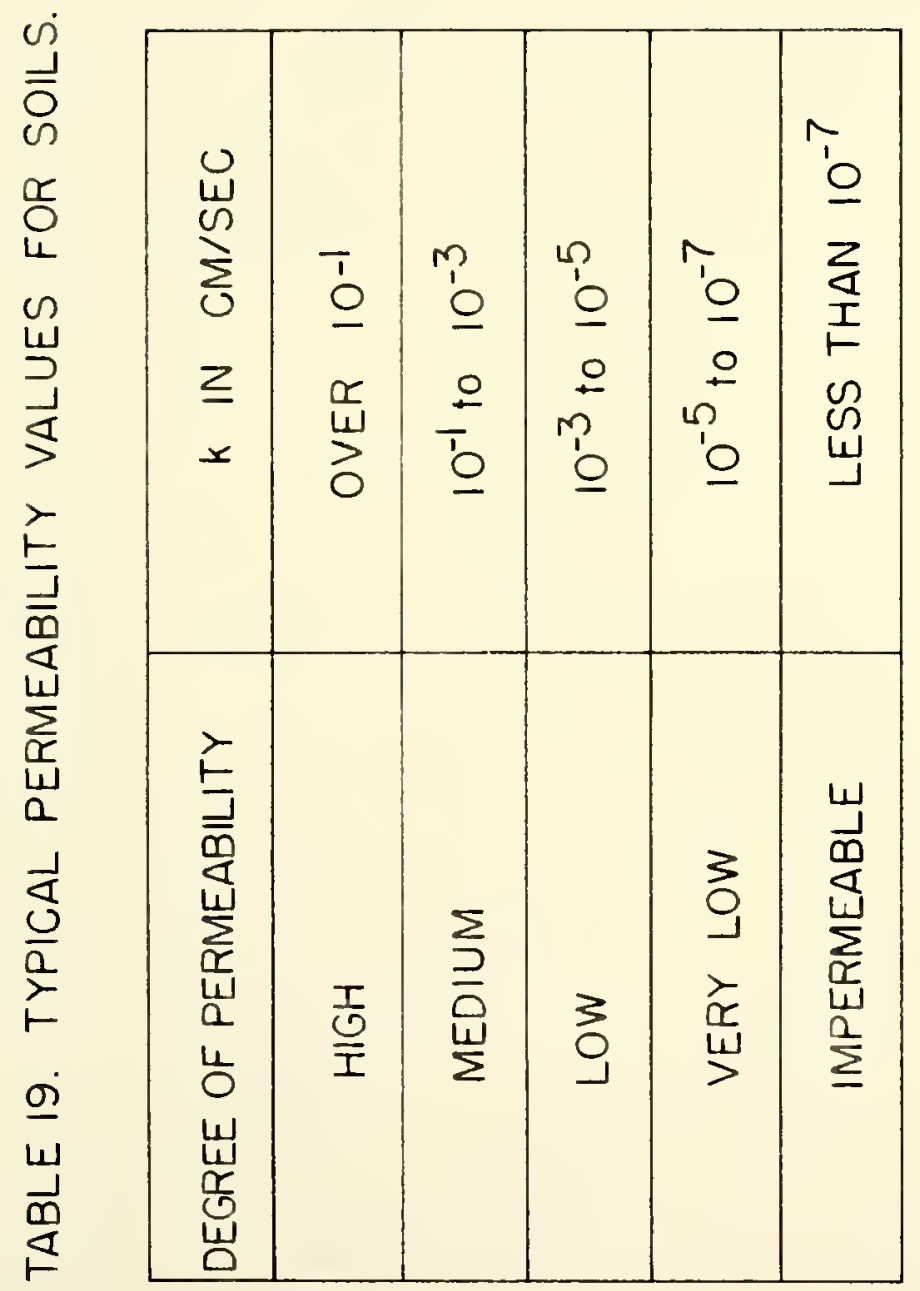




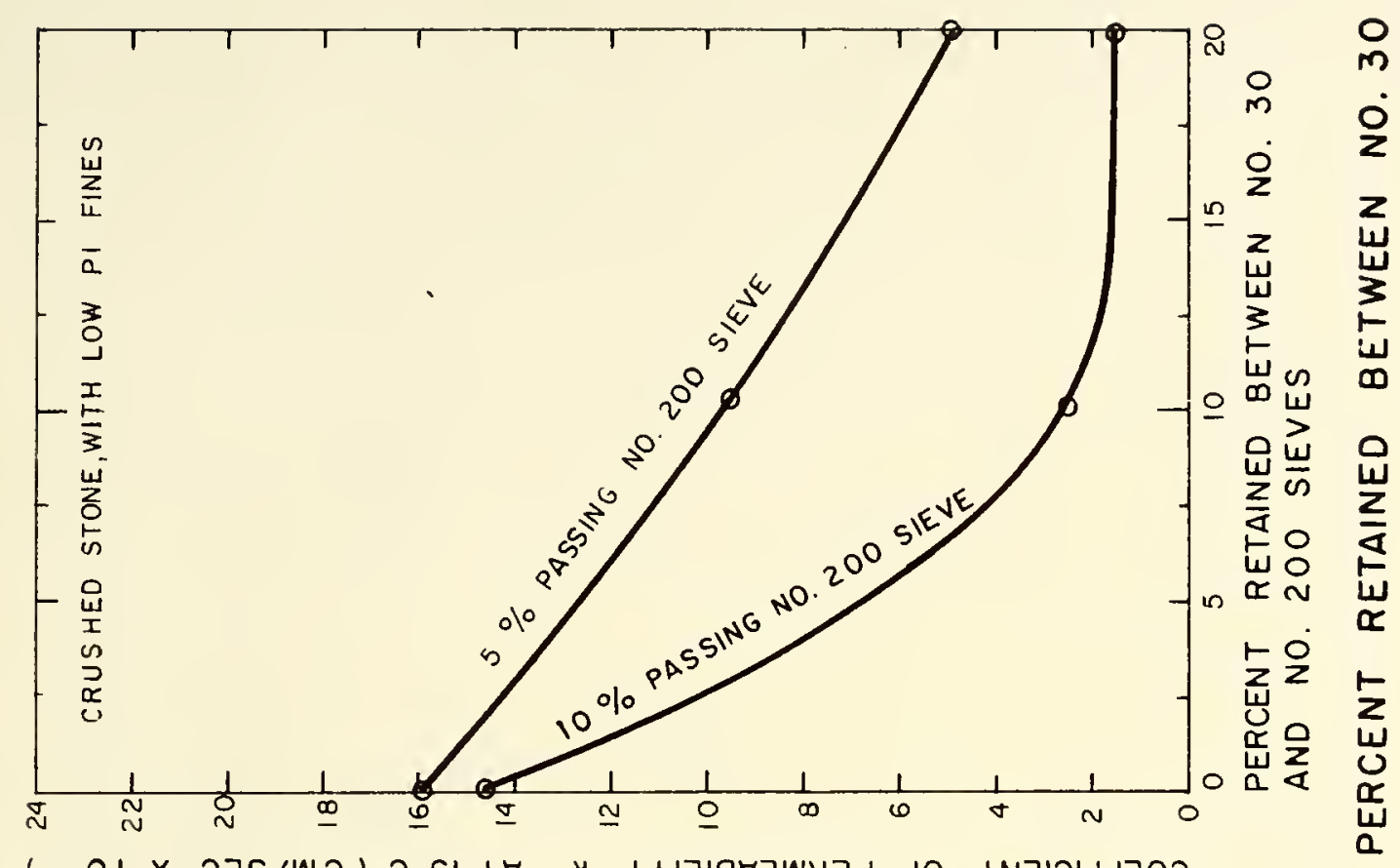

$(b-01 \times$ J

$\frac{I}{3}$

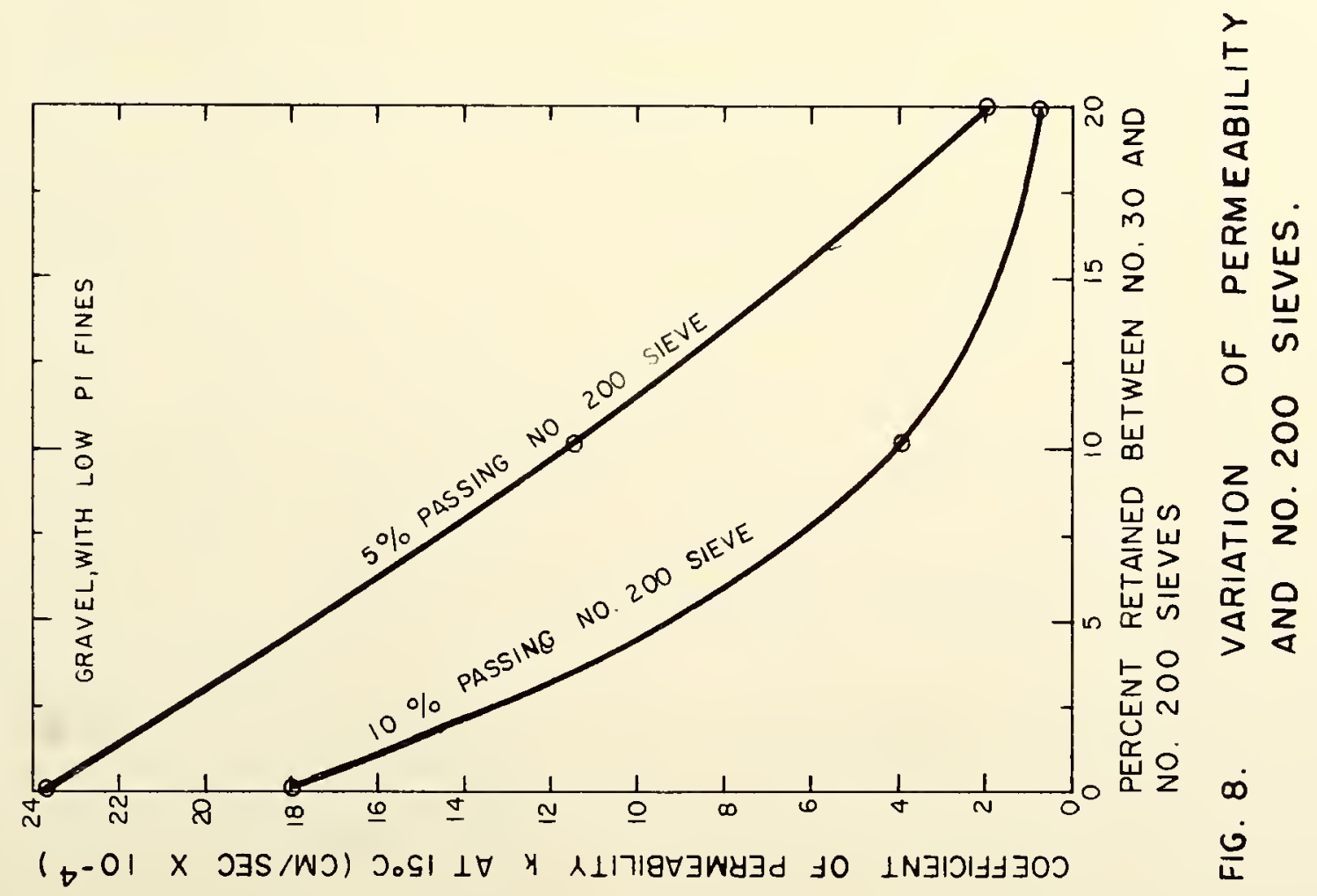


more pronounced in case of mixes with ten percent fines a s opposed to mixes with five percent fines; (d) where mixes were devold of waterial between the No. 30 and No. 200 sieves, gravel mixes showed higher permeability than crushed stone mixes. However, in mixes which were more uniformly graded, crushed stone mixes were more permeable than gravel mixes. The above suggests that skip-grading can improve the permeability characteristics of both crushed stone and gravel mixes. This effect would be of greatest benefit to soilgravel mixes which suffer from a substantial loss in permeability with increase in the omount of material between the No. 30 and No. 200 sieves; (e) using a k-value of $10^{-3} \mathrm{~cm} / \mathrm{sec}$ as the lower limit of coefficlent of permeability would ensure good drainage characteristics in base courses. It is seen from Figure 8 that for mixes with ten percent fines, the percent retalned between the No. 30 and No. 200 sieves should not exceed four percent if gravel aggregates are used and tt should not be over 2.5 percent if crushed stone aggregates are used. For mixes with five percent fines, the percent retafned between the No. 30 and No. 200 sieves should not exceed 12 percent in so11-grave 1 mixes and it should not be over nine percent in case of crushed stone mixes. The above deductions are only volid when low plasticity fines are used ss a binder.

The dust ratios that would provide adequate permeability characteristics are:

1. Gravel, five percent passing No. 200 sieve; dust ratio

$$
>\frac{5}{12+5}=0.29 \text {; }
$$


2. Grave1, ten percent passing No. 200 sieve, dust ratio

$$
>\frac{10}{4+10}=0.71
$$

3. Crushed stone, five percent passing No. 200 sieve, dust ratio

$$
>\frac{5}{9+5}=0.36
$$

4. Crushed stone, ten percent passing No. 200 sieve, dust ratio $>\frac{10}{2.5+10}=0.8$.

\section{A Study of the Interaction of Plasticity and}

\section{Skip-Grading on Strength Characteriatics}

Indiana speclfications for soil-aggregate mixes require that liquid limit and plasticlty index should not exceed 25 percent and five percent respectively.

This analysis indicates that the effect of plasticity on strength depends on the amount of fines (minus No. 200 fraction), the dust ratio, and the plasticity of minus No. 200 fraction. The effect of these factors is outlined as follows:

1. Figure 6 indicates that CBR increases with a decrease in PI when the fines in the soll-aggregate mix are confined to five percent.

2. Figure 7 shows that the effect of PI on CBR becomes less Important as the amount of material between the No. 30 and No. 200 sleves is decreased. This deduction assumes that there are ten percent fines in the soll-aggregate mix.

3. Figures 6 and 7 reveal that irrespective of the percent fines in the mix, soil-aggregate mixtures with low 
plasticity binders have higher strength values as opposed to mixes with high plasticlty binders.

4. The effect of $P I$ on strength is influenced by the interaction of the percent fines in a soil-aggregate mix and the material retained between the No. 30 and No. 200 sieves. Referring to Figure 7 it is seen that a soil-gravel mix with a PI of 9.1 percent and an LL of 29.8 percent gave three times higher CBR values as the soil-gravel mix with an $L L$ of 15.2 percent and no PI. The PI of minus 200 fraction was 9.1 percent in both cases. Thls was due to the fact that the soll-aggregate mlx with a PI of 9.1 percent was skfp-graded between the No. 30 and No. 200 sleves whlle the second mix had 20 percent material in this range. The effect of adding 20 percent sandy material was to make the second mix non-plastic. In the case of the flrst $\mathrm{mLx}$, even though the plasticlty characteristics of the mix made it a substandard material, yet with skipping the material between the No. 30 and No. 200 sieves, it showed supertor strength and drainage characteristics as compared to the materlal with plasticlty parameters within the specifications.

In case of crushed stone and gravel mixes with ten percent high plasticity fines, the same phenomenon is observed. Skip-graded mlxes, though having higher PI values (46.8), showed higher CBR values compared to well-graded mixes which had considerably lower PI values ( 12.8 and 11.9 percent for crushed stone and gravel mixes respectively). 
Figure 6 indicates s soll-gravel mix with five percent high plasticity fines that tested non-plastic owing to the presence of 20 percent material between the No. 30 and No. 200 sieves. According to specifications this would be considered a standard material. However, it gave lower strength values as compared to a substandard soll-gravel mix with a PI of 9.1 percent as shown in Figure 7 . The latter mix had ten percent low PI fines which gave it the better strength characteristics.

Figure 6 shows two crushed stone mixes with 20 percent material retained between the No. 30 and No. 200 siever. Both tested nonplastic. However, one had high plasticity fines (PI $=46.8$ percent, $L I=77.4$ percent), while the other had low plasticity fines (PI = 5.9 percent, $L L=26.4$ percent). According to specifications, both mixes satisfied the plasticity requirements. On testing for $C B R$, the mix with low plasticity fines gave 17 percent higher CBR as compared to the mix with high plasticity fines.

These examples demonstrate the effect of percent fines coupled with the plasticity of minus No. 200 sieve fraction on strength. A complete dependence on plasticity values (PI values of minus No. 40 fraction) may give misleading results. Hence, there is need for developing a criterion for designing soil-aggregate speciflcations that take into consideration the interplay of percent fines in the mix, the dust ratio, and the plasticity characteristics of the mix. It is suggested that plasticity becomes less important if the soil matrix does not f111 the voids in the aggregate. 
CONCLUSIONS

\section{General}

In this study, the stability characteristics of soll-aggregate mixtures were investigated. The factors considered to have an influence on stability were the type of aggregate, the amount of fines in the mix and their plasticity, the fraction retained between the No. 30 and No. 200 sleves, and variation in compaction. The parameters used as a measule of stability were the California Bearing Ratio (CBR), the Texas triaxial compressive strength obtained at a confining pressure of $15 \mathrm{psi}$, the angle of the internal friction measured from the Mohr's envelope, and permeability. The primary objective of this study was to determine the effect of skip-grading the materlal between the No. 30 and No. 200 sieves on the stability of soil-gravel and soil-crushed stone mixes. The conclusions that follow apply to the type of materials and test methods used in this study.

1. In general, the crushed stone mixtures resulted in higher teat values than the gravel mixtures. The soil-gravel mixes indicated a Texas triaxial class between 3.4 and 4.0, whereas the soil-crushed stone mixtures showed a range of 1.0 to 2.6 .

2. The soil-aggregate mixes with low plasticity fines tested at higher strength values, compared to mixes with high plasticity fines. 
3. As expected, soil-aggregate mixes compacted at 50 percent of the standard compactive effort tested at a lower CBR than mixes compacted at 100 percent standard compactive effort (56-blow compaction). The densities for the lower compactive effort varied from 93 percent to 99 percent of the densities obtained with the 56-blow compaction. The percentage decrease in density observed by a given decrease in compactive effort was a function of the grading of the mix. In case of skip-graded and lean mixes, the amount of breakage affected the compactability of the mix, whereas in the richer and better graded mixes the compaction characteristics were controlled by the amount of fines in the mix.

4. Crushed stone mixes with non-plastic fines tested at approximately the same compressive strengths as mixes with low plasticity fines.

5. The effect of plasticity on strength characteristics of a soil-aggregate mix depended to a great degree on the amount of fines in the mix. When the fines in the mixes were restricted to a minimal amount, compatible with the stability of the mix, then the effect of plasticity became less significant. Similarly, with adequate fines and skipgrading of the material between the No. 30 and No. 200 sieves, the soil-gravel mixes showed adequate strength characteristics though the plasticity characteristics were 
above the prescribed upper limits of plasticity index and liquid limit.

6. Crushed stone mixtures, in general, showed higher permeabilities than gravel mixtures. However, in the case of skip-graded mixes, devold of material between the No. 30 and No. 200 sieves, the gravel mixes showed higher permeability than the crushed stone mixes.

\section{Eifect of Skip-Grading Between the}

No. 30 and No. 200 Sieves

Table 20 summarizes the results relating to the effect of skipgrading on stability and permeability of the soil-aggregate mixtures. This table shows the limiting values of dust ratio and percent passing the No. 30 mesh sieve for certain criteria given in the first column of the table. The values apply to the tested mixtures with low plasticity, fines. A permeability of $10^{-3} \mathrm{~cm} / \mathrm{sec}$ was considered to be the borderline between medium and low permeabilities. It was further assumed that soil-aggregate mixes exhibiting a permeability of less than $10^{-3} \mathrm{~cm} / \mathrm{sec}$ would have poor drainage characteristics. A CBR of 80 percent was considered to be a measure of adequate strength characteristics. Triaxial criteria used stated that the material must have a minimum angle of internal friction of $50^{\circ}$ and also a minimum strength of 175 psi at 15 psi lateral confining pressure. This is compatible with Texas Grade 1 base material. 


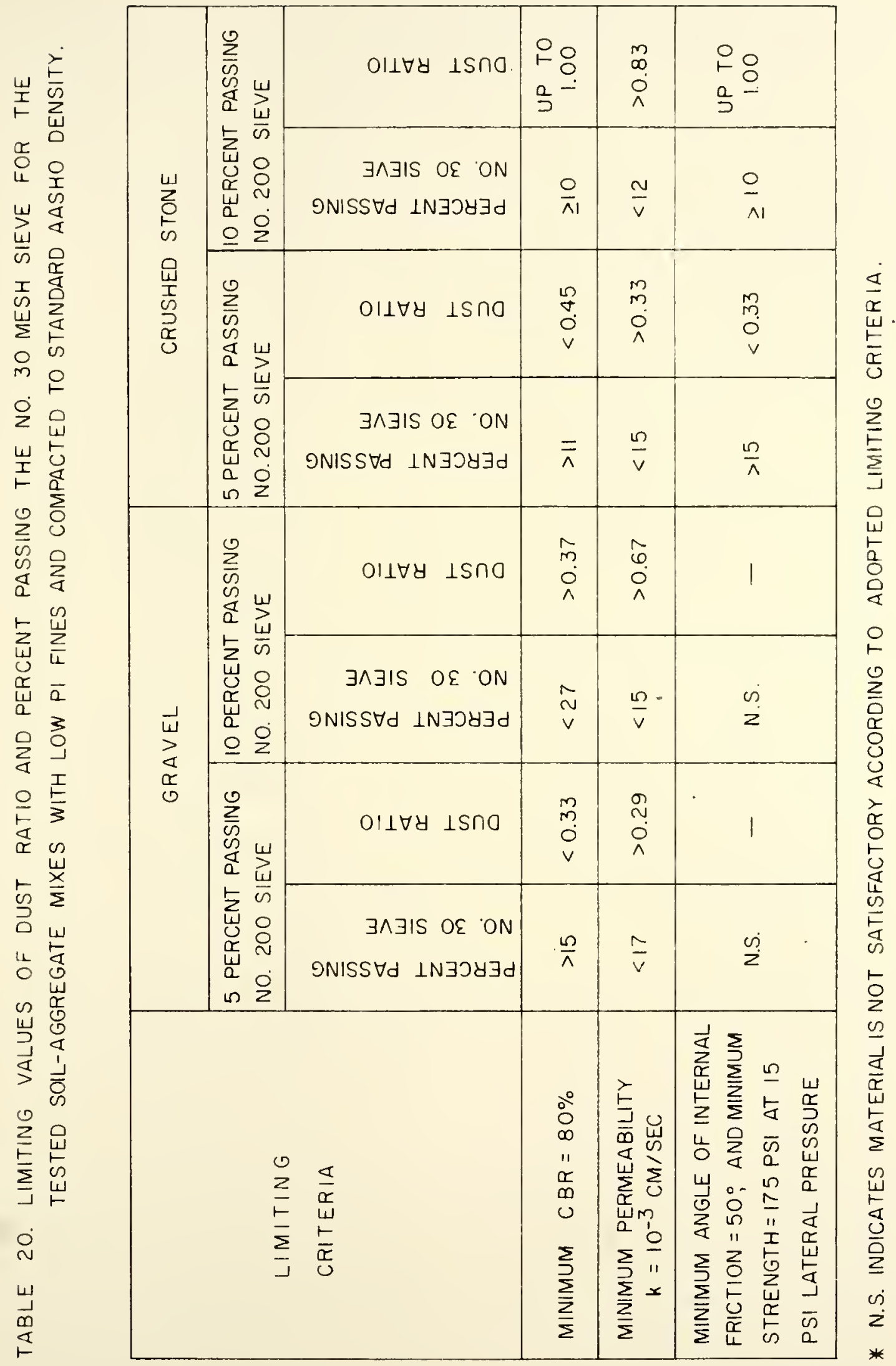


On the basis of tests reported herein the following statements can be made:

1. The fraction retained between the No. 30 and No. 200 sieves had a significant influence on both strength and permeabil1ty characteristics of soil-aggregate mixtures. However, the variation of strength and permeability parameters with the fraction retained between the No. 30 and No. 200 sieves was a function of the percent fines in the mix.

2. Skip-grading of the fraction between the No. 30 and No. 200 sieves was harmful in case of soil-aggregate mixes with only five percent fines in the mit.

3. In case of soil-gravel mixes with ten percent fines, skip= grading of the fraction between the No. 30 and No. 200 siever improved the strength and permeablitity characteristics considerably. The crushed stone mixes with ten percent passing the No. 200 sieve showed excellent strengths irregpective of the amount of material retained between the No, 30 and No. 200 sieves.

4. In order to ensure adequate strength, (a) gravel mixes with five percent fines should have more than 15 percent material passing the No. 30 sieve (a dust ratio of less than 0.33 ); (b) grave 1 mixes with ten percent fines should have less than 27 percent material passing the No. 30 sieve (dust ratio greater than 0.37 ); (c) crushed stone mixes with five percent fines ahould have more than 11 percent passing 
the No. 30 sieve (dust ratio less than 0.45); (d) crushed stone mixes with ten percent fines may have as little as ten percent passing the No. 30 sieve (dust ratio up to $1.00)$

5. In order to ensure adequate drainage characteristics, (a) gravel mixes with five percent fines should have less than 17 percent material passing the No. 30 sleve (dust ratio greater than 0.29); (b) gravel mixes with ten percent fines should have less than 15 percent material passing the No. 30 sieve (dust ratio greater than 0.67 ); (c) crushed stone mixes with five percent fines should have less than 15 percent material passing the No. 30 sieve (dust ratio greater than 0.33); (d) crushed stone mixes with ten percent fines may have as little as ten percent materlal passing the No. 30 sieve (dust ratlo up to 1.00 ). 
BIBL IOGRAPHY 


\section{BIBL IOGRAPHY}

1. AASHO, "Highway Materials, Part II, Testa", 9th Edition, 1966.

2. A \& H Engineering \& Testing Corp., "Physical Properties of Illinols Aggregate Affecting Load Bearing Strength and Performance!", Illinois Association of Aggregate Producers, 1969.

3. ASTM, "Procedures for Testing Solls", 4th Edition, December, 1964.

4. Barber, E. S., and Sawyer, C. L., "Highway Subdralnage", Proceedings, Highway Research Board, 1952.

5. Bureau of Public Roads, "Aggregate Gradation: Simplification, Standardization, and Unfform Application", U. S. Government Printing office, 1962 .

6. Burr, I. W., "Engineering Statistics and Quality Control", Appendix, Table D, p. 409, McGraw-Hill, 1953.

7. Carpenter, C.A., and Willis, E. A., "A. Study of Sand Clay Materials for Base Course Construction", Public Roads, Vol. 19, No. 9, November, 1938.

8. Carpenter, C. A., and Willis, E. A., "A Study of Sand-ClayGravel Mixtures for Base Course Construction", Public Roads, Vol. 20, No. 1, March, 1939.

9. Chamberlain, W. P., and Yoder, E. J., "Effect of Base Course Gradation on Results of Laboratory Pumping Tests", Highway Research Board, Bulletin 202, 1958.

10. Deklotz, L. A., "Effect of Varying the Quantity and Quality of the Soil Portion of Highway Aggregate on Their Stability", Proceedings, Highway Research Board, 1940.

11. Gray, J. E., "Investigation of Properties of Dense Graded Base Course Aggregates", National Crushed Stone Association, October, 1961.

12. Hogentogler, C. A., and W1llis, E. A., "Stabilized Soil Roads", Public Roads, Vol. 17, No. 3, May, 1936. 
13. Indiana State Highway Commission, "Standard Specifications", 1969.

14. Lambe, T. W., "Soll Testing for Engineers", John Wiley and Sons, Inc., 1951.

15. Materials and Tests Division, "Test Limits for a Unified Base Material Specification", Presented at the 5th Annual Meeting of District Laboratory Engineers, Texas Highway Department, October, 1960. Unpublished.

16. McDowe11, C., "Comparison of AASHO and Texas Test Methods and Specifications for Flextble Base Material", HPR-1 Research Project No. 1-9-63-48, Conducted by Materis1s and Tests Division, Soil Section, Texas State Highway Department, May, 1966.

17. Ostle, B., "Statistics in Research", Iowa State University Press, 1963.

18. Townsend, D. L., and Mad111, J. W., "The Effect of Crushed Particles on the Strength of Base Course Materials", Queen's University, Kingston, Ontario, August, 1964.

19. Yoder, E. J., "Principles of Pavement Design", pp. 283-314, John Wiley and Sons, Inc., 1959.

20. Yoder, E. J., and Lowrie, C. R., "Triaxial Testing Applied to Design of Flexible Pavementa", Proceedings, Highway Research Board, 1952 .

21. Yoder, E. J., and Woods, K. B., "Compaction and Strength Characteristics of Soil-Aggregate Mixtures", Proceedings, Highway Research Board, 1947. 



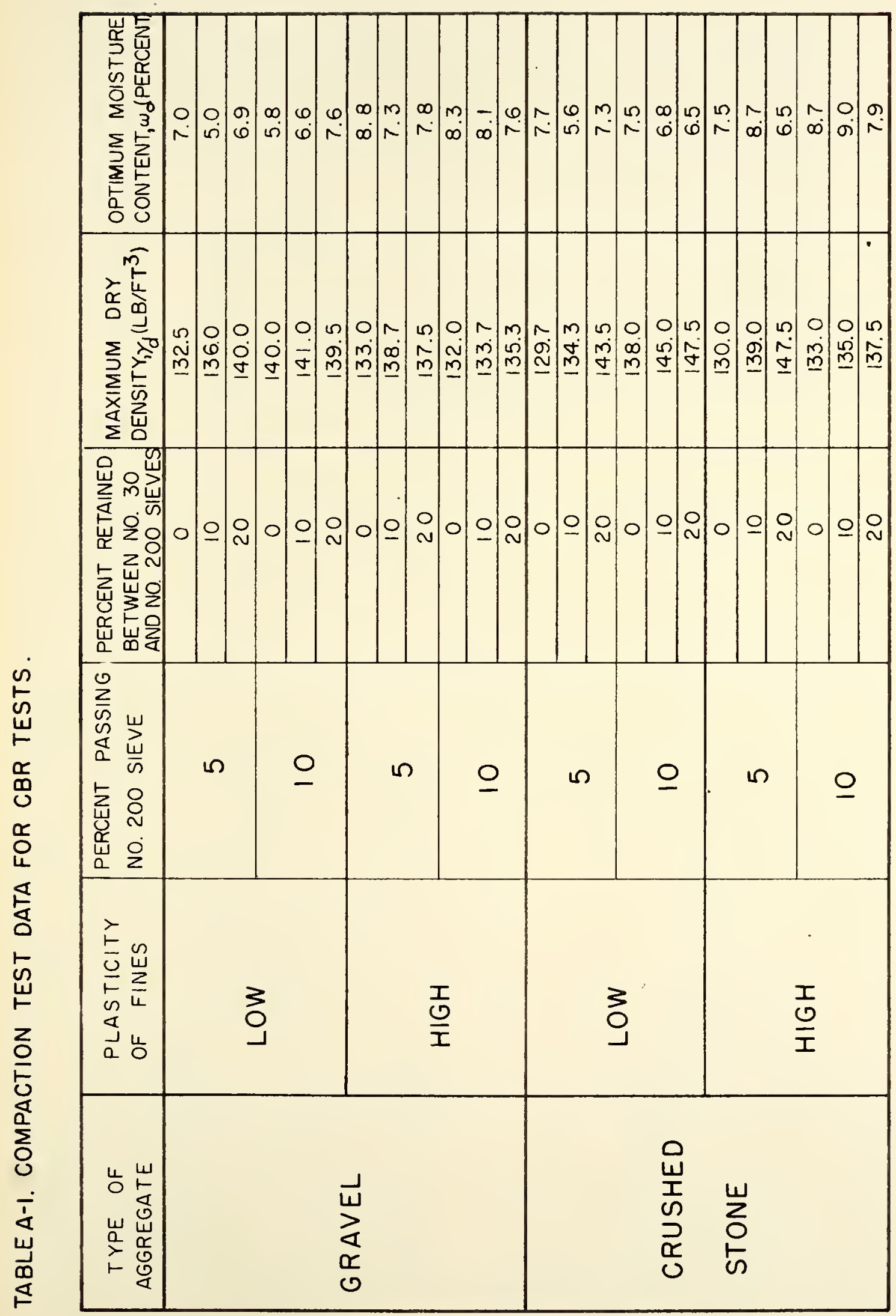




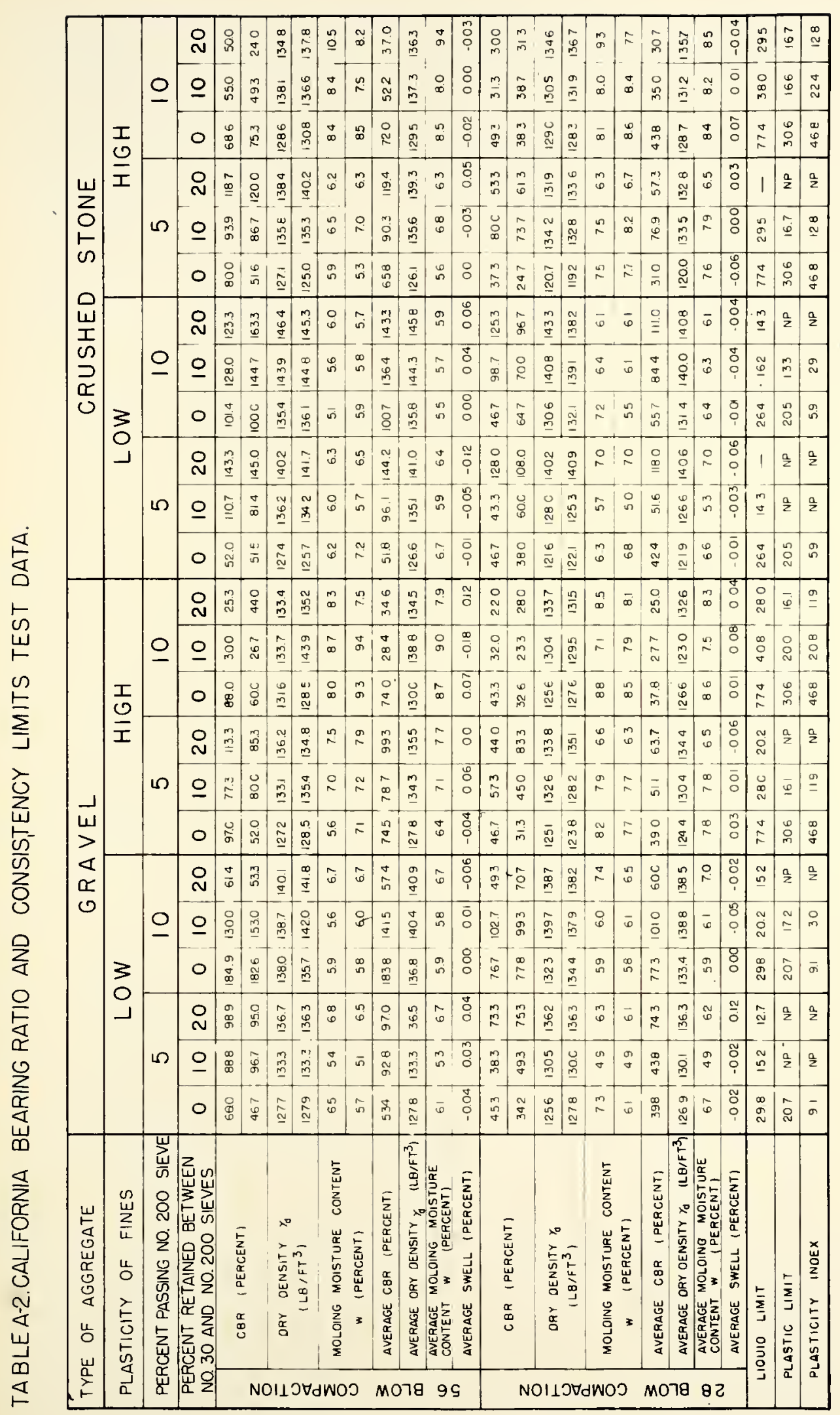




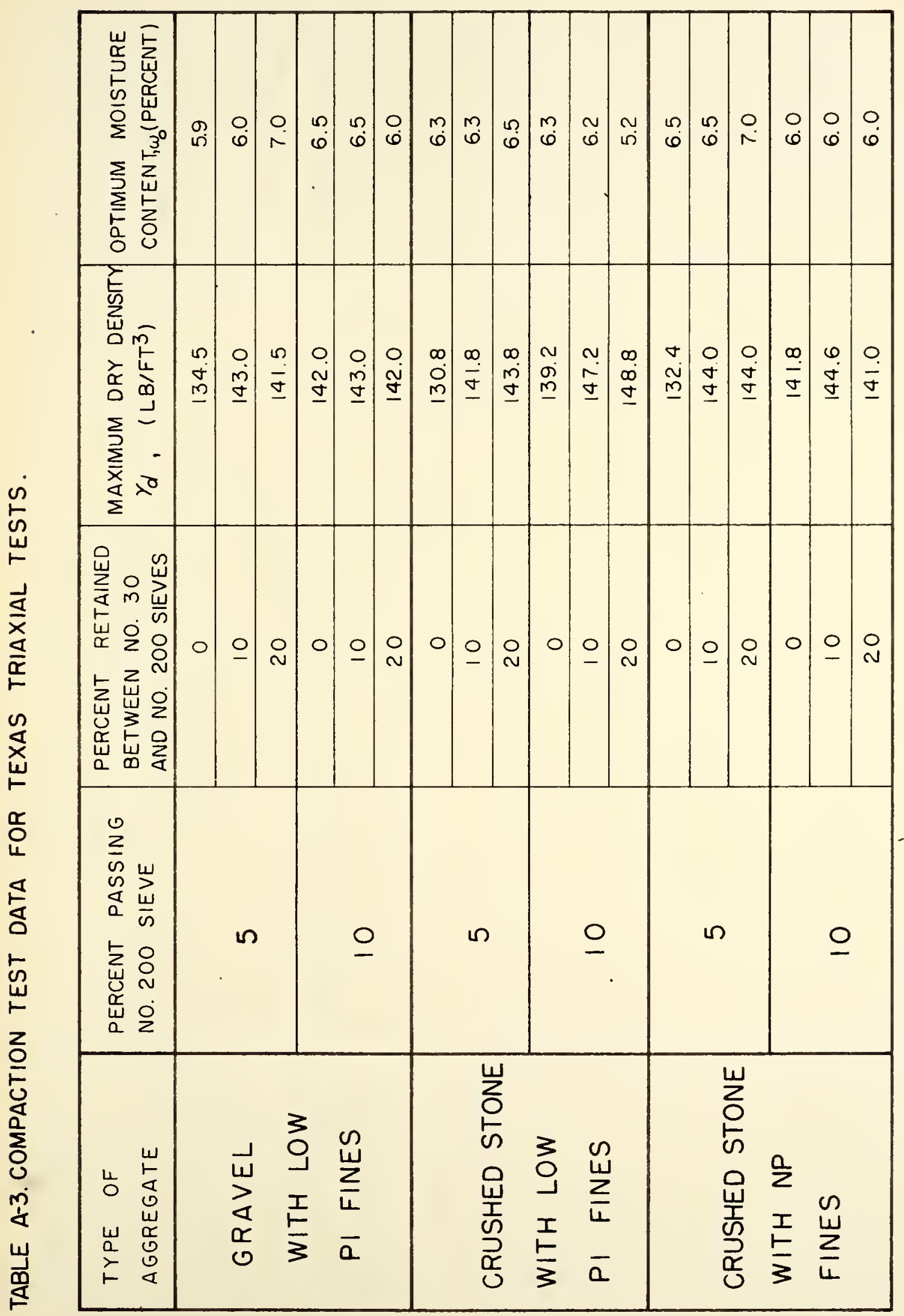




\begin{tabular}{|c|c|c|c|c|c|c|c|c|c|}
\hline \multirow{6}{*}{ 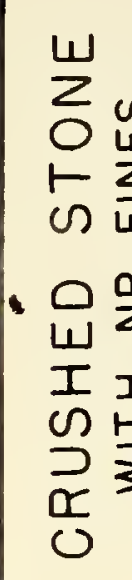 } & \multirow{6}{*}{$\begin{array}{l}n \\
\frac{U}{Z} \\
\frac{n}{Z} \\
I \\
\frac{1}{3}\end{array}$} & \multirow{3}{*}{$\underline{0}$} & $\begin{array}{l}0 \\
N\end{array}$ & 8 & $\frac{m}{6}$ & $\begin{array}{l}\varphi \\
i \\
ن\end{array}$ & 1 & 足 & $\frac{a}{z}$ \\
\hline & & & $\underline{-}$ & 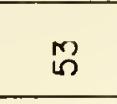 & $\frac{\dot{\sigma}}{N}$ & 으. & 1 & $\frac{a}{2}$ & $\frac{a}{2}$ \\
\hline & & & 0 & 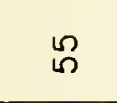 & $\stackrel{\infty}{\stackrel{\infty}{\mathrm{N}}}$ & $\begin{array}{l}\varphi \\
\dot{v}\end{array}$ & 1 & $\frac{a}{z}$ & $\frac{a}{2}$ \\
\hline & & \multirow{3}{*}{ תا } & $\begin{array}{l}0 \\
N\end{array}$ & 오 & $\begin{array}{l}\infty \\
\stackrel{\infty}{\tilde{O}} \\
\stackrel{N}{N}\end{array}$ & $\underline{0}$ & 1 & 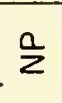 & $\frac{a}{z}$ \\
\hline & & & $\underline{0}$ & L & $\stackrel{8}{\mathbb{N}}$ & $\stackrel{n}{m}$ & 1 & 吕 & $\frac{a}{z}$ \\
\hline & & & 0 & $\stackrel{v}{\sigma}$ & $\stackrel{m}{\stackrel{m}{\mathrm{~N}}}$ & $\begin{array}{l}\mathscr{\omega} \\
\stackrel{\sim}{\sim}\end{array}$ & 1 & $\frac{a}{z}$ & $\frac{a}{2}$ \\
\hline \multirow{6}{*}{$\begin{array}{l}w \\
z \\
0 \\
u \\
0 \\
0 \\
w \\
\frac{1}{0} \\
\frac{\alpha}{0}\end{array}$} & \multirow{6}{*}{$\begin{array}{l}w \\
w \\
\frac{2}{4} \\
\bar{a} \\
3 \\
0 \\
1 \\
\frac{1}{3}\end{array}$} & \multirow{3}{*}{$\underline{0}$} & $\begin{array}{l}0 \\
\mathbf{N}\end{array}$ & 芴 & $\frac{\sigma}{\sim}$ & $\stackrel{\sim}{\sim}$ & $\stackrel{m}{\dot{v}}$ & $\frac{a}{z}$ & $\frac{a}{2}$ \\
\hline & & & $\underline{0}$ & 络 & $\begin{array}{l}\stackrel{\sigma}{\sigma} \\
\stackrel{\sigma}{\sigma}\end{array}$ & N & $\begin{array}{l}\stackrel{v}{\varphi} \\
\underline{\varphi}\end{array}$ & $\dot{m}$ & \% \\
\hline & & & 0 & 苾 & $\stackrel{m}{a}$ & in & $\stackrel{\nabla}{\mathscr{O}}$ & 吕 & \% \\
\hline & & \multirow{3}{*}{$1 \Omega$} & $\begin{array}{l}0 \\
N\end{array}$ & $\begin{array}{l}0 \\
0\end{array}$ & \begin{tabular}{l}
0 \\
$\infty$ \\
\multirow{2}{+}{} \\
$\sim$
\end{tabular} & $\underset{\sim}{\sim}$ & 1 & $\frac{a}{z}$ & $\frac{a}{2}$ \\
\hline & & & $\underline{0}$ & กี & $\stackrel{\nabla}{\stackrel{\theta}{\Sigma}}$ & $\bar{n}$ & $\stackrel{m}{\dot{m}}$ & 况 & $\frac{a}{2}$ \\
\hline & & & 0 & น & $\begin{array}{l}\infty \\
\stackrel{0}{0} \\
\end{array}$ & $\stackrel{\omega}{\omega}$ & \begin{tabular}{l}
\multirow{\sigma}{0}{} \\
$\sim$
\end{tabular} & $\begin{array}{l}n \\
0 \\
\sim\end{array}$ & ब) \\
\hline \multirow{6}{*}{$\begin{array}{l}1 \\
w \\
\alpha \\
\alpha \\
0\end{array}$} & \multirow{6}{*}{$\begin{array}{l}w \\
w \\
\frac{2}{4} \\
\bar{a} \\
3 \\
5 \\
\pm \\
\frac{1}{3}\end{array}$} & \multirow{3}{*}{$\underline{0}$} & $\begin{array}{l}0 \\
N\end{array}$ & $\hat{m}$ & $\begin{array}{l}\varphi \\
0 \\
0\end{array}$ & $\stackrel{O}{\sigma}$ & กี & 을 & $\frac{a}{2}$ \\
\hline & & & $\stackrel{0}{-}$ & $\stackrel{m}{\sigma}$ & ñ & $\hat{m}$ & $\underset{\sim}{\stackrel{O}{O}}$ & $\stackrel{N}{N}$ & $\frac{0}{m}$ \\
\hline & & & 0 & $\underset{\sim}{\infty}$ & . & $\stackrel{n}{m}$ & $\stackrel{\infty}{\stackrel{\infty}{\sim}}$ & $\hat{\circ}$ & $\bar{\sigma}$ \\
\hline & & \multirow{3}{*}{ תا } & $\stackrel{O}{N}$ & $\tilde{\sigma}$ & $\stackrel{+}{\stackrel{H}{0}}$ & $\dot{\sigma}$ & $\tilde{\underline{u}}$ & $\frac{n}{2}$ & $\frac{a}{2}$ \\
\hline & & & $\underline{0}$ & N & $\stackrel{N}{\stackrel{N}{*}}$ & $\hat{m}$ & Nָ & $\frac{a}{z}$ & $\frac{a}{2}$ \\
\hline & & & $\bigcirc$ & $\bar{n}$ & $\frac{0}{m}$ & $\stackrel{\infty}{m}$ & ๙̊ & $\hat{o}$ & $\bar{\sigma}$ \\
\hline $\begin{array}{l}4 \\
0 \\
w \\
2\end{array}$ & 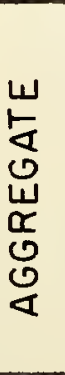 & 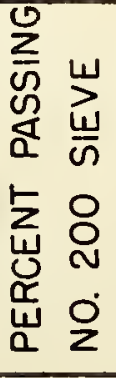 & 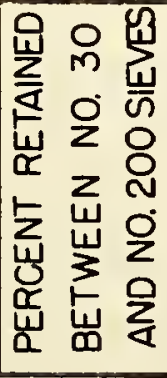 & 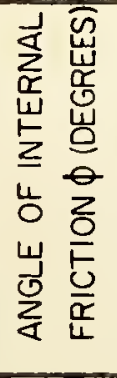 & 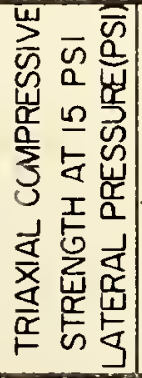 & 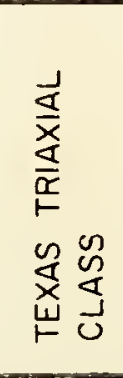 & $\begin{array}{l}\text { 上 } \\
\underline{\Xi} \\
\stackrel{0}{\bar{J}} \\
\frac{\mathrm{g}}{J}\end{array}$ & 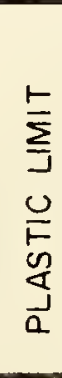 & 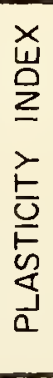 \\
\hline
\end{tabular}




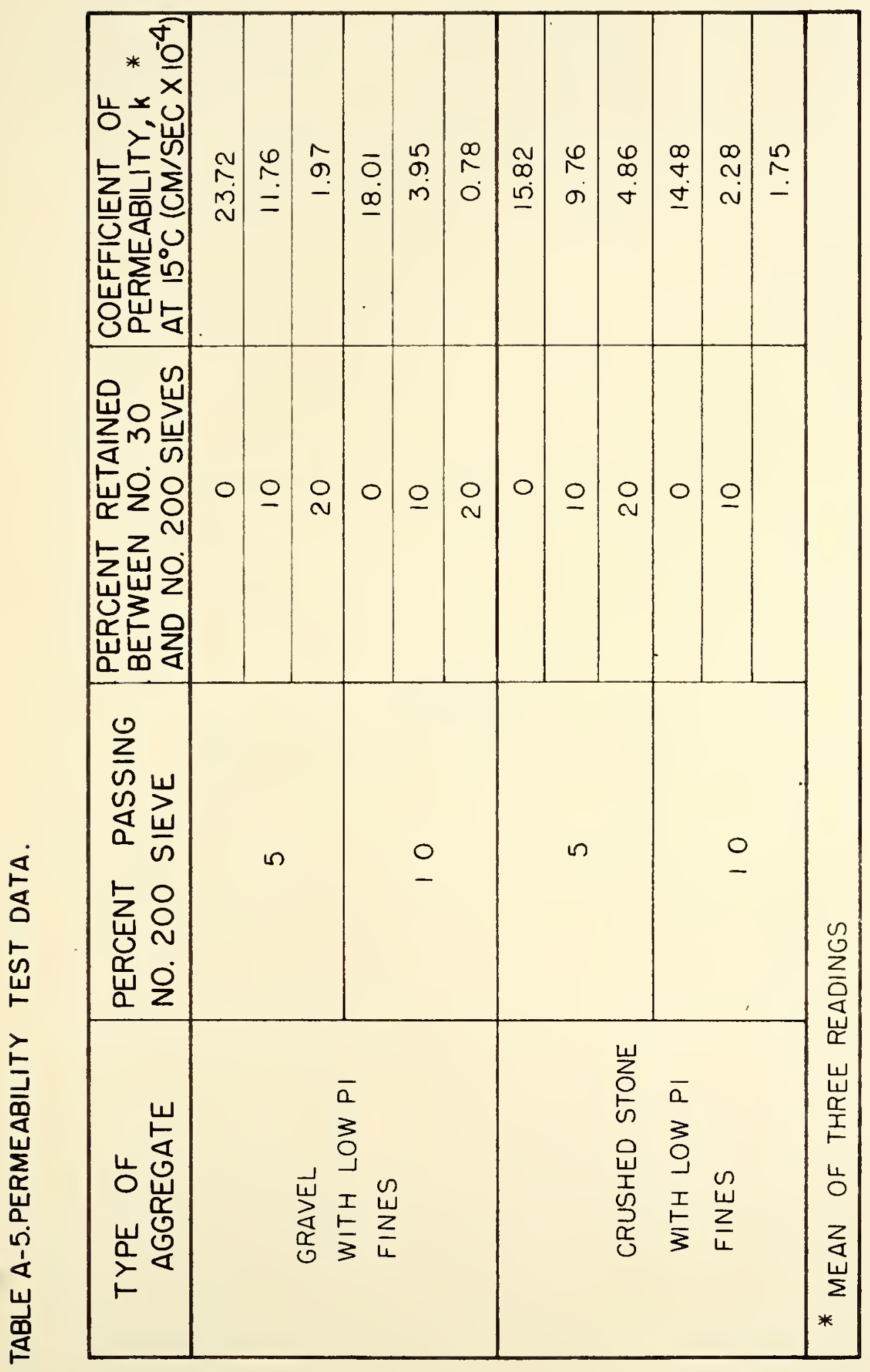


APPENDIX B

EQUATIONS OF BEST FIT FOR CBR TEST DATA 


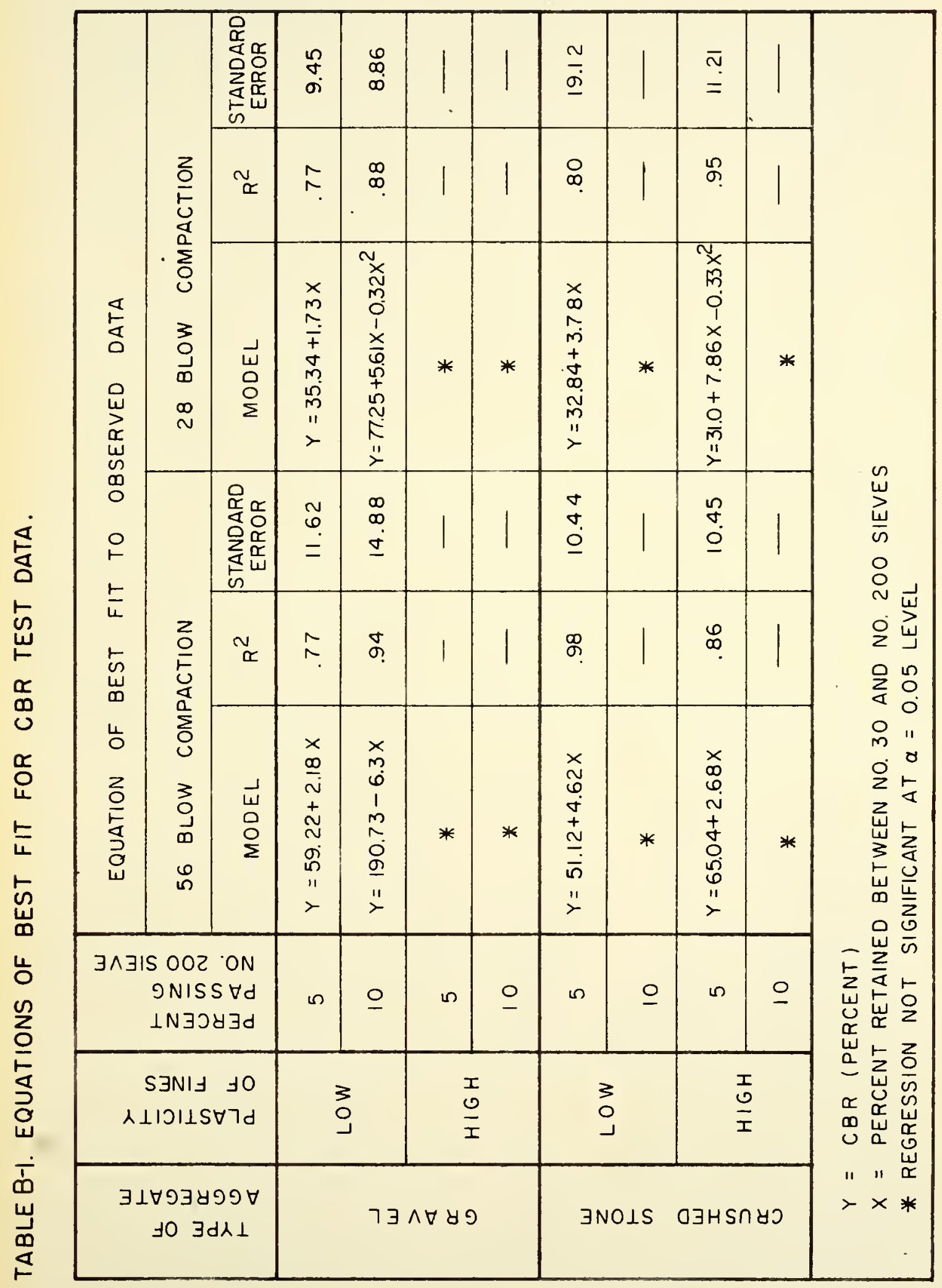



